\title{
MERCADOS DE TRABALHO FORMAL E INFORMAL: UMA ANÁLISE DA DISCRIMINAÇÃO E DA SEGMENTAÇÃO
}

\section{NANCY DE DEUS VIEIRA SILVA}

Bacharel em Ciências Econômicas

Orientadora: Profa. Dra. ANA LÚCIA KASSOUF

Dissertação apresentada à Escola Superior de Agricultura "Luiz de Queiroz", Universidade de São Paulo, para obtenção do título de Mestre em Ciências, Área de Concentração: Economia Aplicada.

\section{PIRACICABA}

Estado de São Paulo - Brasil

Julho -1997 
Dados Internacionais de Catalogação na Publicação (CIP)

DIVISÃO DE BIBLIOTECA E DOCUMENTAÇÃO - Campus "Luiz de Queiroz"/USP

Silva, Nancy de Deus Vieira

Mercados de trabalho formal e informal : uma análise da discriminação e da segmentação / Nancy de Deus Vieirá Silva. . - Piracicaba, 1997.

$137 \mathrm{p}$.

Dissertação (mestrado) - - Escola Superior de Agricultura Luiz de Queiroz, 1997. Bibliografia.

1. Brasil 2. Discriminação no emprego 3. Mercado de trabalho 4. Rendimento I. Título

CDD 331.12 


\section{MERCADOS DE TRABALHO FORMAL E INFORMAL: UMA ANÁLISE DA DISCRIMINAÇÃO E DA SEGMENTAÇÃO}

Aprovada em: 05.09.1997

Comissão julgadora:

Profa. Dra. Ana Lúcia Kassouf

ESALQ/USP

Prof. Dr. Reynaldo Fernandes

FEA/USP

Prof. Dr. Geraldo Sant'Ana de Camargo Barros

Profa. Dra. ANA LÚCIA KASSOUF Orientadora 
Dedico

Ao Edivaldo, meu marido,

Pelo seu amor, compreensão, $e$ apoio a todo momento.

À Nadir e Adésio, meus pais.

Pelo seu exemplo de vida e pela minha formação.

À Deus,

Por ter me abençoado pela existência de pessoas tão magnificas em minha vida. 


\section{AGRADECIMENTOS}

À Profa. Ana Lúcia Kassouf, que me orientou com segurança e dedicação, a quem atribuo grande parcela do sucesso desta fase da minha formação. A ela não somente meus agradecimentos, mas também minha completa admiração pelo seu trabalho exemplar. Aos senhores membros da banca, Prof. Dr. Geraldo Sant'Ana de Camargo Barros e Prof. Dr. Reynaldo Fernandes pelas valiosas críticas e sugestões que contribuíram para o aprimoramento do presente trabalho. Agradeço também ao Prof. Dr. Paulo Fernando Cidade de Araújo e ao Prof. Dr. Carlos José Caetano Bacha pelas sugestões que em muito contribuíram na elaboração desta dissertação.

Ao Departamento de Economia e Sociologia Rural que me proporcionou a oportunidade deste aperfeiçoamento e pelas condições de trabalho oferecidas para a realização desta dissertação. Meus agradecimentos também a todos os professores e funcionários do Departamento que direta ou indiretamente contribuíram na minha formação.

À Fundação de Amparo à Pesquisa do Estado de São Paulo (FAPESP), por me prover recursos financeiros para concluir com sucesso o curso de mestrado e pelo financiamento para a publicação da forma final deste trabalho. À Coordenadoria de Aperfeiçoamento de Pessoal de Nível Superior (CAPES), pelo auxílio financeiro.

Ao Departamento de Economia da Universidade Federal de Uberlândia, pela formação de "Bacharel em Ciências Econômicas". Um agradecimento especial ao Prof. Dr. José Diniz de Araújo, pela sua amizade e incentivo.

A todos os colegas e grandes amigos do curso de pós-graduação, pela amizade, companheirismo e estímulo.

Finalmente, expresso minha sincera gratidão, respeito e admiração à minha família, especialmente aos meus irmãos: Edlamar, Ernane, Edmar, Meire, Neide e Jairo, por sua cumplicidade, paciência, compreensão e carinho. 


\section{SUMÁRIO}

Página

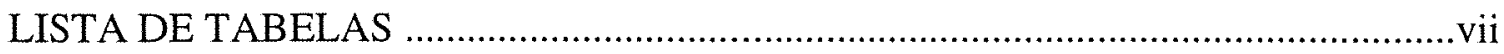

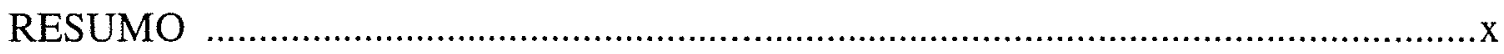

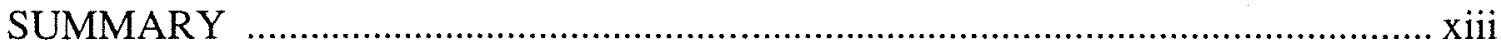

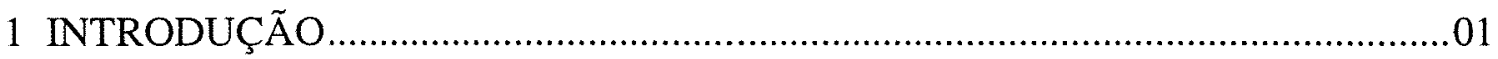

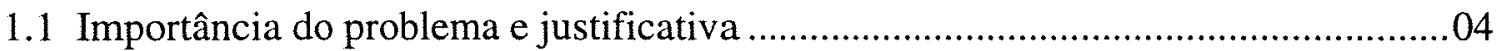

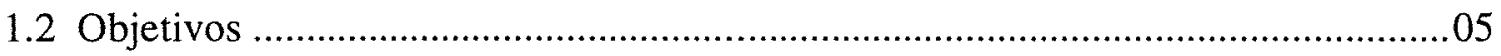

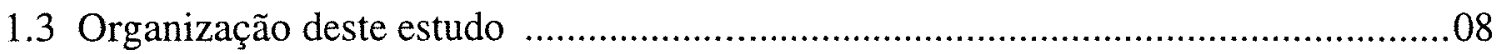

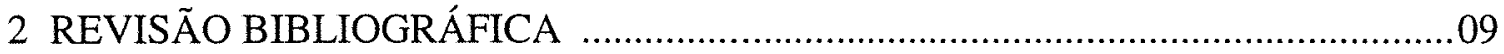

2.1 As controvérsias sobre o conceito de setor informal .................................................

2.1.1 O Relatório do Quênia e a origem do setor informal .............................................10

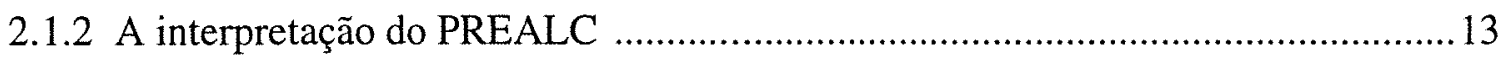

2.1.3 A abordagem subordinada e intersticial ...........................................................17

2.1.4 O enfoque da economia subterrânea ………………………………………...21

2.1.5 A interpretação de mercado de trabalho informal usualmente adotada

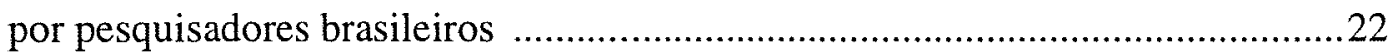

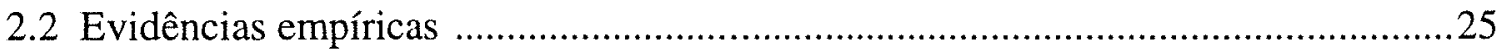

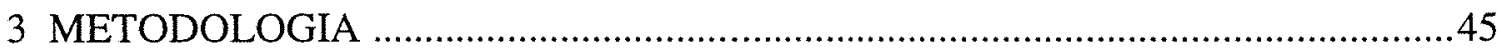

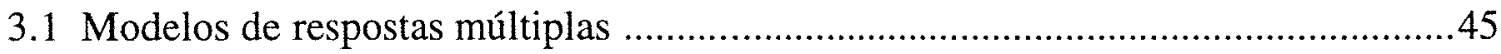

3.1.1 Modelo de respostas múltiplas com seletividade amostral ..................................45

3.1.2 Efeitos Marginais no modelo lógite multinomial ……………............................49

3.2 O efeito da discriminação e da segmentação do mercado de trabalho

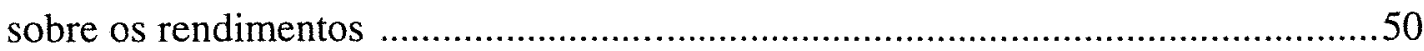

3.2.1 Rendimentos potenciais dos grupos em desvantagem ......................................54

3.3 Operacionalização dos mercados de trabalho formal e informal neste estudo .........55

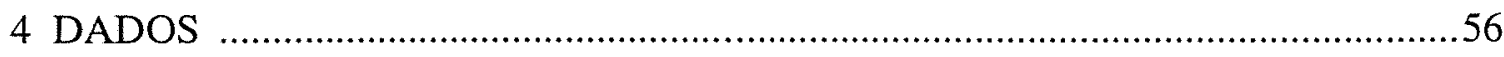




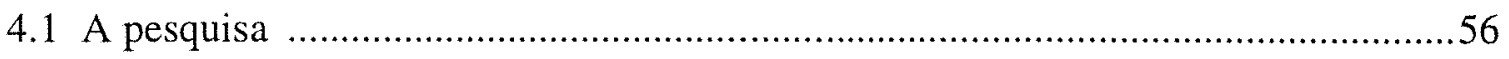

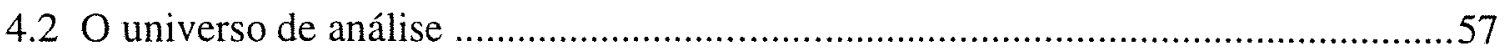

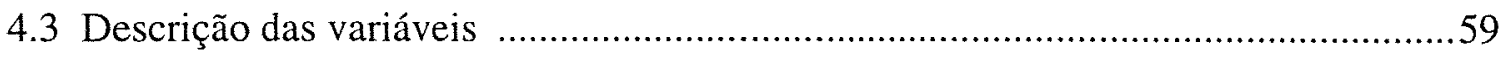

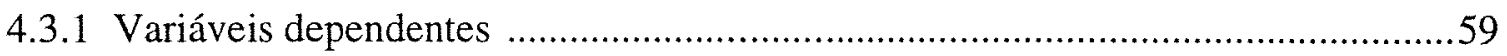

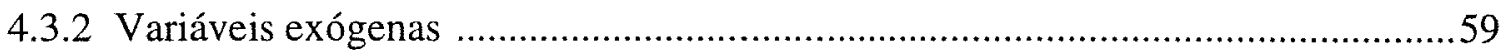

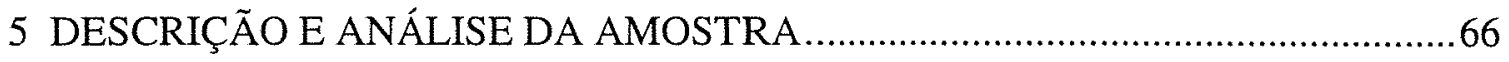

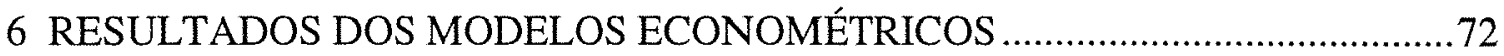

6.1 Os determinantes da participação da força de trabalho nos mercados de trabalho formal e informal e para empregadores ....................................................72

6.2 Funções de rendimentos para os setores formal e informal e para empregadores ..85

6.2.1 Retornos à experiência e à escolaridade ...........................................................93

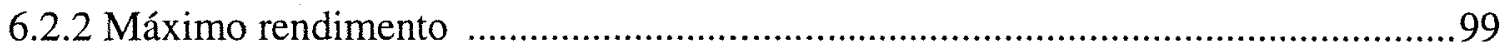

$6.3 \mathrm{O}$ efeito da discriminação por gênero sobre os rendimentos ...................................102

$6.4 \mathrm{O}$ efeito da segmentação por mercado de trabalho, formal e informal, sobre

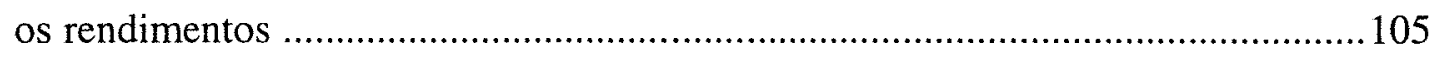

$6.5 \mathrm{O}$ efeito da discriminação racial sobre os rendimentos ............................................109

7 SÍNTESE DOS PRINCIPAIS RESULTADOS OBTIDOS NAS EQUAÇÕES

DE PARTICIPAÇÃO E DE RENDIMENTOS ..................................................113

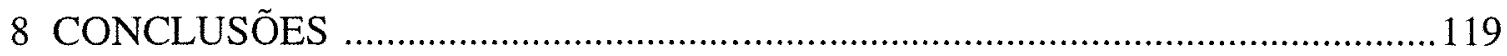

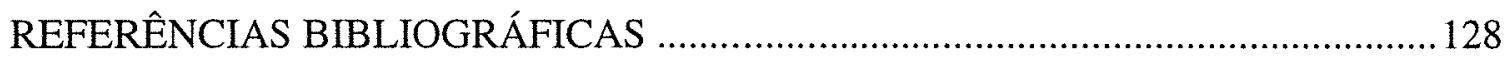

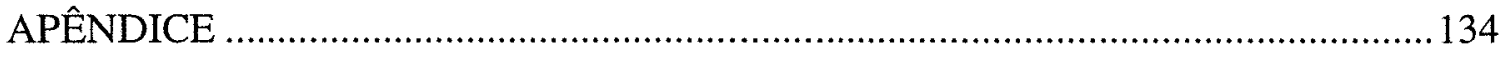




\section{LISTA DE TABELAS}

Página

1 Composição da força de trabalho brasileira por posição na ocupação - 1991/95, em porcentagem. Empregado com carteira de trabalho assinada (CC), empregado sem carteira de trabalho assinada (SC), trabalhadores por conta própria (CP), empregadores (EMP),............................................................. 26

2 Diferenciais de salário total e diferencial de salário inexplicado em El Salvador (1990), Peru (1986) e México (1990).

3 Composição da força de trabalho brasileira por categoria em 1995, para trabalhadores com idade entre 25 e 65 anos residentes no setor urbano.

4 Descrição das variáveis utilizadas nas equações de participação, médias e desvios padrões, para homens e mulheres nos setores formal e informal e para empregadores

5 Descrição das variáveis utilizadas nas equações de rendimentos, médias e desvios padrões, para homens e mulheres nos setores formal e informal e para empregadores.

6 Participação da força de trabalho por mercados de trabalho (formal e informal) e empregadores e por categorias (faixa etária, anos de estudo, região, raça, gênero, e setor de atividade econômica), para população brasileira em 1995, com idade entre 25 e 65 anos, residentes no setor urbano

7. Rendimentos médios (por hora trabalhada) setoriais por grupos de sexo no Brasil em 1995 (para população ocupada com idade entre 25 e 65 anos residentes no setor urbano), valores expressos em Reais.

8 Rendimentos médios (por hora trabalhada) regionais por grupos de sexo no 
Brasil em 1995 (para população ocupada com idade entre 25 e 65 anos residentes no setor urbano), valores expressos em Reais.

9 Rendimentos médios (por hora trabalhada) por níveis de escolaridade e sexo no Brasil em 1995 (para população ocupada com idade entre 25 e 65 anos residentes no setor urbano), valores expressos em Reais.

10 Equações de participação da força de trabalho para homens e mulheres nos mercados de trabalho formal e informal e para empregadores. Efeitos marginais (em negrito), coeficientes e testes-t (em parênteses).............................................

11 Funções de Rendimentos para homens e mulheres nos mercados de trabalho formal e informal e para empregadores

12 Retornos à experiência, em porcentagem, ao ano

13 Retornos à escolaridade, em porcentagem, ao ano.

14 Retornos à educação por níveis de escolaridade para mulheres casadas e solteiras, para empregadas no setor formal e informal e para trabalhadoras por conta própria, em porcentagem.

15 Número de anos de experiência onde os rendimentos atingem o valor máximo, para homens e mulheres no mercado de trabalho formal e informal 100

16 Média dos logaritmos dos rendimentos-hora observados para homens e mulheres e estimados para mulheres, em reais de 1995

17 Média dos logaritmos dos rendimentos-hora observados nos mercados formal e informal e estimados para o mercado informal, em reais de 1995

18 Rendimento médio por hora de trabalho, em reais de 1995, nos mercados de trabalho formal e informal, para empregadores e total 
19 Média dos logaritmos dos rendimentos-hora observados para homens e mulheres (branco, pardo e preto) e estimados para homens e mulheres (pardo e

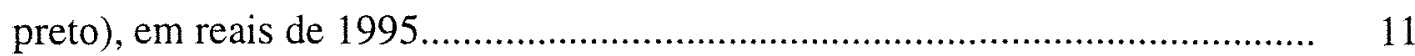

20 Decomposição dos diferenciais de rendimentos devido as características produtivas e discriminação, em porcentagem. 


\title{
MERCADOS DE TRABALHO FORMAL E INFORMAL: UMA ANÁLISE DA DISCRIMINAÇÃO E DA SEGMENTAÇÃO
}

\author{
Autora: NANCY DE DEUS VIEIRA SILVA \\ Orientadora: Profa. Dra. ANA LÚCIA KASSOUF
}

\section{RESUMO}

Foram analisados neste trabalho os determinantes da participação e rendimentos nos mercados de trabalho formal e informal e para empregadores, para homens e mulheres de 25 a 65 anos, vivendo no setor urbano no Brasil. Retornos à escolaridade e experiência, segmentação do mercado de trabalho e discriminação salarial por gênero e por cor foram analisados, tendo como base os coeficientes estimados das funções de rendimentos.

Equações de participação foram estimadas por máxima verossimilhança usando o modelo lógite multinomial, onde a variável dependente toma o valor 0 se a pessoa não trabalha, 1 se o indivíduo trabalha no mercado formal, 2 se o indivíduo trabalha no mercado informal e 3 se o indivíduo é empregador. Baseado nos coeficientes estimados no modelo descrito acima, a variável lambda (inverso da razão de Mill) foi calculada e utilizada como variável exógena nas equações de rendimentos para obter estimativas dos parâmetros consistentes sem viés de seletividade amostral, que pode ocorrer quando somente indivíduos que possuem rendimentos entram nos cálculos dessas equações.

Na realização desse estudo foram utilizados dados desagregados da PNAD de 1995, empreendida pelo IBGE. Os dados que compõem esta pesquisa são obtidos de uma amostra de, aproximadamente, 300.000 indivíduos, onde se têm detalhes da vida sócio-econômica de cada indivíduo.

Os resultados das equações de participação mostraram que a presença de filhos pequenos na família influenciam positivamente na participação do pai no mercado de 
trabalho, mas negativamente na participação da mãe. Filhos e filhas maiores de 12 anos afetam negativamente a participação dos pais no mercado de trabalho, agindo como substitutos da força de trabalho dos pais. O chefe da família tem maior participação na força de trabalho que o cônjuge. $O$ fato do homem ser casado afeta positivamente a sua participação no mercado de trabalho, enquanto que para as mulheres o efeito observado foi o contrário. A escolaridade teve um efeito positivo e bastante forte sobre a participação no mercado de trabalho e o nível de riqueza dos indivíduos efeito negativo. As oportunidades de emprego no mercado de trabalho formal foram maiores nas regiões mais desenvolvidas do país, enquanto as oportunidades de emprego no mercado de trabalho informal foram maiores nas regiões menos desenvolvidas.

Os resultados das equações de rendimento mostraram que a variável LAMBDA apresentou coeficientes altamente significativos, indicando que sua inclusão no modelo era necessária para evitar problemas de tendenciosidade nas estimativas dos parâmetros. A escolaridade dos trabalhadores teve um efeito positivo bastante significativo nos rendimentos, principalmente no mercado de trabalho formal. Constatou-se que os negros recebem salários menores que os brancos e pardos, indicando discriminação racial. Os trabalhadores da Região Nordeste e empregados no setor primário recebem salários menores que os demais. Observou-se ainda que a remuneração dos trabalhadores formais é maior no setor secundário que no setor terciário enquanto que a remuneração dos trabalhadores informais é ligeiramente superior no setor terciário. Ademais, os trabalhadores sindicalizados são melhores remunerados.

Com base nas equações de rendimento estimadas calculou-se os retornos à experiência e à escolaridade. Verificou-se que os retornos à experiência para os homens foram maiores no mercado de trabalho informal, enquanto para as mulheres os retornos à experiência foram maiores no mercado de trabalho formal. Os retornos à escolaridade obtidos no mercado de trabalho formal são aproximadamente 3 e 2 vezes maiores que os retornos obtidos no mercado de trabalho informal, para homem e mulher respectivamente. 
Também constatou-se que os retornos à escolaridade são maiores para as mulheres do que para os homens nos dois mercados de trabalho.

Verificou-se que a discriminação salarial por gênero ocorre em grandes proporções nos 2 mercados de trabalho, sendo maior a discriminação no mercado de trabalho formal. Concluiu-se ainda que não existe segmentação no mercado de trabalho para as mulheres, entretanto, para os homens o grau de segmentação é expressivo. Este estudo constatou a existência de discriminação racial nos mercados de trabalho formal e informal. Ademais, a menor taxa de discriminação observada foi para a mulher preta no mercado formal, enquanto que a maior foi para os homens pretos no mercado de trabalho informal.

Com base nos resultados obtidos, recomenda-se maiores investimentos em escolaridade que visem diminuir os diferenciais de salários entre os mercados de trabalho formal e informal e entre os grupos étnicos. Recomenda-se ainda políticas que visem amenizar a discriminação salarial contra as mulheres, tais como, incentivos fiscais às empresas para a contratação de mulheres. Por outro lado os planejadores econômicos devem repensar legislação trabalhista, que aumenta o custo de contratação da força de trabalho feminina, e verificar até onde tal lei está beneficiando a mulher e onde começa a prejudicá-la. 


\title{
FORMAL AND INFORMAL LABOR MARKET: A ANALYSIS OF DISCRIMINATION AND SEGMENTATION
}

\author{
Author: NANCY DE DEUS VIEIRA SILVA \\ Adviser: Profa. Dra. ANA LÚCIA KASSOUF
}

\section{SUMMARY}

This thesis analyzes the determinants of participation and earnings in the formal and informal labor markets, as well as for employer workers, for men and women from 25 to 65 years old, living in the urban sector of Brazil. Returns to education and experience, labor market segmentation, wage discrimination by gender and wage race discrimintion were also analyzed, based on the earnings equations coefficients.

Participation equations were estimated by maximum likelihood using the multinomial logit model. The dependent variable takes value 0 if the person does not work, 1 if the individual is employed in the formal sector, 2 if the individual is employed in the informal sector and 3 if he/she is employer. Based on the estimated coefficients, the variable lambda (inverse of Mill's ratio) was calculated and used as exogenous variable in the earnings equation to avoid the problem of sample selectivity bias that may occur when only individuals that have earnings enter into the analysis.

This study used individual data from a household survey (PNAD) undertaken by IBGE in 1995. There are approximately 300.000 individuals with detail information on labor.

The results from the participation equations showed that the presence of young kids affected the fathers participation positively but the mothers negatively. Teenagers had negative impact on the parents participation, acting as their substitutes in the labor force. Also, the head of the household had larger participation than the wives. Men who is married participated more in the labor market, while married women participated less. Education had an strong and positive effect on participation and wealth a negative one. 
Labor opportunities in the formal market were higher in more developed regions, while labor opportunities in the informal market were higher in less developed regions.

The results from the earnings equations showed that the coefficient of the variable lambda were highly significant, showing that the inclusion was necessary to avoid bias. Moreover, education had a highly positive and significant effect, mainly in the formal market. It was also observed that blacks receive lower wages than whites, indicating wage race discrimination. Workers living in the Northeastern region and employed in the primary sector receive less earnings than others. Workers in the formal market receive higher earnings if they are in the secondary sector, while those in the informal market receive more if they are employed in the tertiary sector. Moreover, workers that are affiliate to labor union receive higher wages.

Based on the coefficients estimated in the earnings equations it was calculated the returns to education and experience. Returns to experience, for men, are larger in the informal market, while, for women, they are higher in the formal market. Returns to education in the formal market are 3 and 2 times larger than the ones obtained in the informal market for men and women, respectively. Also, returns to education are higher for women than for men in both markets.

It was verified a large wage gender discrimination in both labor markets, being higher in the formal than informal. Moreover, labor market segmentation was not observed. This study verified the existence of wage race discrimination in the formal and informal labor markets. Moreover, the lowest discrimination rate was observed for black women the informal sector and the highest for black men in the formal sector.

Based on the results, it is possible to recommend more investment in education to decrease the wage differential between the formal and informal markets. Moreover, it is recommended government policies to reduce wage discrimination against women, such as tax benefits to enterprises that contract women. On the other hand, economic planners 
must think over work legislation which increases the costs of women labor contracts (maternal leave), verifying if the law is benefiting or actually harming them. 


\section{INTRODUÇÃO}

A hipótese central que norteia este trabalho é a de que o mercado de trabalho brasileiro está segmentado em mercado de trabalho formal, mercado de trabalho informal e empregadores.

Os termos setor formal e setor informal começaram a ser utilizados nos primórdios da década de 70 e até os dias atuais não se tem, dentro da literatura especializada, um conceito acabado, ou seja, não existe ainda um consenso entre os estudiosos do assunto sobre uma definição de setor informal.

O termo setor informal é utilizado para explicar dois fenômenos teoricamente distintos. O primeiro, discutido nos meios acadêmicos a partir de meados dos anos 70, define o setor informal como sendo o complexo das atividades econômicas em que não há uma separação nítida entre capital e trabalho. Neste primeiro enfoque, a ilegalidade dos produtores informais perante o Estado, em geral, existe, mas não é fundamental na definição de setor informal. A segunda interpretação foi proposta no fim dos anos 70 nos países industrializados para caracterizar atividades econômicas que não cumprem as regulamentações institucionais, sejam tributárias, trabalhistas, financeiras ou de outro tipo. Este conjunto de atividades - que se fixou na literatura especializada com as denominações de economia subterrânea, invisível ou submersa - não é captado pelas estatísticas oficiais de emprego, de produção e de comercialização, o que leva, portanto, a se subestimarem estes agregados. Nesta segunda abordagem, a clandestinidade perante o Estado é a principal característica do setor informal e o primeiro corte operacional para analisar aspectos relativos às atividades econômicas. 
Uma característica marcante do mercado de trabalho brasileiro é o alto grau de informalização da força de trabalho ocupada. A grande maioria de pesquisadores brasileiros que realiza estudos sobre o mercado de trabalho, utiliza o critério "empregados com ou sem carteira de trabalho assinada" para dimensionar o mercado de trabalho informal. Para captar o grau de informalização do mercado de trabalho brasileiro geralmente são utilizadas informações sobre a "posição na ocupação da PEA ocupada" contidas na PNAD (Pesquisa Nacional por Amostra de Domícilios). A categoria denominada "posição na ocupação da PEA ocupada" apresenta a seguinte subdivisão: empregados com carteira de trabalho, empregados sem carteira de trabalho, trabalhadores por conta própria, trabalhadores sem remuneração e empregadores.

Pero (1994) constatou a existência de, aproximadamente, $55 \%$ da força de trabalho ocupada com relações formais de trabalho (posse de carteira de trabalho), em 1988. Urani (1996), denominando trabalhadores formais aqueles que possuem carteira de trabalho assinada e trabalhadores informais trabalhadores sem carteira de trabalho assinada mais os trabalhadores por conta própria, observou para 1995 que apenas 48,26\% dos trabalhadores ocupados tinham empregos formais. Fernandes (1996), verificou que somente $42,3 \%$ do total da força de trabalho ocupada em 1990 era formada por empregados com contrato formal de trabalho ${ }^{1}$. Kassouf (1997), usando como delimitador de trabalhadores formais e informais a contribuição para instituição de previdência social, verificou que apenas $47,8 \%$ do total dos trabalhadores ocupados, com idade entre 18 e 65 anos, tinham empregos no setor formal.

Vários estudos empíricos realizados no Brasil, a respeito do mercado de trabalho informal tem evidenciado uma alta correlação entre a crise econômica e o aumento das relações informais de trabalho. Segundo vários pesquisadores, entre outros ver Pero (1994) e Urani (1995), os empregos no mercado de

\footnotetext{
${ }^{1}$ Empregados com contrato formal de trabalho são aqueles que possuem carteira de trabalho assinada mais os funcionários públicos.
} 
trabalho informal representam uma vigorosa fonte geradora de postos de trabalho durante períodos em que a economia opera abaixo de sua capacidade normal.

$\mathrm{Na}$ literatura brasileira frequientemente encontram-se os seguintes resultados: (1) a condição de ser trabalhador informal é mais freqüente entre os trabalhadores menos qualificados, ou seja, trabalhadores informais possuem os mais baixos níveis de escolaridade, entretanto, possuem maior experiência no mercado de trabalho que os trabalhadores formais; (2) os trabalhadores informais concentram-se mais nos extremos da distribuição etária; (3) as mulheres encontram mais oportunidades de emprego no setor informal, enquanto os homens concentram-se mais no mercado de trabalho formal; (4) os salários são mais baixos para os trabalhadores informais, tanto para os homens quanto para as mulheres, mesmo quando controlados por uma série de características individuais (gênero, experiência, escolaridade, etc.) e região de residência; (5) trabalhadores informais estão mais concentrados nas regiões menos desenvolvidas; assim, o grau de formalização da força de trabalho ocupada é maior nas regiões Sul e Sudeste, e menor nas regiões Norte, Nordeste e Centro-Oeste, dentre outros [ver Marcouiller et al. (1997), Fernandes (1996), Pero (1994), Tiefenthaler (1994) e Cacciamali (1982)].

A literatura internacional vem abrangendo o tema da segmentação no mercado de trabalho bem como da discriminação salarial, por gênero e por cor; possuindo uma vasta literatura acerca do tema; ver entre outros Marcouiller et all. (1997), Hill (1989), Brown, Moon e Zoloth (1980); Corcoran e Duncan (1979), Moser (1978). Entretanto no Brasil a dičussão acerca do tema ainda é incipiente, possuindo reduzido número de trabalhos sobre o tema; dentre outros ver Barros et all. (1997), Barros e Mendonça (1996), Fernandes (1996a), Fernandes (1996b) Tiefenthaler (1994), Pero (1994), Cacciamali e Fernandes (1993), Barros et all. (1992), Lovel (1992), Cacciamali (1980, 1991), Valle Silva (1980 e 1993). O presente trabalho tem como objetivo enriquecer a literatura brasileira acerca do tema, utilizando-se de dados recentes (1995) e estratificando-se os trabalhadores em formais, informais e empregadores, de 
modo a possibilitar uma análise da segmentação do mercado de trabalho brasileiro, bem como da discriminação por gênero e por cor nos distintos mercados de trabalho.

\subsection{Importância do problema e justificativa}

O setor informal brasileiro, segundo dados do IBGE, absorve uma parcela muito significativa da mão-de-obra brasileira, existindo uma clara tendência de ampliação da participação de trabalhadores neste setor. Em 1991, os trabalhadores por conta própria perfaziam um total de $19,95 \%$ da força de trabalho no Brasil Metropolitano; em 1995, somavam 21,86\% dos trabalhadores brasileiros (região metropolitana). Os trabalhadores sem carteira de trabalho assinada participavam com $22,51 \%$ e $25,70 \%$ da força de trabalho metropolitana brasileira, para os anos de 1991 e 1995, respectivamente. Observa-se então que, em apenas 4 anos, houve um acréscimo de quase dois pontos percentuais na participação dos trabalhadores por conta própria e mais de 3 pontos percentuais na participação dos trabalhadores sem carteira de trabalho assinada na força de trabalho brasileira. Assim, a importância deste setor para a economia não pode ser ignorada. É de crucial importância entender melhor a dinâmica do mercado de trabalho informal, para que políticas de emprego e renda sejam eficientes em seus objetivos. $O$ entendimento dos determinantes da participação e rendimentos no mercado de trabalho tanto quanto as divergências entre homem e mulher e setores formal e informal é essencial para orientar decisões políticas para diminuir a discriminação e desigualdades de renda no Brasil. Considerando as controvérsias que giram em torno da definição de setor informal e a escassez de trabalhos empíricos e com rigor teórico para o Brasil, procurar-se-á dar uma contribuição empírica para a melhor compreensão deste tema, diminuindo assim, a lacuna existente nesta área de pesquisa.

A concepção de políticas específicas para o setor informal assume uma importância fundamental. A necessidade de estabelecer tais políticas decorre de três razões principais, as quais também justificam a análise do setor informal 
como uma unidade dentro da economia urbana. Em primeiro lugar, uma alta porcentagem da força de trabalho urbana está ocupada neste setor. Em segundo lugar, as características das pessoas ocupadas neste setor (principalmente o baixo nível de escolaridade), determinam uma alta concentração dos grupos de população mais afetados pela pobreza extrema. E, por último, dado que a tendência observada nos últimos 15 anos foi de aumento da proporção de trabalhadores empregados no segmento informal do mercado de trabalho e dado que a força de trabalho ocupada neste segmento permanece fora do alcance da maioria das políticas de renda e, que se deve melhorar o nível de renda desse amplo grupo da população, é necessário implementar-se políticas específicas para este setor.

A existência da segmentação e da discriminação salarial por cor e por gênero no mercado de trabalho brasileiro já foi constatada na literatura especializada. Entretanto, ainda não está bem definido as causas dos diferenciais de salário existente entre os trabalhadores brasileiros, portanto uma pesquisa neste sentido visa contribuir para elucidar a questão e indicar caminhos para amenizar as desiguladades de renda no Brasil. Uma importante contribuição deste estudo está em se analisar os diferenciais de rendimentos entre homens e mulheres e entre brancos e não brancos diferenciando-se os mercados de trabalho (formal e informal) de modo a comparar os resultados obtidos entre os distintos mercados de trabalho.

\subsection{Objetivos}

O objetivo geral deste trabalho é, a partir da literatura especializada existente, delimitar o mercado de trabalho formal e informal brasileiro, de forma que possibilite mensurar-se a proporção de trabalhadores inseridos nestes segmentos do mercado de trabalho a partir dos dados da Pesquisa Nacional por Amostra de Domicílios (PNAD), para o ano de 1995. A partir das amostras de trabalhadores nos 
diversos segmentos do mercado de trabalho serão analisados os determinantes da participação e dos rendimentos em cada mercado de trabalho.

Especificamente pretende-se:

a) Verificar a proporção do trabalho informal nos três setores de produção da economia (primário, secundário e terciário) ${ }^{2}$ no Brasil, bem como nas grandes regiões, procurando determinar as causas dos comportamentos encontrados, analisando a influência do desenvolvimento das regiões sobre a participação dos trabalhadores informais dentro da mão-de-obra total.

b) Analisar os determinantes da participação e rendimentos nos mercados de trabalho formal e informal e para empregadores, separando-se homens e mulheres em grupos diferentes, de maneira a possibilitar comparações entre eles nos diversos mercados de trabalho. Com base nos coeficientes das equações de participação e rendimentos estimados serão feitas comparações entre os mercados de trabalho formal e informal e empregadores, e entre homens e mulheres para os três segmentos de trabalhadores.

c) Calcular os retornos à experiência e à escolaridade e comparálos entre homens e mulheres nos mercados de trabalho formal $\mathrm{e}$ informal $\mathrm{e}$ empregadores, e verificar qual o número de anos de experiência em que os trabalhadores atingem o máximo rendimento.

${ }^{2}$ Uma das classificações mais correntes das atividades produtivas foi originariamente proposta por Colin Clark. Nessa formulação existem três setores básicos na economia de um país. O setor primário reúne as atividades agropecuárias e extrativas (vegetais e minerais). O setor secundário engloba a produção de bens físicos por meio da transformação de matérias-primas, realizada pelo trabalho humano com o auxílio das máquinas e ferramentas: inclui toda a produção fabril, a construção civil e a geração de energia. O setor terciário abrange os serviços em geral: comércio, armazenagem, transportes, sistema bancário, saúde, escolaridade, telecomunicações, fornecimento de energia elétrica, serviços de água e esgoto e administração pública. A importância relativa de cada um destes setores no produto total da economia de um país é bastante variável. $O$ grau de desenvolvimento econômico de uma nação determina a importância relativa de cada setor na composição do produto total da economia. Nas economias subdesenvolvidas, predominam as atividades primárias e é precário o desenvolvimento dos setores secundário e de serviços, mais presentes nos países desenvolvidos. 
d) Verificar se as rendas percebidas no mercado de trabalho informal são menores que as rendas percebidas pelos trabalhadores que participam do segmento formal da economia. Para atingir tal objetivo serão observadas as rendas de grupos de pessoas ocupadas em segmentos distintos (formal e informal) mas que apresentem as mesmas características pessoais e produtivas.

e) Verificar a existência de desigualdade salarial devido à segmentação no mercado de trabalho (segmentos formal e informal da economia) e a desigualdade salarial vinculada à discriminação por gênero e por cor.

Para a realização deste trabalho foi adotada a visão que destaca o acesso à carteira de trabalho como linha divisória entre o mercado de trabalho formal e o mercado de trabalho informal. Os empregados com carteira de trabalho assinada e os funcionários públicos são identificados como trabalhadores formais, enquanto aqueles sem carteira de trabalho assinada e os trabalhadores por conta própria compõem a categoria de trabalhadores informais. A categoria denominada empregadores será analisada em separado devido a suas características serem bastante particulares e diferenciarem-se dos demais trabalhadores.

Visando atingir tais objetivos serão estimadas equações de rendimentos nos mercados de trabalho formal e informal e para empregadores, para homens e mulheres separadamente e também por grupos de raça. Essas equações serão corrigidas pelo procedimento de Heckman (1980) para evitar problemas de viés de seletividade amostral que pode ser observado quando somente trabalhadores que possuem rendimentos entram nos cálculos das equações de rendimentos. A simples estimação dessas equações, utilizando-se a técnica de mínimos quadrados ordinários, pode produzir estimativas dos parâmetros tendenciosas e inconsistentes. Essa correção será feita estimando-se um modelo lógite multinomial de participação nos diversos mercados de trabalho. A partir das estimativas dos parâmetros será obtida a variável "lambda", a qual será utilizada como variável exógena na equação de rendimentos. Com 
base nas equações de rendimentos estimadas também serão calculados os retornos à experiência e à escolaridade os quais serão comparados entre homens e mulheres nos mercados de trabalho formal e informal e empregadores. Baseados nas equações de rendimento também será verificada a existência de desigualdade salarial devido à segmentação no mercado de trabalho e a existência de desigualdade salarial vinculada à discriminação por gênero e por cor. Este estudo utiliza os dados individuais da Pesquisa Nacional por Amostra de Domicílios (PNAD) de 1995.

\subsection{Organização deste estudo}

Este estudo está organizado em sete capítulos. No capítulo 01 são apresentadas informações gerais sobre o tema em questão, a importância e justificativa do problema e os objetivos. No capítulo 02 apresenta-se a revisão de literatura, a qual é subdividida em duas seções. A primeira é destinada à revisão das diversas abordagens existentes sobre o setor informal; na segunda são apresentados diversos estudos passados acerca do tema, cobrindo estudos realizados sobre o Brasil e outros países. O capítulo 03 descreve a metodologia empregada na análise dos dados, "O modelo de respostas múltiplas com seletividade amostral". No capítulo 04 são discutidos os dados e apresentada a descrição estatística das variáveis empregadas neste estudo. $\mathrm{O}$ capítulo 05 apresenta a descrição e análise da amostra, a qual poderá auxiliar e dar suporte à análise dos resultados. No capítulo 06 são apresentados e discutidos os resultados obtidos nas equações de participação e equações de rendimentos nos distintos mercados de trabalho, para homens e mulheres, comparando-se os resultados. Também são feitas neste capítulo análises acerca da segmentação e discriminação salarial, por gênero e por cor, no mercado de trabalho. No capítulo 07 é feita uma síntese dos principais resultados obtidos nas equações de participação e de rendimentos. O capítulo 8 apresenta as conclusões do trabalho. 


\section{REVISÃo BIBLIOGRÁFICA}

\subsection{As controvérsias sobre o conceito de setor informal}

Aqui serão apresentadas as abordagens teóricas de maior importância na literatura econômica, as quais têm sido pontos de referência para a grande maioria dos estudos realizados. Nesse sentido, serão analisadas cinco abordagens: (1) O relatório do Quênia (Organização Internacional do Trabalho - OIT); (2) O enfoque do Programa Regional do Emprego para a América Latina e o Caribe (PREALC); (3) A abordagem subordinada e intersticial; (4) O enfoque da economia subterrânea e (5) O enfoque usualmente adotado no Brasil: "o acesso à carteira de trabalho".

As duas primeiras abordagens explicam a origem do setor informal, a partir do excedente de mão-de-obra do setor formal. As diferenças estão no contexto histórico em que foram formuladas e no maior aprofundamento conceitual no enfoque do PREALC. O setor informal foi definido originalmente em trabalho da OIT como sendo composto por atividades econômicas realizadas por pequenos proprietários e seus familiares, podendo a definição ser estendida para atividades realizadas por trabalhadores autônomos ou por conta própria. Para a América Latina, o PREALC define o setor informal de forma mais abrangente, sendo composto por empregadores, empregados e familiares que trabalham em estabelecimentos de até quatro empregados, trabalhadores por conta própria, em serviços domésticos e ocasionais. Nota-se uma diferença entre essas duas definições: a primeira permite associar diretamente o setor informal a relações de trabalho não assalariadas; a segunda agrega relações de trabalho 
diversas e mistas.

A terceira definição busca a origem do setor informal no próprio processo de acumulação capitalista como uma forma de organização da produção subordinada e intersticial. Estas três primeiras abordagens definem o setor informal como representando o conjunto das atividades econômicas em que não há uma separação nítida entre capital e trabalho. A quarta trata da segunda interpretação para o setor informal lançada no fim da década de 70 pelos países industrializados, focalizando as causas da informalidade nas falhas do sistema legal e político, ou na regulamentação da economia por parte do Estado. E a quinta abordagem adota o acesso à carteira de trabalho como linha divisória entre o mercado de trabalho formal e o mercado de trabalho informal.

\subsubsection{O Relatório do Quênia e a origem do setor informal}

Segundo Chully (1992) o termo setor informal foi introduzido, pela primeira vez, por Keith Hart, em 1971, num estudo sobre o emprego e a renda urbana de Ghana, o qual foi logo adotado no Relatório da Missão do Quênia (1972), dentro do Programa Mundial do Emprego da Organização Internacional do Trabalho $^{3}$. Este relatório apresentou uma nova categoria analítica, formal/informal, alternativa à dicotomia setores moderno/tradicional para analisar a estrutura das atividades produtivas. O relatório, em vez de dicotomizar entre área rural e área urbana, ou entre renda do trabalho e renda do capital, diferencia pobres de ricos, tanto na área rural como na área urbana. Esta corrente de interpretação acredita na coexistência dos setores formal e informal em ambas as áreas (rural e urbana), sendo que o primeiro gera, na média, rendas altas e o segundo, rendas baixas.

${ }^{3}$ O Programa Mundial do Emprego foi criado em 1969 para analisar o problema do emprego nos países subdesenvolvidos e em processo de industrialização, e assim propor uma estratégia de desenvolvimento cujo objetivo principal era o emprego. Para isso, formaram-se em 1970 missões de estudo em quatro países: Colômbia, Sri Lanka, Quênia e Irã. 
A instituição da nova categoria de análise, formal/informal, utilizada em países em desenvolvimento para analisar a estrutura de produção, de emprego e de renda, justificava-se, segundo os autores do trabalho sobre o Quênia, pois o rápido processo de industrialização tinha criado diversas atividades produtivas que, embora modernas, tinham características particulares: não eram organizadas com base no trabalho assalariado e seu nível de remuneração era bastante diferente desse setor, situando-se próximo dos níveis de remuneração das atividades tradicionais. O Relatório do Quênia utilizou as características das empresas como a base para dicotomizar a estrutura econômica entre setor formal e informal. Estes setores se definem pela enumeração de um conjunto de características básicas da organização produtiva de um deles. O outro define-se por oposição; deste modo a definição do setor informal tem um caráter residual, no sentido de identificar seu espaço econômico, por oposição, daquele ocupado pelo setor formal.

Deste modo, segundo a OIT, citado por Nunura Chully (1992), o setor formal apresenta as seguintes características: (a) defronta-se com barreiras à entrada; (b) depende de recursos externos; (c) a propriedade do empreendimento é impessoal; (d) opera em larga escala; (e) utiliza processos produtivos intensivos em capital e a tecnologia é importada; (f ) a mão-de-obra adquire qualificações requeridas por meio de escolaridade formal; e, (g) atua em mercados protegidos (via taxas alfandegárias, quotas e patentes comerciais).

As características do setor informal são, precisamente, as opostas: (a) facilidade de entrada; (b) o aporte de recursos é de origem doméstica; (c) a propriedade do empreendimento é individual ou familiar; (d) opera em pequena escala; (e) utiliza processos produtivos intensivos em trabalho e tecnologia adaptada; (f) a mãode-obra qualifica-se externamente ao sistema escolar formal; e, (g) atua em mercados não regulamentados e competitivos. 
O conceito de setor informal apresentado, por ser intuitivo e de grande utilidade prática, foi rapidamente incorporado pela literatura especializada, sem entretanto cumprir, nesta primeira fase de elaboração teórica e de aplicação empírica, a nenhum rigor ou homogeneidade, gerando desta forma muitas interpretações erradas, dúvidas e críticas.

\begin{abstract}
"A divisão da economia em dois setores é por demais simplista para refletir a realidade das estruturas de produção e de emprego de qualquer país, ainda mais quando o palco de estudos é uma sociedade em desenvolvimento. Em seguida, embora o conceito de dicotomia tivesse sido renominado - passando de tradicional/moderno para formal/informal - a maior parte das análises sobre o tema continuou a adotar uma abordagem dual estática que confrontava com os processos dinâmicos, e muitas vezes muito velozes, do produto e do emprego dos países em desenvolvimento. Muitos estudos, além do mais, continuaram a interpretar os dois setores como sendo independentes um do outro, o que nitidamente contrariava as observações do mundo real" (Cacciamali, 1991, p. 124).
\end{abstract}

O setor informal era ainda associado aos segmentos mais pobres da população ocupada, sem levar em conta as formas de inserção do trabalhador no setor produtivo - se por conta própria ou assalariado - assim como a forma de organização do estabelecimento produtivo e sua inserção no mercado de bens ou produtos e a estrutura heterogênea e diversificada do setor informal.

A maior parte das análises realizadas a partir deste quadro de racionalização concluía que com o crescimento econômico o setor informal provavelmente seria extinto. Devido às interpretações viesadas do conceito de informalidade proposto no trabalho original, as medidas de intervenção pública no setor eram propostas em níveis muito gerais, o que resultava em baixos índices de eficiência 
das medidas públicas, já que a extensa e complexa heterogeneidade do setor informal não era levada em consideração no momento da formulação de políticas para o mesmo.

As formas de mensuração, como resultado das interpretações viesadas do setor informal, divergiram muito nessa primeira fase. As divergências principais para mensurar o setor informal residem tanto na escolha da categoria de análise - ocupados ou estabelecimentos produtivos - como nas normas consideradas para extrair o setor informal a partir da análise dessas duas categorias.

\subsubsection{A interpretação do PREALC}

No início dos anos setenta a definição de setor informal foi introduzida nos países da América latina através dos estudos do Programa Regional do Emprego para a América Latina e o Caribe (PREALC), instituição de nível regional pertencente à OIT, como parte do programa mundial do emprego. Na primeira metade dos anos 70, o PREALC introduziu o conceito de setor informal à questão do desenvolvimento regional, promoveu estudos sobre o setor informal em várias economias da América Latina e prestou assistência à alguns governos latino-americanos em assuntos relativos a desenvolvimento e emprego.

Os estudos do PREALC acompanham o marco conceitual do Relatório do Quênia (1972), caracterizando-se pela ênfase dada a dois elementos importantes. Primeiro, explicar, no contexto do desenvolvimento latino-americano, a origem e a inter-relação do setor informal com o setor formal da economia e, segundo, tentar definir políticas direcionadas ao setor informal a fim de melhorar a produtividade e os níveis renda dos trabalhadores deste setor. 
Victor Tokman ${ }^{4}$ (um dos principais autores do PREALC), citado por Cacciamali (1982), entende que o setor informal é constituído pelo grupo de empresas com baixo nível de produtividade, os trabalhadores independentes (exceção feita aos profissionais liberais) e empresas muito pequenas ou não organizadas ${ }^{5}$, que utilizam processos tecnológicos simples e estão inseridas em mercados competitivos. $O$ número de trabalhadores ocupados neste mercado depende da magnitude da força de trabalho que não encontra oportunidade de trabalho dentro do setor formal da economia e, das oportunidades que têm esses indivíduos de produzir ou vender alguma coisa que lhes proporcione algum rendimento. A origem do setor informal é considerada nestes estudos como sendo resultado do padrão de desenvolvimento capitalista em vigor na região substituição de importações - que gera poucos empregos que, juntamente com padrão de crescimento demográfico e migração, gera grande excedente de mão-de-obra a qual se auto-emprega para sobreviver.

Os estudos do PREALC afirmam, ainda, que os setores formal e informal participam de um mesmo mercado, onde o setor informal caracteriza-se por ser composto de um conjunto de atividades pouco capitalizadas, estruturadas em unidades produtivas muito pequenas, operando com tecnologias simples. Nas empresas que compõem este setor, não predomina a divisão entre proprietários do capital e do trabalho, cuja característica é do setor formal, e consequentemente o salário não é a forma mais usual de remunerar o trabalho, apesar de que a produção está voltada principalmente para o mercado. Os produtores deste setor têm acesso àqueles estratos de mercado competitivos onde a atomização da oferta é tal que não possibilita a nenhum produtor determinar preços, não permitindo desta forma que estes obtenham ganhos extraordinários.

${ }^{4}$ Tokman, V. E. An exploration into the nature of informal-formal sector relationships in World Development, vol. 6, no 9/10, outubro de 1978, p. 1065-1076.

5 A denominação aqui utilizada refere-se a atividades ou empresas "não organizadas em termos capitalistas", onde não se distingue a propriedade do trabalho e do capital e onde o salário não é a forma usual de remuneração do trabalho. 
Um aspecto importante do enfoque do PREALC "refere-se à identificação do setor informal com o conjunto de empresas e pessoas de baixa produtividade e baixa renda como consequiência da falta de proteção da política econômica e difícil acesso aos mercados onde participa o setor formal... Os trabalhadores são pobres porque estão inseridos no setor informal, em atividades de fácil entrada e segmentos competitivos do mercado em que não existe lucro oligopólico. Todos os trabalhadores informais são homogeneizados como os mais pobres da cidade. Segundo o PREALC, constituem o último anel da cadeia determinada pela heterogeneidade estrutural. Reconhece-se, apenas diferenciação ao interior da estrutura produtiva e ocupacional do setor formal e, por sua vez, determinante da diferenciação salarial existente neste setor. Nesta estrutura salarial, os trabalhadores formais do último degrau têm renda média superior ao trabalhador informal" ( Nunura Chully, 1992, p. 204 ).

A hipótese de homogeneidade foi um suposto muito forte nos estudos iniciais do PREALC. Os estudos dos anos 80 reconhecem claramente a existência de diferenciação dentro do setor informal.

"Contrariamente à imagem prevalecente de quinze anos atrás, no sentido de que o setor informal era de natureza homogênea, na atualidade é evidente que existem segmentos distintos dentro deste setor... Apesar da heterogeneidade do setor informal, as rendas deste setor tendem a se determinarem dentro de uma escala limitada, isto é, a renda dos trabalhadores neste setor não varia de forma significativa. Isso é conseqüência, por um lado, da concorrência direta do mercado de trabalho, nas atividades realizadas pelo indivíduo, ..., e, por outro, da facilidade de entrada aos mercados competitivos (característica 
intrínseca a este setor), o que determina que não se podem obter rendas extraordinárias no mercado de produtos" ${ }^{\text {. }}$.

A participação do setor informal na totalidade dos ramos da produção e nos mercados, para essa corrente de interpretação, não pode aumentar continuamente. À medida que as atividades econômicas se diversificam, a tendência é reduzir-se o espaço da economia ocupado pelo setor informal. Se uma atividade econômica desempenhada pelo setor informal atingir tamanho de mercado que possibilite sua exploração sob os moldes da produção capitalista e, simultaneamente, existir tecnologia que possa ser empregada para desempenhar esta atividade, de modo a possibilitar ganhos de escala, o setor informal perde este mercado para as firmas capitalistas. A expansão do setor informal pode se dar em termos quantitativos em função do excedente de mão-de-obra, a qual não decresceria, seja em função da incapacidade do setor formal absorver todo ou maior parte do excedente de mão-de-obra ou da evolução do mercado de trabalho na área rural e dos altos índices de crescimento demográfico, implicando níveis de renda decrescentes para trabalhadores do setor informal.

Tokman, citado por Nunura Chully (1992), afirma que estudos recentes do PREALC incorporam o fator institucional - a normatividade legal e institucional - para explicar o não cumprimento das normas legais por parte do setor informal. Os pesquisadores do PREALC acreditam que o não cumprimento das leis é resultado da dinâmica mas não a causa do funcionamento do setor. Reconhecem que grande parte dos informais opera fora dos limites da legalidade, em razão da incapacidade real para cumprir as normas vigentes, embora exista vontade de cumpri-las. A legalização implica gastos de registro, pagamento de tributos, maiores custos laborais, etc., que podem afetar o pequeno excedente gerado pelo produtor informal e até eliminálo do mercado. Mas, a não legalidade implica, em contrapartida, desproteção ao produtor

\footnotetext{
${ }^{6}$ TOKMAN,V. E. El Sector Informal: quinze años después. em Trimestre Econômico, Fondo de Cultura, México ,1987, citação retirada de Nunura Chully, 1992, p.205.
} 
e aos trabalhadores informais nas áreas de crédito, seguridade social, salários mínimos, etc..

\subsubsection{A abordagem subordinada e intersticial}

A partir da segunda metade dos anos 70 o setor informal passou a ser abordado com base nas relações do trabalhador com os meios de produção (Gerry, 1978; Moser, 1978; Souza, 1980 e Cacciamali, 1982,1989a, 1989b, 1989c). A partir daí o setor informal " é definido como o conjunto das atividades econômicas em que o produtor direto, de posse dos instrumentos de trabalho e com a ajuda de mão-de-obra familiar ou de alguns ajudantes, produz bens ou serviços" (Cacciamali, 1991, p. 125).

"O novo enfoque rompe a abordagem dual estática substituindo-a por um enfoque dinâmico, subordinado e intersticial. Entende-se que os movimentos e a dinâmica das atividades tipicamente capitalistas, ao mesmo tempo que criam uma configuração para outras atividades formais também propiciam espaços econômicos que podem ser explorados por pequenos produtores e por trabalhadores por conta própria. O espaço informal, portanto, transforma-se, ao longo do tempo, subordinado aos movimentos da produção tipicamente capitalista e aos decorrentes perfis de demanda e de distribuição de renda. Assim, ao longo do tempo, as atividades informais existentes sobrevivem, morrem ou se transformam, enquanto, incessantemente, outras possibilidades para produtores informais estão sendo gestadas. Logo, o espaço econômico informal, que é intersticial às atividades econômicas dominantes, é ocupado de forma permanente e constitui parte integrante de um mercado de trabalho em equilíbrio, embora o tipo de produtores e a oferta de bens e de serviços modifiquem-se ao longo do tempo" (Cacciamali, 1991, p. 126). 
A hipótese central derivada do que foi dito anteriormente consiste em que a acumulação capitalista cria, destrói e recria o espaço econômico ocupado pelo setor informal. O setor informal não tem capacidade de crescimento autônomo, sua expansão é possível, no entanto sua dinâmica é totalmente dependente dos movimentos do capital, isto é, a produção informal sofre contínuos deslocamentos pela ação da produção tipicamente capitalista. É neste sentido que se explica a existência da relação subordinada e intersticial do setor informal com o setor formal.

A origem do setor informal "está na própria acumulação capitalista e não simplesmente no excedente de mão-de-obra do setor formal, pois seu espaço econômico é delimitado e permanentemente reproduzido pela expansão e reprodução do capital" (Nunura Chully, 1992, p. 215).

Segundo esta abordagem, o setor informal é definido como o setor de pequena produção não tipicamente capitalista, isto é, unidades produtivas não organizadas com base no trabalho assalariado, onde não existe separação nítida entre a propriedade dos meios de produção e do trabalho. Se o trabalho assalariado existe, não é utilizado de forma regular ou permanente, e não é fundamental para a continuidade das atividades produtivas informais. O objetivo fundamental dos produtores informais não é a procura de uma determinada taxa de lucro competitiva que permita gerar acumulação de capital. O objetivo principal destes produtores é maximizar o fluxo de renda total para atender, prioritariamente, os gastos de consumo individual e familiar e, logo, a manutenção da unidade produtiva. Esta forma de organizar a produção, de modo geral, não permite acumulação de capital, nem saltos tecnológicos e quando estes últimos ocorrem são uma resposta aos movimentos de redefinição do espaço e das formas de exploração do setor formal. Assim, Paulo R. Souza ${ }^{7}$ (1980), citado por Nunura Chully (1992), apresenta uma tipologia composta de cinco unidades produtivas: (a) empresas

\footnotetext{
${ }^{7}$ Souza, P. R. A determinação da taxa de salários em economias atrasadas. Campinas, Tese (doutorado) IFCH/UNICAMP, 1980
} 
quase capitalistas ${ }^{8}$; (b) empresas familiares ou trabalhadores autônomos (excluindo os profissionais liberais independentes) ${ }^{9}$; (c) trabalhadores por conta própria subordinados; (d) pequenos vendedores de serviços e (e) serviço doméstico -são incorporados aqui pois, embora assalariados, os trabalhadores domésticos vendem seus serviços a unidades de consumo (famílias), uma ou mais, e não a firmas, Estado ou demais organizações.

Esta abordagem conceitua a economia em termos de um continuum de formas de organização da produção ao invés de uma divisão em apenas dois setores, o que foi amplamente desenvolvido por Cacciamali (1982). A economia é vista como um continuum de trabalhadores dentro do processo produtivo. Além do trabalho assalariado inserido na firma tipicamente capitalista, há um espectro de distintas ocupações conformadas pelo assalariamento sem contrato legal de trabalho, o assalariamento ocasional ou temporário, o assalariamento sazonal, o assalariamento disfarçado (trabalhadores autônomos subordinados a determinada e única firma), o trabalhador por conta própria, o produtor e proprietário de pequenos estabelecimentos, o trabalhador não remunerado, o serviço doméstico, entre outros.

"O perfil ocupacional passa a ser distinguido, dessa maneira, por uma forte heterogeneidade e, no que se refere ao espaço econômico do setor informal, deve ser destacado que é um locus de trabalhadores altamente diferenciados quanto às ocupações, às condições de trabalho e aos níveis de renda. Ali, inserem-se trabalhadores que por opção,

\footnotetext{
${ }^{8}$ A empresa quase capitalista refere-se aos pequenos produtores que têm apoio de trabalho remunerado de forma regular e estão em atividades de maior complexidade tecnológica dentro da pequena produção. As categorias, de (a) a (e), caracterizam-se por sua facilidade de entrada e nas quais a renda média é uma variável de ajuste.

${ }^{9}$ É considerado autônomo, quem presta serviços de natureza urbana ou rural, em caráter eventual, a uma ou mais empresas, sem relação de emprego; e a pessoa física que exerce, por conta própria, atividade econômica de natureza urbana, com fins lucrativos ou não (letras "a" e "b" do inciso IV do art. da Lei n" $8.212 / 91$ ). Profissional liberal é aquele que exerce com independência ou autonomia profissão ligada à aplicação de conhecimentos técnicos e científicos, cuja natureza intelectual é comprovada, geralmente, por meio de título de habilitação expedido em forma legal. Consideram-se liberais as profissões de advogados, médicos, dentistas, engenheiros, arquitetos, contadores, economistas, jornalistas etc., as quais constituem categorias integrantes da Confederação Nacional das Profissões Liberais.
} 
pelas habilidades e pela qualidade dos serviços prestados auferem, relativamente altos níveis de renda quando comparados com a média dos assalariados, como também existem indivíduos que, sem nenhuma qualificação, não podem ser absorvidos por firmas organizadas e que findam por receber remunerações insuficientes perante o padrão médio mínimo de vida social" (Cacciamali, 1991, p. 127).

As características que definem o setor informal podem ser sintetizadas nos seguintes itens:

“(a) o produtor direto é o possuidor dos instrumentos de trabalho e/ou de estoque de bens para realização de seu trabalho e se insere na produção sob a forma simultânea de patrão e empregado; (b) ele emprega a si mesmo e pode lançar mão de trabalho familiar ou de ajudantes como extensão do seu próprio trabalho, obrigatoriamente participa diretamente da produção e conjuga essa atividade com aquela de gestão; (c) o produtor direto vende seus serviços ou mercadorias e recebe um montante de dinheiro que é utilizado principalmente, para consumo individual e familiar e para manutenção da atividade econômica, e, mesmo que o indivíduo aplique seu dinheiro com o sentido de acumular, a forma como se organiza a produção, com apoio no próprio trabalho, em geral, não lhe permite tal acumulação; (d) a atividade é dirigida pelo fluxo de renda que a mesma fornece ao trabalhador e não por uma taxa de retorno competitiva, é desta renda que se retiram os salários dos ajudantes ou empregados que possam existir; (e) nesta forma de produzir, não existe vínculo impessoal e meramente de mercado entre os que trabalham - entre estes encontra-se com frequiência a mão-de-obra familiar; (f) o trabalho pode ser fragmentado em tarefas, mas isso não impede ao trabalhador apreender todo o processo que origina o produto ou serviço final, processo este 
muitas vezes descontínuo ou intermitente, seja pelas características da atividade, pelo mercado ou em função do próprio produtor" (Cacciamali, 1982, p. 29).

\title{
2.1.4 O enfoque da economia subterrânea
}

No final da década de 70 , nos países industrializados, em virtude da reversão dos níveis de atividade econômica, do aumento do desemprego e da aceleração dos níveis de inflação, alguns autores passaram a adotar diversos termos indistintamente, entre os quais economia informal, para caracterizar as atividades econômicas que não cumprem as regulamentações institucionais, sejam fiscais, trabalhistas, sanitárias, financeiras, cambiárias ou de qualquer outro tipo relacionado com a produção e circulação dos bens e serviços. Este conjunto de atividades - que se fixou na literatura especializada com as denominações de economia subterrânea, invisível ou submersa - não é captado pelas estatísticas oficiais de emprego, de produção e de comercialização, o que leva, portanto, a se subestimarem estes agregados.

\begin{abstract}
"A ilegalidade, nessa interpretação do setor informal, é a principal delimitação e o primeiro corte operacional para analisar e desagregar outros aspectos relativos às atividades econômicas. Enquanto no conceito de setor informal apresentado anteriormente, a ilegalidade poderia constituir-se numa característica conexa à atividade econômica, mas não era fundamental para distinguir uma atividade formal de uma informal; pois, a forma de organização da produção de uma determinada atividade econômica era o corte teórico-operacional básico para essa diferenciação" (Cacciamali, 1991, p. 131).
\end{abstract}

O pressuposto principal, na conceituação de economia subterrânea, é de que as empresas formais e informais funcionam de acordo com a 
mesma racionalidade econômica - a acumulação, a única distinção entre elas é a ilegalidade, ou não, perante às instituições.

O surgimento das atividades submersas, segundo os analistas do tema, deve-se à forma interveniente do Estado na economia, o incentivo para a expansão dessa economia cresce com a excessiva regulação pública, o crescimento do setor público e a elevação das taxas tributárias. Vito Tanzi ${ }^{10}$, citado por Nunura Chully (1992), classifica os fatores determinantes da economia subterrânea em quatro categorias: impostos, regulamentações, proibições e corrupção burocrática. A economia subterrânea pode ser conseqüência de um ou mais desses tipos de fatores.

\subsubsection{A interpretação de mercado de trabalho informal usualmente adotada por pesquisadores brasileiros}

A grande maioria de pesquisadores brasileiros que realiza estudos sobre o mercado de trabalho, utiliza o critério "empregados com ou sem carteira de trabalho assinada" para dimensionar o mercado de trabalho informal. Adotam o acesso à carteira de trabalho como linha divisória entre o mercado de trabalho formal e o mercado de trabalho informal.

Os empregados com carteira de trabalho e os funcionários públicos são identificados como trabalhadores formais, enquanto aqueles sem carteira de trabalho assinada e os trabalhadores por conta própria compõem a categoria de trabalhadores informais.

“Os empregados com contrato informal de trabalho se concentram nas pequenas unidades produtivas e nas mais tradicionais. Dados do IBGE, para 1990 , mostram que $60,3 \%$ dos empregados sem contrato formal

\footnotetext{
${ }^{10}$ Tanzi, V. The underground economy in The United States and abroad. Lexington Heath Werks, 1982.
} 
estavam em empresas de até 5 empregados, enquanto que para os empregados com contrato formal esta proporção era de apenas $10,8 \%$. Por outro lado, Cacciamalli (1993) mostra que, para a região metropolitana de São Paulo, $16 \%$ dos empregados do setor privado não possuíam contrato formal de trabalho, sendo que esta proporção se eleva para $57 \%$ quando apenas as empresas com até 5 empregados são consideradas" (Fernandes, 1996).

Segundo pesquisadores que adotam esta interpretação para analisar questões relativas ao mercado de trabalho, empregos que não oferecem contratos formais de trabalho são relativamente mais fáceis de encontrar e oferecem salários significativamente inferiores aos salários de empregos com contrato formal de trabalho, mesmo quando controlados por uma série de características individuais (principalmente escolaridade, idade, gênero), região de residência e ocupação.

Nesta linha de pesquisa, a principal explicação para a alta proporção de empregados com contrato informal de trabalho e de trabalhadores por conta própria deve-se aos custos decorrentes dos excessivos controles do estado.

"Estabelecer contratos formais de trabalho envolve custos (impostos, encargos sociais, legislação de salário mínimo, multa por demitir trabalhadores, etc.) e, portanto, também envolve custos para as empresas (de forma simplificada, o valor da multa vezes a probabilidade da empresa ser autuada) e, pelo menos parte dos custos impostos pela legislação podem ser vistos como salários indiretos. Assim, a extensão de empregados sem contrato formal de trabalho dependeria da conjunção dessas variáveis.

Por este ponto de vista, estaria na ação do Estado a principal explicação para o problema, seja porque ele impõe elevados custos de controles e de encargos, seja por sua ineficiência na 
fiscalização ou por manter péssimos serviços que são assegurados aos empregados com contrato formal, como por exemplo, os baixos valores de benefícios do sistema de seguridade social. Já a tendência declinante da participação de empregados com contrato formal de trabalho se daria em virtude das freqüentes elevações dos custos impostos pela regulamentação do Estado.

Cabe salientar que os custos de se contratar à margem da legislação devem variar de acordo com o porte da empresa. Empresas maiores são mais visíveis aos olhos da fiscalização. Portanto, esse raciocínio ajudaria a explicar porque o contrato informal é mais comum nas pequenas empresas" (Fernandes, 1996).

Vale destacar que este enfoque é diferente do enfoque da economia subterrânea. A economia subterrânea é caracterizada por atividades econômicas que não cumprem as regulamentações institucionais, sejam fiscais, trabalhistas, sanitárias, financeiras, cambiárias ou de qualquer outro tipo relacionado com a produção e circulação dos bens e serviços. Enquanto o último enfoque apresentado caracteriza-se somente pelas relações de trabalho entre empregador e trabalhador. Tendo como base de dados a PNAD, para captar a invisibilidade da força de trabalho, com base no enfoque da economia subterrânea, os pesquisadores utilizam informações sobre a "contribuição para a Previdência Social por parte da PEA ocupada"; enquanto que para captar o grau de formalização do mercado de trabalho são usadas as informações sobre a categoria denominada "posição na ocupação da PEA ocupada". Quanto a esta última categoria a PNAD apresenta a seguinte subdivisão: empregados com carteira de trabalho, empregados sem carteira de trabalho, trabalhadores por conta própria, trabalhadores sem remuneração e empregadores. 


\subsection{Evidências empíricas}

O mercado de trabalho brasileiro apresenta uma taxa de desemprego aberto em torno de $6 \%$ na década de 90 , segundo o Instituto Brasileiro de Geografia e Estatística (IBGE), defrontando-se com a criação de empregos que se caracteriza pela baixa qualidade. Segundo Urani (1996) uma das possíveis explicações para a taxa de desemprego ter se mostrado pouco sensível a flutuações no nível de atividade, nos primeiros 5 anos da década de 90 , pode estar na capacidade dos segmentos informais do mercado de trabalho absorverem eventuais excessos de mão-de-obra do segmento formal, ou seja, o papel compensatório do setor informal. Segundo este argumento, durante períodos de recessão econômica, o setor informal se expande absorvendo a maioria da mão-de-obra deslocada do setor formal, evitando assim, o crescimento na taxa de desemprego.

Durante a recessão no início dos anos 90 o setor informal apresenta-se como uma vigorosa fonte geradora de postos de trabalho, levando a um aumento substancial no grau de informalidade e a uma considerável estabilidade na taxa de desemprego, apesar do forte declínio no nível de atividade da economia brasileira. Urani (1996) delimita como trabalhadores formais aqueles que possuem carteira de trabalho assinada e trabalhadores informais como aqueles que não possuem carteira de trabalho assinada e trabalhadores por conta própria. Na Tabela 1, baseada em dados da Pesquisa Mensal do Emprego, observa-se que entre 1991 e 1995 a participação dos empregados com carteira de trabalho assinada na ocupação total diminuiu mais de 5 pontos percentuais no conjunto do "Brasil Metropolitano"11. Uma vez que a taxa de desemprego praticamente não aumentou durante o período, a principal contrapartida deste fenômeno foi o inchaço dos segmentos informais do mercado de trabalho: a participação dos empregados sem carteira assinada na ocupação total aumentou mais de

\footnotetext{
${ }^{11}$ A Pesquisa Mensal de Emprego (PME) é uma pesquisa domiciliar sobre a mão-de-obra e rendimento do trabalho. Os dados são obtidos de uma amostra probabilística de, aproximadamente, 36.000 domicílios situados nas regiões metropolitanas de Recife, Salvador, Belo Horizonte, São Paulo e Porto Alegre.
} 
três pontos percentuais e a dos trabalhadores por conta própria quase dois pontos. Em outras palavras, nos anos 90, o papel compensatório do setor informal como um todo tem sido muito importante.

Tabela 1. Composição da força de trabalho brasileira por posição na ocupação - 1991/95, em porcentagem. Empregado com carteira de trabalho assinada (CC), empregado sem carteira de trabalho assinada (SC), trabalhadores por conta própria (CP), empregadores (EMP) ${ }^{1}$.

\begin{tabular}{|l|cccccc|}
\hline & CC & SC & CP & EMP & $\begin{array}{c}\text { desemprego } \\
\text { aberto }\end{array}$ & $\begin{array}{c}\text { PIB - preços de } \\
1996(\mathrm{R} \$ \\
\text { milhões) }\end{array}$ \\
\hline Média de 1991 & 53,45 & 22,51 & 19,95 & 4,09 & 4,83 & 640.173 \\
Média de 1992 & 51,40 & 23,68 & 20,85 & 4,07 & 5,97 & 634.924 \\
Média de 1993 & 50,50 & 24,53 & 20,93 & 4,04 & 5,32 & 661.527 \\
Média de 1994 & 48,81 & 25,51 & 21,75 & 3,93 & 5,06 & 701.152 \\
Média de 1995 & 48,26 & 25,70 & 21,86 & 4,17 & 4,64 & 731.162 \\
\hline
\end{tabular}

TFonte: PME/IBGE, Tabela retirada de Urani (1996).

${ }^{2}$ Fonte: Conjuntura Econômica (FGV), abril/1997

${ }^{3}$ Fonte:. Relatório anual do Banco Central do Brasil - 1996

Evidências empíricas indicam que o setor informal é mais significativo quantitativamente e representa baixos níveis de renda nas regiões menos desenvolvidas. Segundo Fernandes (1996), a participação dos empregados sem carteira de trabalho assinada, no conjunto de empregados, em 1986, era de $28 \%$ na Região Sudeste, 37,6\% na Região Norte e Centro-Oeste, e 42,7\% na Região Nordeste.

Estudos do PREALC (1978), citados por Cacciamali (1982), apresentam evidências empíricas sobre a magnitude e composição do setor informal em diversos países da América Latina, a partir dos quais afirma-se que em regiões relativamente mais atrasadas do ponto de vista de consolidação da estrutura de produção capitalista, existe, em geral, maior espaço econômico para trabalhadores autônomos dedicados à manufatura de bens de consumo tais como alimentos, calçados, móveis e utilidades domésticas. Já em regiões mais desenvolvidas, os produtores informais 
concentram-se relativamente mais em atividades do setor terciário. Entretanto, indiferente ao grau de desenvolvimento da região, à medida que o mercado ocupado pelo setor formal se amplia e a tecnologia fixa níveis de produtividade social que permite a exploração dos mercados em bases capitalistas, a produção informal é substituída pela produção formal mas, não necessariamente, extingue-se. O movimento relevante é que a produção realizada em moldes capitalistas tem o poder de destruir determinadas atividades informais num determinado momento e local e, simultaneamente, criar e recriar outras. Portanto, "O setor informal tem que ser analisado em função do nível de desenvolvimento alcançado e do vigor do padrão, do ritmo de expansão e reprodução capitalista, já que seu espaço se reduz e se amplia e sua composição se altera em função do quadro e do caminho do desenvolvimento econômico-social"' (Cacciamali, 1982).

Camargo (1989) afirma que no setor de prestação de serviços as relações de trabalho são relativamente mais informais, com maior participação relativa de mão-de-obra autônoma, sem relação de trabalho assalariado. Este autor define em seu estudo como sendo segmento formal do mercado de trabalho, aquele composto por trabalhadores assalariados, com ou sem carteira de trabalho, ou seja, aquele no qual ocorre assalariamento da força de trabalho; e, como segmento informal aquele composto pelos trabalhadores por conta própria e trabalhadores de empresas familiares os quais não são assalariados. Neste segmento não prevalece a relação de trabalho assalariada. Portanto, há um certo consenso entre os autores de que, no setor secundário, há uma forte predominância de firmas tipicamente capitalistas, enquanto no setor terciário, embora o segmento mais importante deste setor seja formado por produtores tipicamente capitalistas, há relativamente maior espaço econômico para ser ocupado e explorado por atividades informais.

Uma das principais conclusões do estudo empírico feito por Cacciamali (1982) no Município de São Paulo, utilizando dados primários coletados em 
804 domicílios no ano de 1980, é a seguinte: o setor informal ${ }^{12}$ apresenta duplo caráter: constitui-se tanto em atividades de rendas relativamente altas e melhores condições de trabalho, quando comparados com o conjunto de postos de trabalho assalariados, como também em única alternativa de sobrevivência para determinados indivíduos. O primeiro conjunto de atividades está associado principalmente a serviços qualificados, mercados cativos ou dirigidos para demandas de alto nível de renda ou salário. Destacam-se, neste caso, pequenos comerciantes, prestadores de serviços e técnicos, cuja remuneração, caso se transformassem em assalariados, seria, em geral, inferior à atual. $\mathrm{O}$ segundo conjunto de atividades informais é constituído de atividades precárias, instáveis, ocasionais, cujos níveis de renda, em geral baixos, mal conseguem suprir as necessidades mínimas do trabalhador que as exerce. Este setor constitui-se, assim, de fonte alternativa de emprego para aqueles que possuem tais qualificações e não têm meio de vida e/ou por opção e/ou por não serem absorvidos de forma regular em atividades produtivas formais.

No entanto, o fato de o setor informal exigir, para a ocupação de parte substancial do espaço econômico que lhe é permitido, um montante de capital inicial e/ou comando de instrumentos de trabalho e qualificação e/ou experiência profissional, pode impedir o acesso de contigentes desprovidos dessas qualidades. Assim, a maior parte destes irá se empregar em trabalhos braçais ou em serviços gerais, seja como assalariados (ajudantes gerais na indústria de transformação e construção civil, carregadores, serviços gerais de limpeza, de alimentação, de segurança), como ajudantes de trabalhadores autônomos ou no serviço doméstico. Esta parcela, contudo, não constitui o setor informal como um todo. Portanto, mesmo em atividades precárias, os trabalhadores autônomos não obrigatoriamente percebem rendas relativamente baixas quando comparadas às de postos de trabalho assalariado, como por exemplo operários não qualificados em geral, da construção civil em particular, mensageiros e ajudantes em

${ }^{12}$ Cacciamali delimita os setores formal e informal da economia com base na Abordagem subordinada e intersticial. 
geral nos escritórios e balconistas no comércio. Em outras palavras, o fato de conjuntos de trabalhadores que auferem baixo nível de renda participarem do setor informal e, em determinadas circunstâncias, serem até maioria relativa do setor, não implica que a maior parte dos trabalhadores de rendimentos relativamente inferiores está no setor informal. As informações sobre a distribuição da renda entre trabalhadores inseridos no setor formal e informal da economia, no ano de 1980 para o Município de São Paulo, analisadas por Cacciamali, mostram que, os baixos níveis de renda eram características entre todos os segmentos de trabalhadores e que parcelas substanciais de indivíduos e famílias, que percebiam baixos níveis de renda situavam-se também no setor formal. Portanto, os trabalhadores com baixos níveis de renda devem estar distribuídos nos setores formais e informais da economia.

\section{Estudos realizados pelo PREALC (Brasil (1972), Equador} (1970), El Salvador (1974), México (1970), Paraguai (1973) e República Dominicana (1973)), os quais foram detalhadamente analisados por Souza ${ }^{13}$ (1980), mostram que o emprego feminino é muito mais importante no setor informal que no formal. Isso poderia ser conseqüência da inclusão do serviço doméstico dentro das atividades informais; entretanto, mesmo que fosse excluída esta ocupação a conclusão era a mesma. Por outro lado, observava-se também que, em todos os casos, o setor informal concentra os trabalhadores mais jovens e os mais velhos. Em Assunção e São Salvador, pôde se comprovar que os mais jovens eram geralmente empregados e operários (no serviço doméstico e em pequenas empresas), enquanto os mais velhos eram preponderantemente trabalhadores por conta própria. Foi detectado também em todos os casos analisados que o setor informal concentrava os menos educados e especialmente os funcionalmente analfabetos (menos de três anos de escolaridade). Observou-se também que, para

\footnotetext{
${ }^{13}$ Souza parte da interpretação dada pelo PREALC para definir setor informal. Assim, para Souza "o setor informal está constituído pelo conjunto de empresas elou pessoas ocupadas em atividades nãoorganizadas, que utilizam processos tecnológicos simples e que além disso estão inseridas em mercados competitivos, ou na "base" da estrutura produtiva no caso dos mercados oligopólicos concentrados. Dadas estas características, sua capacidade de acumulação e, finalmente, de expansão será restringida" (Souza, 1980, p. 135).
} 
Assunção, São Salvador e São Domingos existem pessoas ocupadas no setor informal que recebem rendas superiores às recebidas por alguns grupos empregados no setor formal e que por este motivo não teriam motivação para trocar sua ocupação atual por uma do setor formal (por exemplo, no caso de um trabalhador por conta própria bem sucedido no comércio estabelecido informal, com relação a um empregado num estabelecimento moderno do mesmo setor). Entretanto, a informação também indica claramente que esta não é a situação da grande maioria dos ocupados no setor informal. Mais ainda: a evidência empírica indica a existência de segmentação no mercado de trabalho com a consequiente diferenciação de rendas para pessoas com os mesmos atributos pessoais, ocupadas nos seus distintos segmentos. Para as três cidades, observase diferenças significativas de rendas entre setor informal e formal, mesmo tomando categorias tão homogêneas como pessoas com igual escolaridade, sexo e idade, ou pessoas com igual escolaridade, sexo e categoria ocupacional, mesmo controlando esta última variável por ramo de atividade (nos casos da indústria manufatureira e comércio estabelecido). Assim, por exemplo, nas três cidades, os homens em idade de maior atividade, com quatro a seis anos de escolaridade, ocupados no setor informal não doméstico, recebem cerca de $60 \%$ da renda obtida pelas pessoas com idênticas características ocupadas no setor formal privado.

Webb (1974), citado por Souza (1980), estimou para o caso do Peru as distribuições de renda prevalecentes em cada setor, mostrando as superposições que existem entre elas. Observou-se claramente que as pessoas de maior renda dentro do setor informal recebem em média mais que os grupos menos favorecidos dentro do setor formal.

Pero (1994) analisou como as diferenças salariais entre empregados com e sem carteira de trabalho assinada e o grau de formalização do mercado de trabalho metropolitano brasileiro (proporção dos empregados com carteira de trabalho assinada) variam e se correlacionam de acordo com: (1) a qualificação dos trabalhadores, ou seja, por escolaridade e idade; (2) a região de residência e (3) a 
evolução temporal. A autora escolheu a posse ou não da carteira de trabalho como indicador da segmentação do mercado de trabalho baseada na idéia, aceita pela maioria dos pesquisadores da área, de sua posse estar ou não vinculada à indicação de "bons" e "maus" empregos na economia. A idéia de que são os empregados com carteira de trabalho assinada quem adquirem "bons" empregos na economia está relacionada ao fato de os trabalhadores com carteira terem acesso a uma série de vantagens pecuniárias e não-pecuniárias, às quais não teriam acesso caso fossem empregados sem contrato formal de trabalho.

A pesquisadora usou como fonte de dados em seu estudo a PNAD, abrangendo o período de 1981 a 1989, para as nove regiões metropolitanas brasileiras. Restringiu sua amostra à população economicamente ativa urbana ocupada, excluindo as pessoas que declararam trabalhar em atividades agrícolas exercidas em áreas urbanas; limitando o universo de análise aos empregados com e sem carteira de trabalho assinada do setor privado e aos homens com menos de 12 anos de estudo. A partir dos dados de 1988 verificou que apenas 55\% da força de trabalho ocupada eram constituídos de empregados com relações formais de trabalho.

A partir da análise dos dados, Pero chegou às seguintes conclusões (aqui são apresentadas somente as mais importantes e com maior correlação com o presente trabalho):

- Constatou que o grau de formalização cresce do Norte-Nordeste para o Centro-Sul da seguinte forma: em Belém e Fortaleza está abaixo de 70\%; Recife apresenta um nível de formalização de 71\%; Salvador, Belo Horizonte e Rio de Janeiro apresentam níveis intermediários de formalização, variando de 75 a 80\%; São Paulo tem um grau de formalização de $83 \%$ e, o grau de formalização em Curitiba e Porto Alegre gira em torno de $85 \%$. Verificou então que, assim como o grau de desenvolvimento cresce do Norte para o Sul, o grau de formalização também o faz. 
- Constatou, para o período analisado (1981/89), que o grau de formalização cresce com o nível educacional dos trabalhadores, passando de $71 \%$ entre os trabalhadores sem instrução, para 88\%, entre aqueles com 09 e 11 anos de estudo. Verificou também que o nível de renda é maior para grupos com mais instrução, os salários crescem monotonicamente com a escolaridade dos trabalhadores.

6 - Quanto ao grau de formalização por faixa etária $(0-25,26-35$,
$36-45,46-44$ e $>55$ anos) observou que o nível mais alto de formalização encontra-se entre os trabalhadores com idade entre 26 e 45 anos, aproximadamente $88 \%$, enquanto os grupos mais informais estão presentes nas faixas extremas (70\%). O nível salarial atinge seu ponto mais alto no grupo de trabalhadores com idade entre 46 e 55 anos, enquanto o grau de formalização atinge seu pico na faixa etária anterior (36-45 anos).

Resumindo, a autora concluiu que "o grau de informalidade tende a ser maior entre os trabalhadores menos experientes, idosos e menos educados. Esta evidência é compatível com a visão de que os contratos formais de trabalho são considerados uma fonte de proteção para uma fração da força de trabalho, prioritariamente os trabalhadores com idade entre 35 e 55 anos e os mais bem educados, e os contratos informais como uma fonte de emprego para aqueles que não foram demandados pelos empregadores que oferecem empregos com contrato formal de trabalho" (Pero, 1994).

- Pero estudou ainda o diferencial salarial entre os empregados com e sem carteira de trabalho. Constatou que os empregados com contrato formal de trabalho recebem em média o dobro daqueles que não possuem vínculo empregatício formal. Entretanto, mostrou que pouco mais da metade desse diferencial pode ser explicado por diferenças entre trabalhadores com e sem carteira de trabalho no que diz respeito a características individuais e produtivas, tais como escolaridade, idade e região de residência. Verificou que os trabalhadores sem carteira de trabalho pertencentes ao 
mesmo grupo educacional e etário e mesma região metropolitana ganham um salário $45 \%$ menor do que aqueles que pertencem a este mesmo compartimento do mercado de trabalho, o que evidencia uma forte segmentação no mercado de trabalho metropolitano brasileiro.

- Em relação às estimativas das diferenças salariais entre empregados com e sem carteira de trabalho assinada por região metropolitana Pero constatou que em Belém e Fortaleza observava-se diferenciais de salário em torno de $20 \%$, representando as regiões com mais baixo hiato salarial e mais alto grau de informalidade; no Rio de Janeiro, Curitiba e Porto Alegre observava-se diferencial salarial de aproximadamente 30\%; assim, as regiões que apresentam os menores níveis de informalidade (Curitiba e Porto alegre) apresentaram diferenciais de salário em níveis intermediários; as demais regiões apresentaram um hiato salarial entre 45 e $55 \%$, sendo o mais alto representado pela região metropolitana de São Paulo. Isto leva a crer que o grau de segmentação é maior nas regiões metropolitanas mais desenvolvidas e que a carteira de trabalho tende a proteger os trabalhadores residentes nas regiões mais desenvolvidas do país.

- Pero demostrou ainda que o hiato salarial entre os empregados com e sem carteira de trabalho cresce com o nível educacional dos trabalhadores, revelando que os retornos salariais à escolaridade dos empregados com carteira são relativamente maiores do que os retornos dos empregados sem relações formais de trabalho e, os empregos com contrato formal de trabalho protegem prioritariamente os trabalhadores com maior nível de escolaridade.

Marcouiller et al. (1997) usaram dados do setor urbano de 3 países: El Salvador, México e Peru, para identificar o tipo de indivíduos que trabalham no setor informal da economia e, verificar se os trabalhadores do setor informal recebem salários mais baixos que os trabalhadores do setor formal (comparando-se trabalhadores com iguais características individuais e produtivas). Seis mil domicílios foram 
pesquisados em El Salvador em 1990, 11.000 no México em 1990 e 5.000 no Peru entre julho de 1985 e maio de 1986.

Os autores usaram dois critérios para definir o setor informal: o tamanho da firma e o sistema de previdência social. Trabalhadores informais, pelo critério do tamanho da firma, seriam aqueles que são empregados por conta própria e aqueles que trabalham em firmas com 5 ou menos empregados. Pelo critério da previdência social, são trabalhadores formais aqueles que recebem apólice de previdência social ou pagam taxas de previdência social. Foram excluídos empregados domésticos e trabalhadores em empresas familiares sem rendimento. O estudo mostrou que os 3 países possuem um setor informal bastante significativo. Pelo critério do tamanho da firma o setor informal correspondia a 47,9, 57,5 e 30,8\% do total das atividades econômicas em El Salvador, Peru e México respectivamente. Pelo critério da previdência social o setor informal correspondia a 62,$8 ; 61,8$ e $43,2 \%$ do total das atividades econômicas em El Salvador, Peru e México respectivamente.

A seguir são apresentadas as conclusões mais importantes deste trabalho, (inferidas a partir da análise dos setores, formal e informal, adotando-se o critério da previdência social):

- Os pesquisadores detectaram em El Salvador e Peru maior concentração das mulheres no setor informal, porém observaram o contrário no caso do México. Verificaram também, para todos os países, que os trabalhadores mais jovens e os mais velhos concentram-se mais no setor informal, contudo, os dois grupos possuem papéis diferentes dentro do setor informal; trabalhadores muito jovens concentram-se como assalariados em pequenas firmas, enquanto trabalhadores idosos são trabalhadores por conta própria ou possuem pequenos negócios. Constataram que a propensão a ser trabalhador informal declina com o aumento nos anos de estudo. Tal assertiva é válida para os 3 países em questão. 
- Cinco indústrias concentram aproximadamente $2 / 3$ do emprego do setor informal em cada país: comércio varejista, construção, manufatura de roupas e calçados, transportes e serviços pessoais.

- A distribuição das horas trabalhadas por semana difere entre os setores. As extremidades da distribuição de horas trabalhadas por semana concentram-se mais no setor informal que no setor formal. No Peru, 23\% (7\%) das mulheres (homens) no setor informal trabalham menos que 20 horas por semana, comparada com, apenas $8 \%(4 \%)$ das mulheres (homens) no setor formal. Igualmente, $14 \%$ (17\%) das mulheres (homens) na força de trabalho informal trabalham mais que 65 horas por semana, comparada com somente $2 \%(8 \%)$ das mulheres (homens) engajada na força de trabalho formal.

Marcouiller et al. (1997) estimaram equações de salários para os 3 países e para homem e mulher separadamente, para os setores formal e informal. Como variável dependente utilizou o logaritmo do salário/hora, como variáveis independentes foram usadas anos de escolaridade, segundo grau completo, experiência, experiência ao quadrado, seis variáveis binárias para indústrias (agricultura, comércio, manufatura, construção, transportes e comunicação e, serviços) e variáveis binárias para residência em San Salvador, Lima, Guadalajara e Monterrey. Todos os coeficientes estimados apresentaram os sinais esperados.

A partir das equações de salários estimadas, os autores verificaram a existência de segmentação nos dois setores (formal e informal). Para medir os diferenciais de salário entre os setores pesquisados utilizaram o modelo econométrico desenvolvido por Blinder (1973) e Oaxaca (1973). Essencialmente este modelo assume que na ausência de segmentação os efeitos estimados das características individuais dos trabalhadores são idênticos para cada grupo (este modelo é apresentado na seção 3.3 deste trabalho). Os resultados por eles encontrados são apresentados na Tabela 2. 
Tabela 2. Diferenciais de salário total e diferencial de salário inexplicado em El Salvador (1990), Peru (1986) e México (1990).

\begin{tabular}{|lcc|}
\hline & mulheres & homens \\
\hline EI Salvador & & \\
log do salário médio no setor formal & 1,60 & 1,59 \\
log do salário médio no setor informal & 0,64 & 0,88 \\
diferença das médias dos log salários & 0,96 & 0,71 \\
diferença salarial inexplicada (CF) & 0,48 & 0,26 \\
diferença salarial inexplicada (CI) & 0,38 & 0,36 \\
Peru & & \\
log do salário médio no setor formal & 1,90 & 1,92 \\
log do salário médio no setor informal & 1,02 & 1,42 \\
diferença das médias dos log salários & 0,89 & 0,50 \\
diferença salarial inexplicada (CF) & 0,31 & 0,14 \\
diferença salarial inexplicada (CI) & 0,56 & 0,12 \\
México & & \\
log do salário médio no setor formal & 1,12 & 1,20 \\
log do salário médio no setor informal & 1,04 & 1,17 \\
diferença das médias dos log salários & 0,09 & 0,02 \\
diferença salarial inexplicada (CF) & $-0,07$ & $-0,11$ \\
diferença salarial inexplicada (CI) & $-0,09$ & $-0,13$ \\
\hline CF usa a média das características dos trabalhadores do setor formal como ponderação (ver equação \\
17 na seção 3.3). \\
${ }^{2}$ Cl usa a média das características dos trabalhadores informais como ponderação (ver equação 18 na seção 3.3).
\end{tabular}

A diferença salarial em El Salvador é substancial. A Tabela 2 mostra que a média do log da taxa do salário para a mulher em El Salvador no setor formal é 0,96 (diferencial de salário total) mais alto que no setor informal. Parte desta diferença pode ser explicada pelas diferenças intersetoriais na composição da indústria e nas características individuais médias dos trabalhadores, o correspondente a 0,48 (50\% do total do diferencial) - usando a média das características dos trabalhadores do setor formal como ponderação (componente $C$ da equação 17 apresentada no capítulo 3) e $0,58(60,4 \%$ do total do diferencial) - usando a média das características dos trabalhadores informais como ponderação (componente $\mathrm{C}$ da equação 18 do capítulo 3 ). $O$ resto da diferença, $0,48(0,38), 50 \%$ e $39,6 \%$ respectivamente, dependendo do esquema de ponderação, é a diferença salarial não explicada, ou seja, é a diferença salarial devido a segmentação do mercado de trabalho. A média do log da taxa de salário 
dos homens em El Salvador no setor formal é 0,71 mais alto que a média do log da taxa do salário no setor informal. Parte desta diferença salarial, 0,26 (0,36), 36,7\% e 50,7\%, respectivamente, conforme o esquema de ponderação, não pode ser explicada pelas diferenças das características pessoais observadas.

A Tabela 2 mostra que as diferenças salariais são relativamente maiores para a mulher peruana $(0,89)$, mas também bastante significativo para os homens $(0,50)$. Para as mulheres, as características pessoais explicam somente metade da diferença no log da taxa de salário, e para os homens um quarto da diferença permanece inexplicada. No México em 1990, o total das diferenças salariais eram explicados pelas diferenças intersetoriais na composição da indústria e nas características individuais médias dos trabalhadores. Este resultado é indicado pelo sinal negativo obtido na diferença salarial inexplicada.

Barros e Varandas (1987) constataram que o grupo de trabalhadores com carteira de trabalho assinada recebe em média salários superiores aos daqueles sem carteira assinada. Estes diferenciais poderiam ser explicados por maiores níveis de escolaridade e maior experiência dos trabalhadores com carteira, o que os tornariam mais produtivos. Entretanto, Barros, Reis e Rodrigues (1990) mostram, para vários anos, que persistem um diferencial, da ordem de 15 a 20\%, mesmo quando vários atributos observáveis são controlados. Mesmo que diferenças nos atributos não observáveis possam explicar este diferencial, sua persistência ao longo do tempo tende a comprovar a hipótese de alguma segmentação vinculada à posse de carteira de trabalho assinada.

Savedoff (1988) mostra em seu estudo a persistência de significativos diferenciais de salários entre as regiões metropolitanas do país, mesmo após controlar por diferenças de custo de vida, por características pessoais e pela estrutura setorial e de ocupações. A interpretação do autor para estes diferenciais de salário é que eles refletem o fato de que a produção de bons e maus empregos é 
diferenciada entre as regiões, o que não é adequadamente captado pelas variáveis setoriais utilizadas.

Há poucos estudos estimando os determinantes da participação e rendimentos nos setores formal e informal brasileiros. Basicamente existem dois trabalhos: Tiefenthaler (1994) e Kassouf (1997).

Tiefenthaler (1994) estudou os determinantes da participação da força de trabalho do homem e da mulher, casada e solteira, na força de trabalho brasileira e os determinantes dos salários para os setores formais e informais da economia. Entretanto, analisou apenas os resultados obtidos para as mulheres (casadas e solteiras) . A autora delimita como trabalhadores formais aqueles que possuem carteira de trabalho assinada, e trabalhadores informais como aqueles que não possuem carteira de trabalho assinada e trabalhadores por conta própria. Os dados usados neste estudo foram coletados de 70.777 domicílios brasileiros (301.088 indivíduos) no último trimestre de 1989 pela Comissão Econômica Para a América Latina (CEPAL).

Tiefenthaler constatou em suas análises que: (a) apesar de estar aumentando a participação feminina na força de trabalho, a taxa de participação do homem é ainda maior e os ganhos salariais do homem são maiores, a diferença de salários é maior entre os empregados formais (mulher recebe $70,3 \%$ do salário dos homens) que entre os empregados do setor informal $(85,2 \%)$ e os trabalhadores por conta própria (70,5\%); (b) os salários são, em média, maiores para homens e mulheres no setor formal que no setor informal; (c) as mulheres concentram-se mais nos empregos informais e, os homens nos empregos formais (aqui a autora considera os trabalhadores que são empregados, desconsiderando os conta-própria), a preferência das mulheres pelo setor informal pode, segundo a autora, ser explicada pela facilidade de entrar e sair do local de trabalho e maior flexibilidade no setor informal que no setor formal; (d) existem diferenças importantes entre as regiões altamente industrializadas e modernas (central, sul e sudeste) e regiões as quais possuem grande dependência de atividades agrícolas 
(norte e nordeste), as regiões norte e nordeste possuem menores rendas, salários, níveis de escolaridade que o resto do Brasil.

As conclusões mais importantes obtidas a partir da análise econométrica realizada por Tiefenthaler são as seguintes:

- As variáveis idade e escolaridade têm efeitos positivos sobre a participação da força de trabalho feminina em todos os setores, os efeitos da escolaridade são mais fortes no setor formal.

- As variáveis utilizadas como proxies da riqueza - renda não salarial, casa própria e salário do marido - interferem negativamente na participação da mulher nos mercados de trabalho formal e informal.

- A presença de crianças pequenas nos domicílios têm um efeito negativo sobre a participação da mulher no mercado de trabalho, sendo que este efeito é mais forte no setor formal da economia, o efeito negativo é menos intenso no segmento dos trabalhadores por conta própria.

- Escolaridade e experiência têm efeito positivo e significativo nos rendimentos para o homem, mulher casada e solteira. Os maiores retornos à escolaridade foram encontrados para as mulheres no setor informal da economia, no entanto, mulheres com maior nível de escolaridade participam proporcionalmente mais no setor formal.

- Os diferenciais de rendimentos do trabalho entre homens e mulheres estão mais fortemente relacionados à discriminação que à efetiva capacidade de trabalho das mulheres. Nos segmentos formal e conta própria entre 81 e $89 \%$ dos diferenciais de salários são atribuídos à discriminação, enquanto no setor informal (onde Tiefenthaler considerou apenas trabalhadores que não possuem carteira de trabalho assinada) entre 72 e $75 \%$ do diferencial são devidos à discriminação. 
Kassouf (1997) analisou os determinantes da participação e rendimentos para o setor formal e informal do mercado de trabalho brasileiro ${ }^{14}$, realizando comparações entre os dois setores e entre homens e mulheres. Escolaridade, idade, número de crianças no domicílio, idade destas crianças, raça, renda não-salarial e regiões foram alguns dos fatores considerados como determinantes da participação no mercado de trabalho. Como determinantes dos rendimentos no mercado de trabalho considerou-se fatores como escolaridade, idade, raça e regiões. Os dados utilizados nesta pesquisa são da Pesquisa Nacional sobre Saúde e Nutrição, empreendida pelo IBGE, Instituto de Pesquisa Econômica Aplicada (IPEA) e Instituto Nacional de Saúde e Nutrição (INAN), compondo-se de aproximadamente 63.000 indivíduos entrevistados em 17.920 domicílios brasileiros.

A análise mostrou que: (a) existem aproximadamente $13 \%$ e $3 \%$, homens e mulheres, respectivamente, a mais de trabalhadores no setor informal que no setor formal; (b) nos dois setores os rendimentos das mulheres são de 20 a $30 \%$ mais baixos que dos homens; (c) os rendimentos são mais baixos no setor informal, aproximadamente $50 \%$ dos rendimentos recebidos pelo setor formal; (d) a média de experiência no setor informal é maior que no setor formal, o que é consequiência do mais alto nível de escolaridade dos trabalhadores formais; (e) regiões sudeste e sul, bem como setor urbano, possuem mais trabalhadores no setor formal que no setor informal, e, nas regiões norte, nordeste e centro-oeste existem mais trabalhadores informais que formais; (f) trabalhadores de cor branca predominam no setor formal, enquanto trabalhadores mulatos concentram-se no setor informal da economia.

As principais conclusões obtidas a partir da análise econométrica feita por Kassouf foram:

\footnotetext{
${ }^{14}$ Trabalhadores informais foram caracterizados neste trabalho como sendo aqueles que não pagam previdência social.
} 
- a presença de crianças pequenas nos domicílios reduz a participação das mulheres no mercado de trabalho. Por outro lado, a presença de crianças nos domicílios aumenta a necessidade da participação do homem no mercado de trabalho. Outro resultado interessante é o seguinte: a presença de adolescentes do sexo feminino nos domicílios aumenta a participação das mães no mercado de trabalho, pois estas adolescentes podem substituir a mãe nos cuidados com as crianças. Em consequiência destes fatos, o resultado é a maior participação do chefe do domicílio em comparação à participação da esposa e filhos.

- Quando se relaciona participação no mercado de trabalho, ou rendimento, e experiência no trabalho observa-se uma relação parabólica. Pela teoria do capital humano, as oportunidades de encontrar trabalho e os rendimentos aumentam quando a pessoa ganha experiência até atingir um ponto no qual começa a ocorrer um processo de depreciação do capital humano, como a perda de habilidades decorrente do envelhecimento do indivíduo.

- Ecolaridade afeta positivamente a participação no mercado de trabalho, exceto para homens que trabalham no mercado de trabalho informal (cuja equação mostrou coeficiente obtido para escolaridade negativo e não significativo). Todas as equações de rendimento estimadas mostraram efeito positivo e altamente significativo para a variável escolaridade.

- As funções rendimentos estimadas mostraram que os trabalhadores do setor formal recebem salários mais altos nas regiões sudeste, sul, centro-oeste e norte que na Região Nordeste. O mesmo acontece com trabalhadores formais no setor urbano, os quais obtêm rendimentos superiores àqueles obtidos por trabalhadores no setor rural. Enquanto os homens informais recebem salários maiores nas regiões menos desenvolvidas (Norte e Nordeste) e auferem maiores níveis de rendimento nas regiões rurais. 
- O setor formal apresentou maior retorno aos investimentos em treinamento e escolaridade sobre os rendimentos do que o setor informal. Em trabalhos formais, os efeitos da experiência e escolaridade nos rendimentos para os homens são maiores do que para as mulheres. Contudo, em trabalhos informais as mulheres obtêm maiores retornos que os homens.

- Foram calculadas as idades em que os rendimentos atingem o valor máximo na vida do trabalhador variando os níveis de escolaridade, 4, 8 e 12 anos. A variação da idade, quando varia o nível de escolaridade, não é muito grande em ambos os setores, para os dois sexos, variando de 42 a 48 anos, sendo que a maior variação de idade ocorre para os homens dentro do setor informal, o que indica que os trabalhadores com mais anos de escolaridade atingem o pico de rendimento mais cedo.

- Kassouf verificou a existência de uma grande discriminação salarial por gênero em ambos os setores da economia, formal e informal, sendo maior a discriminação no setor informal que no setor formal. No setor informal a mulher recebe $27 \%$ menos que o homem. O estudo demonstrou que na ausência de discriminação as mulheres teriam um acréscimo de renda em torno de $70 \%$, o que tornaria o salário das mulheres $26 \%$ maior que dos homens. No setor informal o salário das mulheres é $23 \%$ inferior ao salário dos homens. Neste caso, na ausência de discriminação o salário das mulheres dobraria de valor, o que tornaria o salário das mulheres $67 \%$ maior que o salário dos homens. Assim, observou-se que o total do diferencial de rendimentos era devido à discriminação em ambos mercados de trabalho. Este resultado foi obtido pois a metodologia empregada permite calcular o rendimento hipotético para as mulheres caso essas tivessem a mesma estrutura dos homens (coeficientes estimados das equações dos homens). Após este cálculo o diferencial de rendimentos que permanecer entre o rendimento do homem e o rendimento hipotético da mulher é atribuído somente a diferenças nas características produtivas. $O$ aumento nos rendimentos das mulheres reflete a porção devida à discriminação. Como o estudo demonstrou que na ausência de discriminação os rendimentos das mulheres superaria os rendimentos dos homens 
concluiu-se que todo o diferencial de rendimentos era devido à discriminação. Kassouf também concluiu que 20\% do diferencial de rendimentos observado em 1989 entre os mercados de trabalho formal e informal eram devido à segmentação do mercado de trabalho, sendo o restante $(80 \%)$ do diferencial devido às diferenças nas características individuais e produtivas dos trabalhadores.

Fernandes (1996a) estimou, por máxima verossimilhança, a probabilidade do indivíduo situar-se no setor não-regulamentado (trabalhador sem carteira de trabalho assinada) usando o modelo lógite multinomial. Utilizou dados de empregados do setor privado com mais de 10 anos residentes em uma das nove regiões metropolitanas brasileiras coletados pela PNAD em 1989; sua amostra conta com 28.393 indivíduos assalariados. Os resultados obtidos demonstraram que a probabilidade do indivíduo situar-se no mercado de trabalho (não-) regulamentado (de) cresce com os anos de estudo e, a probabilidade de um indivíduo se situar no mercado de trabalho regulamentado é inicialmente crescente com a idade, atinge um máximo e, a partir daí, decresce, sendo que a idade em que a probabilidade de um indivíduo encontrar um emprego com carteira de trabalho assinada é máxima aos 41,7 anos. Os resultados demonstraram que a probabilidade de se encontrar um emprego com registro em carteira é maior para os homens do que para as mulheres e decresce na seguinte ordem nas regiões: Curitiba, Porto Alegre, São Paulo, Belo Horizonte, Salvador, Rio de Janeiro, Recife, Fortaleza e Belém.

Fernandes (1996b) encontrou diferencial de salários entre trabalhadores com e sem registro em carteira da ordem de 30\% para o Brasil, de $19 \%$ em Porto Alegre e de $45 \%$ em Recife. Observou que em média os homens ganham 55,7\% a mais do que as mulheres e que os salários crescem com aumentos nos anos de estudo e com a idade, sendo que o máximo rendimento é atingido aos 54,8 anos de idade, a partir da qual os rendimentos passam a decrescer. São Paulo apresentou o maior nível salarial, seguido por Curitiba, Porto Alegre, Belo Horizonte, Rio de Janeiro, Salvador, Belém, Fortaleza e Recife. O diferencial de salários encontrados a favor de São Paulo com 
relação a Recife foi de $114 \%$. Observou ainda que os diferenciais eram menores para os homens em relação às mulheres e que não se diferenciavam muito entre as regiões.

É amplamente conhecido que no Brasil, bem como em outros países, existe uma substancial desigualdade nos rendimentos devido a cor dos indivíduos. Os diferenciais de rendimento entre trabalhadores brancos e não-brancos no Brasil, apesar de terem mostrado uma redução nos últimos 5 anos, ainda são significativos. Em 1990 os rendimentos médios dos homens pretos e pardos eram, respectivamente, $63 \%$ e $68 \%$ dos rendimentos dos brancos. Em 1995 essas porcentagens passam para $44 \%$ e $51 \%$, sendo a situação da mulher preta e parda em relação a branca bastante semelhante. Esse diferencial de renda decorre de variações nas características dos trabalhadores, como escolaridade e experiência, além de diferenças no setor de atividade produtiva (primário, secundário e terciário) e região em que trabalha, e até se o empregado é ou não sindicalizado. Entretanto, mesmo controlando todos esses fatores, ainda se observa diferenças significativas entre os rendimentos dos trabalhadores brancos e não-brancos, que podem ser atribuídas à discriminação. Lovell (1992), utilizando dados dos censos de 1960 e 1980, observou um aumento significativo da discriminação salarial entre brancos e afro-brasileiros nesse período. 


\section{METODOLOGIA}

\subsection{Modelos de respostas múltiplas}

Os modelos de respostas múltiplas são aqueles em que a variável dependente assume mais de dois valores, sendo esses de natureza discreta. O problema econômico apresentado neste estudo, ou seja, a decisão do indivíduo participar ou não do mercado de trabalho e em que mercado se empregar será analisado a partir deste modelo. A variável dependente, nas equações de participação no mercado de trabalho, tomará o valor 0 - se o indivíduo não trabalha, 1 - se trabalha no mercado formal, 2 - se trabalha no mercado informal e, 3 - se é empregador.

A probabilidade de ocorrência de cada resposta, de acordo com este modelo, é uma função de um conjunto de atributos dos indivíduos tais como idade, gênero, estado conjugal, número de filhos, região de residência, raça, etc.

\subsubsection{Modelo de respostas múltiplas com seletividade amostral}

Dado que uma proporção dos indivíduos da amostra não trabalham, a estimação das equações de rendimento, pelo método de mínimos quadrados ordinários, utilizando-se apenas os rendimentos dos trabalhadores, pode resultar em "viés de seletividade amostral", fazendo com que as estimativas dos parâmetros sejam inconsistentes. Para solucionar este problema, será utilizado o modelo de respostas múltiplas com viés de seletividade amostral desenvolvido por Lee (1983) e Maddala 
(1990). O procedimento descrito a seguir possibilita obter estimativas sem viés de seletividade amostral.

Considere-se o seguinte modelo de múltipla escolha com 4 categorias representadas pelo subscrito $s$ (as 4 categorias analisadas neste estudo são: não participa do mercado de trabalho $(s=0)$, trabalha no mercado formal $(s=1)$, trabalha no mercado informal $(s=2)$ ou é empregador $(s=3)$, onde cada categoria é representada por uma equação), e $N$ indivíduos representados pelo subscrito $i$ :

$$
\begin{array}{ll}
\mathrm{Y}_{s i}=X_{s i} \beta_{s}+v_{s i} & (s=0,1,2,3) \\
L_{s i}^{*}=Z_{s i} \gamma_{s}+u_{s i} & (i=1,2, \ldots, N)
\end{array}
$$

onde $X_{s i}$ e $Z_{s i}$ são as variáveis exógenas; $\mathrm{E}\left(v_{s i} \mid X_{s i}, Z_{s i}\right)=0$ e $\mathrm{E}\left(u_{s i} \mid X_{s i}, Z_{s i}\right)=0$; o rendimento $\mathrm{Y}_{s i}$ é observado somente se a $s$-ésima categoria é a escolhida. Na prática, $L_{s i}^{*}$ não é observado. O que se observa é a variável de múltipla escolha $L_{i}$ tomando valores $0,1,2$ e 3 . A $s$-ésima categoria é escolhida pelo indivíduo $i$ se $L_{i}=s$, o que acontece se e somente se,

$$
L_{s i}^{*}>\operatorname{Max} L_{j}^{*} \quad(j=0,1,2,3 j \neq \mathrm{s})
$$

ou seja, o indivíduo compara a máxima utilidade que poderá obter, dadas as 4 alternativas, e seleciona aquela que maximizará sua utilidade

Faça-se

$$
\varepsilon_{s}=\operatorname{Max} L_{j}^{*}-u_{s} \quad(j=0,1,2,3 j \neq s)
$$

Isto segue que

$$
L_{i}=s \text { se e somente se } \varepsilon_{s}<Z_{s} \gamma_{s}
$$


McFadden $(1973)^{15}$ mostrou que se (e somente se) $u_{j}(j=0,1,2,3)$ são independentemente e identicamente distribuídos com função de distribuição de probabilidade de Weibull dada por

$\mathrm{F}\left(u_{i}\right)=\exp \left(-e^{-u_{i}}\right)$

então, pode-se mostrar que o erro tem uma distribuição logística, o que conduz ao modelo denominado "lógite Multinomial":

$\operatorname{Prob}\left(\varepsilon_{s}<Z_{s} \gamma_{s}\right)=\operatorname{Prob}(L=s)=\frac{\exp \left(Z_{s} \gamma_{s}\right)}{\sum_{j} \exp \left(Z_{j} \gamma_{s}\right)}$

Desta forma, a função distribuição de $\varepsilon_{s}$ é dada por

$\mathrm{F}_{s}(\varepsilon)=\operatorname{Prob}\left(\varepsilon_{\mathrm{s}}<\varepsilon\right)=\operatorname{Prob}\left[\left(\operatorname{Max}_{j=0,1,2,3} L_{j \neq s}^{*}-u_{s}\right)<\varepsilon\right]=\frac{\exp (\varepsilon)}{\exp (\varepsilon)+\sum_{j=0,1,2,3} \exp \left(Z_{j} \gamma_{j}\right)}$

Portanto, para cada escolha $s$ nós temos o modelo

$\mathrm{Y}_{s}=X_{s} \beta_{s}+v_{s}$

onde a variável dependente $\mathrm{Y}_{s}$ é observada se e somente se a categoria $s$ é escolhida, isto é, $\varepsilon_{s}<Z_{s} \gamma_{s}$. Considere a seguinte transformação para a normalidade:

$\varepsilon_{s}^{*}=J_{s}\left(\varepsilon_{s}\right)=\Phi^{-1}\left[F_{s}(\varepsilon)\right]$

onde $\Phi(\cdot)$ é a função de distribuição normal e $J_{s}$ é qualquer função de distribuição.

is MCFADEN, D. Conditional logit analisys of qualitative choice behavior. In Frontiers in Econometrics, ed by P. Zarembka. New York: Academic Press, 1973. 
A condição $\varepsilon_{s}<Z_{s} \gamma_{s} \Leftrightarrow \varepsilon_{s}^{*}<J_{s}\left(Z_{s} \gamma_{s}\right)$, e se $v$ é normalmente distribuído temos que,

$$
\begin{aligned}
& E\left(Y_{s} \mid Y_{s} \text { é observado }\right)=E\left(Y_{s} \mid L=s\right)=E\left(Y_{s} \mid \varepsilon_{s}<Z_{s} \gamma_{s}\right)=E\left[Y_{s} \mid \varepsilon_{s}^{*}<J_{s}\left(Z_{s} \gamma_{s}\right)\right]= \\
& =X_{s} \beta+E\left[v_{s} \mid \varepsilon_{s}^{*}<J_{s}\left(Z_{s} \gamma_{s}\right)\right]=X_{s} \beta_{s}+\sigma_{s} \rho_{s} \frac{\phi\left[J_{s}\left(Z_{s} \gamma_{s}\right)\right]}{\Phi\left[\Phi^{-1}\left[F_{s}\left(Z_{s} \gamma_{s}\right)\right]\right]}
\end{aligned}
$$

onde $\phi$ é a função densidade da distribuição normal, $\sigma_{s}^{2}=\operatorname{Var}\left(v_{s}\right)$, e $\rho_{s}$ é o coeficiente de correlação entre $\nu_{s}$ e $\varepsilon_{s}^{*}$.

Portanto, a partir da equação (6) a reta de regressão pode ser escrita como:

$$
\mathrm{Y}_{s}=X_{s} \beta_{s}+\sigma_{s} \rho_{s} \frac{\phi\left[J_{s}\left(Z_{s} \gamma_{s}\right)\right]}{F_{s}\left(Z_{s} \gamma_{s}\right)}+u_{s}
$$

onde o termo $\frac{\phi\left[j_{s}\left(Z_{s} \gamma_{s}\right)\right]}{F_{s}\left(Z_{s} \gamma_{s}\right)}$ é denominado inverso da razão de Mill ou lambda.

Analisando a equação (7) é fácil observar que se a taxa de rendimento fosse estimada em função de $X$ utilizando a técnica de mínimos quadrados ordinários, somente para indivíduos que participam do mercado de trabalho, a estimativa de $\beta$ seria inconsistente, uma vez que estaria sendo omitido o segundo termo da equação (7). Entretanto, os parâmetros da equação (7) podem ser consistentemente estimados pelo método de dois estágios. No primeiro estágio, estima-se os coeficientes $\gamma_{s}$ da equação de $L_{s}$ em função de $Z_{s}$ pelo método de máxima verossimilhança (modelo lógite multinomial) utilizando-se toda a amostra, inclusive os indivíduos que não trabalham. A partir dos coeficientes $\gamma_{s}$ estimados, obtêm-se a variável lambda estimada, que será utilizada na equação de rendimentos, somente para a amostra de trabalhadores. 
Contudo, mesmo corrigindo o modelo para viés de seletividade amostral, a técnica de mínimos quadrados ordinários é ineficiente porque a variância do erro, $u$,é heterocedástica, caso o "lambda" seja observado e significativo. Baseado nisto, os desvios padrões dos coeficientes são reestimados usando a matriz de covariância assintótica apropriada (ver Maddala, 1980, pág. 278).

\subsubsection{Efeitos marginais no modelo lógite multinomial}

Considere um modelo lógite multinomial com 4 escolhas $s$ : não trabalhar $(s=0)$, trabalhar no setor formal $(s=1)$, trabalhar no setor informal $(s=2)$ e, ser empregador $(s=3)$. O modelo é:

$$
P_{s}=\operatorname{Prob}\left(L_{i}=s\right)=\frac{e^{\gamma_{s} z_{s}}}{\sum_{j=0}^{3} e^{\gamma_{j} z_{j}}}
$$

Estimando o modelo, será encontrado um conjunto de coeficientes que não são, entretanto, fáceis de interpretar. Para obter os efeitos marginais primeiramente assume-se que $\gamma_{0}=0$. As probabilidades são, portanto,

$$
\operatorname{Prob}\left(L_{i}=s\right)=\frac{e^{\gamma_{s}^{\prime} z_{s}}}{1+\sum_{j=1}^{3} e^{\gamma_{j} z_{j}}} \quad \text { para } \quad s=1,2,3
$$

$\mathrm{e}$

$$
\operatorname{Prob}\left(L_{i}=0\right)=\frac{1}{1+\sum_{j=1}^{3} e^{\gamma_{j} z_{j}}}
$$


Diferenciando as equações acima encontra-se os efeitos marginais, que são:

$$
\frac{\partial P_{s}}{\partial Z_{i}}=P_{s}\left[\gamma_{s}-\sum_{j=0}^{j} P_{j} \gamma_{j}\right]=P_{s}\left[\gamma_{s}-\bar{\gamma}\right]
$$

Note que os sinais dos efeitos marginais podem ser diferentes dos sinais dos coeficientes estimados ${ }^{16}$.

\subsection{O efeito da discriminação e da segmentação do mercado de trabalho sobre os rendimentos}

É amplamente conhecido que no Brasil, bem como em outros países, existe uma substancial desigualdade nos rendimentos por gênero e por cor. Um importante problema diz respeito a apresentar qual o diferencial nos rendimentos é derivado de variações nas características produtivas individuais tais como habilidades, escolaridade, experiência e idade e qual a parte no diferencial de rendimentos refere-se ao efeito da discriminação. Será considerada o emprego de uma técnica econométrica para medir os efeitos da discriminação sobre os rendimentos, de modo a mensurar a desigualdade nos rendimentos por gênero, e para verificar a existência de segmentação entre os mercados de trabalho formal e informal, e empregadores.

A existência de segmentação no mercado de trabalho é definida como sendo o conjunto de situações em que existem trabalhadores com o mesmo potencial produtivo recebendo sistematicamente rendimentos diferentes por participarem de mercados de trabalho distintos (formal, informal e empregadores - para o presente caso). A discriminação existe quando o mercado de trabalho remunera

\footnotetext{
${ }^{16}$ Para maiores detalhes sobre a interpretação dos efeitos marginais no modelo lógite multinomial, ver Greene (1993, cap. 21).
} 
distintamente trabalhadores igualmente produtivos com base em atributos não produtivos, como, por exemplo, cor e gênero.

"O modelo econométrico mais usado para medir os efeitos da discriminação sobre os salários foi desenvolvido por Blinder (1973) ${ }^{17}$ e Oaxaca $(1973)^{18}$. Essencialmente, o modelo assume que na ausência da discriminação os efeitos estimados das características individuais dos trabalhadores sobre os rendimentos são idênticos para cada grupo. Discriminação é revelada por diferenças nos coeficientes estimados. Diferenças não são limitadas ao termo de intercepto através da simples especificações de variáveis binárias, mas também inclui variações na inclinação dos coeficientes" (Berndt, 1990, p. 182).

Para medir discriminação e segmentação, a amostra será dividida em 2 grupos, um grupo considerado como estando em situação de vantagem em relação ao outro grupo, indicado com o asterisco sobrescrito, e um grupo em situação de desvantagem, indicado com o asterisco subscrito. Escreve-se as equações da seguinte forma:

$\ln y^{*}=\alpha^{*}+X^{*} \beta^{*}+\varepsilon^{*}$ para o grupo em vantagem (homem, setor formal e brancos)

$\ln \mathrm{y}_{*}=\alpha_{*}+\mathrm{X}_{*} \beta_{*}+\varepsilon_{*}$ para o grupo em desvantagem (mulher e setor informal e não brancos)

onde:

$\mathrm{y}=$ vetor de rendimentos,

${ }^{17}$ BLINDER, A. S. Wage discrimination: reduced form and structural estimates. Journal of Human Resources. vol. $18, n^{\circ} 4$, fall, 436-455.

${ }^{18}$ OAXACA, R. Male female wage differentials in urban labor markets. International Economic Review, vol. 14, $\mathrm{n}^{\circ}$ 3, October, 693-709. 
$\alpha=$ intercepto,

$\mathrm{X}=$ matriz das variáveis explanatórias,

$\beta=$ coeficiente de regressão,

$\varepsilon=$ erro aleatório.

As estimativas de $\beta^{*}$ e $\beta_{*}$ são respectivamente $\mathrm{b}^{*}$ e $\mathrm{b}_{*} \mathrm{e}$, as estimativas de $\alpha^{*}$ e $\alpha$, são respectivamente $\mathrm{a}^{*}$ e $\mathrm{a}_{*}$.

A propriedade fundamental da estimativa por mínimos quadrados é que a linha de regressão ajustada passa através do ponto das médias amostrais. Isto implica que

$\overline{\operatorname{lny}}^{*}=a^{*}+\bar{X}^{*} b^{*}$ e $\quad \overline{\ln }_{*}=a_{*}+\bar{X}_{*} b_{*}$

e que a diferença na média no logaritmo neperiano dos rendimentos previstos para os dois grupos é

$\overline{\ln y}^{*}-\overline{\ln }_{*}=a^{*}+\bar{X}^{*} b^{*}-\left(a_{*}+\bar{X}_{*} b_{*}\right)$

A diferença entre os vetores de coeficientes do grupo em vantagem e do grupo em desvantagem é

$\Delta b=b^{*}-b_{*}$ implicando que $b^{*}=b_{*}-\Delta b$

Substituindo a segunda equação de (16) na equação (15) e rearranjando os termos temos o seguinte resultado:

$\overline{\operatorname{lny}}^{*}-\overline{\operatorname{lny}}_{*}=\left(a^{*}-a_{*}\right)+b_{*}\left(\bar{X}^{*}-\bar{X}_{*}\right)+\overline{\mathrm{X}}^{*}\left(b^{*}-b_{*}\right)$

(DR)

( I)

$(\mathrm{CP})$

(C) 
A equação (17) é muito importante, pois, como foi enfatizada por Blinder e Oaxaca, pois ela mostra que a diferença no logaritmo neperiano dos rendimentos (DR) entre os grupos em vantagem e desvantagem pode ser decomposta em dois efeitos diferentes: $\mathrm{CP}$ e $\mathrm{D}$ (onde $\mathrm{D}=\mathrm{C}+\mathrm{I}$ ). $\mathrm{O}$ termo $\mathrm{CP}$ da equação (17) refere-se à diferença nos rendimentos devido a diferenças na média das características produtivas entre os grupos. $\mathrm{O}$ termo $\mathrm{C}$ é a porção atribuída a diferenças nos coeficientes estimados para os dois grupos e I é a porção não explicada dos interceptos dos dois grupos. O efeito da discriminação (D) é então revelado pela diferença nos coeficientes estimados (C) mais a porção não explicada dos interceptos (I).

Note que a diferença das médias das características produtivas na equação (17) é ponderada pelo coeficiente estimado para os trabalhadores em situação de desvantagem, enquanto a diferença nos coeficientes estimados é ponderada pelas características produtivas médias dos trabalhadores em vantagem.

Um procedimento alternativo envolve resolver o primeiro termo da equação (17) por $b_{*}$ ao invés de $b^{*}$, ou seja, $b_{*}=b^{*}-\Delta b$. Substituindo esta equação na equação (15) e rearranjando os termos produz o seguinte resultado:

$$
\overline{\operatorname{lny}}^{*}-\overline{\operatorname{lny}}_{*}=\left(\mathrm{a}^{*}-\mathrm{a}_{*}\right)+\mathrm{b}^{*}\left(\overline{\mathrm{X}}^{*}-\overline{\mathrm{X}}_{*}\right)+\overline{\mathrm{X}}_{*}\left(\mathrm{~b}^{*}-\mathrm{b}_{*}\right)
$$
(DR)
( I )
( CP )
(C)

onde a diferença das médias das características produtivas na equação (18) é ponderada pelo coeficiente estimado para os trabalhadores em situação de vantagem, enquanto a diferença nos coeficientes estimados é ponderada pelas características produtivas médias dos trabalhadores em desvantagem.

A escolha entre o uso da equação (17) ou da equação (18) para medir a discriminação é essencialmente um problema clássico de números índices, envolvendo a decisão de qual ponderação empregar. Na prática, os pesquisadores 
empíricos têm utilizado ambas equações, argumentando que juntas elas sustentam os efeitos estimados da discriminação sobre os rendimentos.

\subsubsection{Rendimentos potenciais dos grupos em desvantagem}

Para estimar o diferencial nos rendimentos dos grupos em vantagem em relação ao grupo em desvantagem calcula-se o rendimento hipotético do grupo em situação de desvantagem usando suas próprias características produtivas (médias) e a estrutura do grupo em vantagem (coeficientes estimados para o grupo em situação de vantagem).

A equação a seguir sistematiza esta idéia:

$\overline{\ln Z}_{*}=\mathrm{a}^{*}+\overline{\mathrm{X}}_{*} \mathrm{~b}^{*}$

onde;

$\overline{\ln Z_{*}}=$ rendimento médio hipotético do grupo em desvantagem,

$\overline{\mathrm{X}}_{*}=$ média das características produtivas do grupo em desvantagem;

$\mathrm{b}^{*}=$ coeficientes de regressão dos grupos em vantagem,

$\mathrm{a}^{*}=$ intercepto da regressão estimada para os grupos em vantagem.

Após calcular o rendimento hipotético para o grupo em desvantagem $\left(\overline{\ln Z_{*}}\right)$, o diferencial de rendimentos que permanecer entre os dois grupos $\left(\overline{\ln y^{*}}-\overline{\ln Z_{*}}\right)$, será atribuído somente a diferenças nas características produtivas. Esta porção é freqüentemente descrita como "explicada". O aumento nos rendimentos dos grupos em desvantagem reflete a porção "inexplicada" ou "injustificada" dos diferenciais de rendimentos, ou seja, é a porção atribuída à discriminação. 
Este procedimento foi utilizado por Brown, Moon e Zoloth (1980). Este estudo teve como base o modelo econométrico desenvolvido por Blinder (1973) e Oaxaca (1973) para medir o efeito da discriminação sobre os salários, o qual foi descrito anteriormente. Este procedimento será utilizado para verificar a existência de discriminação entre homens e mulheres nos diversos mercados de trabalho e para detectar segmentação entre estes mercados.

\subsection{Operacionalização dos mercados de trabalho formal e informal neste estudo}

Os setores formal/informal possuem difícil caracterização, haja vista as diversas concepções alternativas associadas às suas definições, como foi visto no capítulo 02. Eles podem ser caracterizados pela natureza e estrutura do processo produtivo (enfoque adotado pela OIT e pelo PREALC), pelo caráter legal das atividades econômicas (enfoque da economia subterrânea), pela questão da inserção do trabalhador no mercado de trabalho vis-a-vis o mercado de produto (abordagem subordinada e intersticial) ou pelo caráter legal dos contratos de trabalho (acesso à carteira de trabalho).

Frequentemente na literatura brasileira, para dimensionar o mercado de trabalho informal, é utilizado o artifício "empregados com ou sem carteira". Assim, devido a natureza dos dados a serem utilizados neste estudo, adotou-se a visão que destaca o acesso à carteira de trabalho como linha divisória entre o mercado de trabalho formal e o mercado de trabalho informal. Os empregados com carteira de trabalho assinada e os funcionários públicos são identificados como trabalhadores formais, enquanto aqueles sem carteira de trabalho assinada e os trabalhadores por conta própria compõem a categoria de trabalhadores informais. Analisa-se a categoria denominada empregadores em separado devido a suas características serem bastante particulares e diferenciarem dos demais trabalhadores. 


\section{DADOS}

\subsection{A pesquisa}

As estimativas sobre o setor informal no Brasil em geral apoiamse nos levantamentos realizados pela Fundação IBGE por meio dos Censos Demográficos, Pesquisa Mensal do Emprego (PME) e das Pesquisas Nacionais por Amostra de Domicílios (PNADs). Estas últimas, para tentar captar as relações de trabalho, apresentam informações sobre uma categoria denominada "posição na ocupação da População Economicamente Ativa (PEA) ocupada".

Na realização deste estudo são utilizados dados desagregados da PNAD de 1995, empreendida pelo IBGE. Os dados a serem utilizadas são muito ricos, por tratarem-se de informações individuais, denominados microdados. Os dados que compõem esta pesquisa são obtidos de uma amostra de milhares de indivíduos, onde se têm detalhes da vida sócio-econômica de cada indivíduo, tais como rendimento do trabalho, renda não salarial, região onde vive, raça, nível de escolaridade, idade, número e idade das crianças por família, posição do indivíduo na família, atividade que o indivíduo exerce, número de horas trabalhadas, etc.

Os dados foram coletados em setembro de 1995. Aproximadamente 334.000 indivíduos foram entrevistados em 102.787 unidades domiciliares. 


\subsection{Universo de análise}

Para conduzir este estudo restringiu-se o universo de análise a homens e mulheres na faixa etária entre 25 e 65 anos. Esta faixa de idade foi escolhida como forma de evitar grandes discrepâncias, pois trabalhadores muito jovens recebem salários muito baixos e pessoas de idade elevada, em sua grande maioria, são aposentadas ou recebem baixos salários. Foram eliminados também trabalhadores da zona rural, pois os dois mercados de trabalho (urbano e rural) são extremamente heterogêneos. Foram excluídas da amostra as categorias de trabalhadores denominados "trabalhadores na construção para o próprio uso", "trabalhadores na produção para o próprio consumo" e "trabalhadores não remunerados", estes, por não possírem rendimentos, seriam automaticamente eliminados nas equações de rendimentos. Após estas exclusões a amostra reduziu-se a 113.643 indivíduos.

A composição da população amostrada em 1995 era composta de $31,84 \%$ indivíduos que não trabalhavam, $33,68 \%$ de indivíduos que eram empregados no mercado de trabalho formal, $30,44 \%$ indivíduos que eram empregados no mercado de trabalho informal e $4,04 \%$ que eram empregadores. Os trabalhadores no mercado de trabalho formal estão divididos em: empregados com carteira de trabalho assinada, militares, funcionário público estatuário e empregado doméstico com carteira de trabalho assinada. Os trabalhadores no mercado de trabalho informal são divididos em: empregados sem carteira de trabalho assinada, trabalhadores por conta própria e trabalhadores domésticos sem carteira de trabalho assinada. A Tabela 3 apresenta a proporção de cada categoria de trabalhador na força de trabalho brasileira em 1995. 
Tabela 3. Composição da força de trabalho brasileira por categoria em 1995, para trabalhadores com idade entre 25 e 65 anos residentes no setor urbano.

\begin{tabular}{lc}
\hline categoria $^{1}$ & proporção (\%) \\
\hline empregado c/ carteira assinada & 36,7 \\
militar & 0,4 \\
funcionário público estatuário & 10,4 \\
doméstico c/ carteira assinada & 1,9 \\
empregado s/ carteira assinada & 12,5 \\
doméstico s/ carteira assinada & 6,0 \\
trabalhadores por conta própria & 26,2 \\
empregadores & 5,9 \\
Total & 100 \\
\hline
\end{tabular}

Fonte: PNAD/IBGE, 1995 (Microdados).

1 são apresentadas na Tabela apenas as categorias utilizadas na amostra deste estudo.

A amostra usada neste estudo é composta por 55.265 homens e 58.378 mulheres, a qual inclui indivíduos que não participam do mercado de trabalho, que trabalham no mercado formal, que trabalham no mercado informal e indivíduos que são empregadores. Da amostra selecionada 35.750 indivíduos não trabalham, 38.362 trabalham no mercado formal, 35.027 trabalham no mercado informal e 4.504 são empregadores. Há aproximadamente $10 \%$ mais trabalhadores no mercado de trabalho formal que no mercado de trabalho informal. Deve-se atentar para o fato de este resultado variar conforme o tipo de amostra selecionada, pois sabe-se que na zona rural (cuja população foi excluída da amostra selecionada) predomina o trabalho informal, e também sabe-se que trabalhadores muito jovens e trabalhadores de idade elevada concentram-se mais no mercado de trabalho informal. 


\subsection{Descrição das variáveis}

\subsubsection{Variáveis dependentes}

Equações de participação no mercado de trabalho: a variável dependente que representa este problema não é observada de forma contínua. Ela representa respostas múltiplas dos indivíduos, assumindo valores discretos. Assim, nestas equações a variável dependente assume o valor 0 se o indivíduo não participa do mercado de trabalho, 1 se o indivíduo trabalha no mercado formal, 2 se o indivíduo trabalha no mercado informal e 3 se o indivíduo é empregador

Equações de rendimentos: a partir de informações do rendimento mensal do trabalho principal (em reais) recebido pelo indivíduo participando do mercado de trabalho, (valor este referente a uma semana antes da entrevista), o qual inclui pagamento em mercadorias; e do número de horas trabalhadas por semana construiu-se a variável dependente taxa de salário por hora trabalhada. A variável horas trabalhadas por semana foi multiplicada por 4 para se obter o número de horas trabalhadas por mês. O rendimento mensal do trabalho principal foi dividido pelo número de horas trabalhadas por mês para se construir a variável taxa de salário/hora trabalhada.

\subsubsection{Variáveis exógenas}

As características individuais incluídas são: experiência e escolaridade (variáveis essas representando o capital humano), gênero e raça. A variável experiência foi construída a partir da idade do indivíduo e da idade em que começou a trabalhar, ou seja:

$\exp _{i}=$ idade $_{i}$ - idade em que o individuo $i$ começou a trabalhar 
onde o índice $i$ refere-se a cada indivíduo.

Acredita-se que a experiência tem um efeito positivo e importante na produtividade e portanto na participação do mercado de trabalho e nos rendimentos, pois, o aumento da experiência, aumenta o estoque de capital humano, o que deve aumentar o nível salarial. O aumento salarial, tudo mais constante, deverá aumentar a participação dos indivíduos no mercado de trabalho. A variável experiência ao quadrado será incluída para captar uma possível relação não linear (parabólica) entre experiência e participação no mercado de trabalho e, entre experiência e rendimentos. Isto é, à medida que o indivíduo ganha experiência, é esperado que sua participação no mercado de trabalho e seu rendimento aumente, até atingir um ponto onde o capital humano comece a se depreciar, a partir deste ponto a probabilidade de participação e o nível de rendimento começa a declinar, refletindo o fato de que a partir de uma determinada idade a produtividade dos indivíduos começa a declinar.

$\mathrm{Na}$ coleta de dados o IBGE considera como sendo anos de estudo apenas aqueles em que o indivíduo frequentou escola e obteve aprovação em todas as disciplinas cursadas. A teoria do capital humano afirma que a escolaridade afeta positivamente a produtividade dos trabalhadores, afetando, portanto, a participação dos indivíduos no mercado de trabalho e seus rendimentos, pois, o aumento dos anos de estudo, aumenta o estoque de capital humano, o que deve aumentar o nível salarial, o que deverá aumentar a participação dos indivíduos no mercado de trabalho.

Foram construídas variáveis binárias para as regiões brasileiras (Sudeste, Sul, Centro-Oeste, Norte e Nordeste). Estas variáveis foram incluídas para refletir as diferenças de oportunidade de emprego e de rendimentos entre as regiões.

Construiu-se também variáveis binárias para os grupos de cor existentes no Brasil, onde os indivíduos de cor branca e amarela foram agrupados, principalmente devido ao fato do grupo de indivíduos de cor amarela ser pouco representativo numericamente (representando apenas $0,3 \%$ da amostra total), e também 
devido ao fato de suas características produtivas serem bastante similares. Estas variáveis foram incluídas para considerar a possibilidade de discriminação entre as raças.

A filiação do trabalhador a um sindicato será representada por uma variável binária. Acredita-se que os trabalhadores sindicalizados estão mais protegidos, e portanto, recebem salários mais altos que os trabalhadores não sindicalizados.

O número de filhos, por família , desagregado em 5 diferentes grupos (filhos de 0 a 2 anos, filhos de 3 a 5 anos, filhos de 6 a 12 anos, filhos com mais de 12 anos do sexo masculino e filhos com mais de 12 anos do sexo feminino) será incluído na equação de participação no mercado de trabalho para refletir os custos monetários de cuidar dos filhos, e, portanto, sua interferência na participação dos pais no mercado de trabalho. Espera-se que, quanto maior o número de filhos pequenos em uma família maiores serão os custos incorridos com os seus cuidados, o que deverá diminuir a participação da mãe no mercado de trabalho. Este fato está relacionado com o salário reserva, o qual é o montante de ganho adicional requerido pelo indivíduo (que não está trabalhando), para diminuir em uma unidade seu tempo de laser. Portanto, provalvelmente o salário reserva da mulher com filhos pequenos é maior, e portanto, sua participação no mercado de trabalho é menor que das mulheres sem filhos pequenos.

O total de filhos é desagregado nesses grupos porque a presença de alguns desses grupos podem refletir negativamente na participação do mercado de trabalho, especialmente para as mulheres que tenham filhos com idade inferior a 6 anos, enquanto outros grupos podem aumentar a participação das mulheres no mercado de trabalho. Estas variáveis foram construídas a partir dos dados originais da PNAD de 1995. Entretanto, devido a forma como os dados são apresentados na pesquisa, não foi possível identificar os filhos de todos os indivíduos da amostra selecionada. Foi possível obter o número de filhos apenas para os indivíduos classificados como chefe da família e para seu cônjuge. Em uma família, além do chefe, cônjuge e seus filhos, existem 
indivíduos denominados "outro parente", "agregado", "pensionista", "empregado doméstico" e "parente de empregado doméstico". Não foi possível computar o número de filhos para esses indivíduos e nem mesmo para aqueles que na categoria "posição na família" são filhos. Estes filhos, quando são pais solteiros e continuam a morar na casa dos pais, têm seus filhos classificados pela PNAD como "outro parente". Acredita-se que esta limitação não afete os resultados de forma significativa, pois no total da amostra, os indivíduos que são chefe, cônjuge e filho somam 93,8\%. Além disso, excluindo o chefe e seu cônjuge são poucos os outros componentes da família que possuem filhos.

Todo o tipo de renda não salarial será incluída na equação de participação no mercado de trabalho, tais como: pensão, aposentadoria, aluguel, doações, rendimento de aplicações, etc. Postula-se que essa variável tem um efeito negativo na participação no mercado de trabalho.

Serão incluídas variáveis binárias para a posição do indivíduo na família, pois acredita-se que o chefe tenha uma maior participação no mercado de trabalho que os demais membros da família.

Na equação de participação no mercado de trabalho será incluída uma variável binária representando o estado conjugal dos indivíduos. Espera-se que esta variável tenha efeito positivo sobre a participação dos homens, pois é uma característica da sociedade brasileira que a responsabilidade, quanto às despesas da família, seja do homem. Para a mulher espera-se o efeito contrário, pois, apesar de nos últimos anos a participação da mulher brasileira no mercado de trabalho, tanto a casada como a solteira, estar aumentando, ainda é uma característica das mulheres casadas serem dependentes financeiramente de seus maridos. Postula-se que quanto mais alto é o salário do marido, menor é a participação da mulher no mercado de trabalho.

A variável binária para a posse ou não de casa própria será incluída como proxy da riqueza, acredita-se que esta variável tenha um efeito negativo na participação no mercado de trabalho. Na equação de rendimentos serão incluídas 
variáveis binárias para os setores de atividades produtivas, setor primário, setor secundário e setor terciário. Espera-se que nos setores secundário e terciário os salários sejam mais altos que no setor primário.

A média, desvios padrões e a descrição das variáveis para 55.265 homens e 58.378 mulheres utilizadas para estimar as equações de participação são apresentadas na Tabela 4 e, a média, desvios padrões e a descrição das variáveis para 23.459 homens no setor formal, 20.658 homens no setor informal, 3.584 homens empregadores, 14.903 mulheres no setor formal, 14.369 mulheres no setor informal e 920 mulheres empregadoras utilizadas para estimar as equações de rendimento são apresentadas na Tabela 5 
Tabela 4. Descrição das variáveis utilizadas nas equações de participação, médias e desvios padrões, para homens e mulheres nos setores formal e informal e para empregadores.

\begin{tabular}{|c|c|c|c|c|c|}
\hline \multirow[b]{2}{*}{ Variáveis } & \multirow[b]{2}{*}{ Descrição das variáveis } & \multicolumn{2}{|c|}{ Homem } & \multicolumn{2}{|c|}{ Mulher } \\
\hline & & média & d.p. & média & $\overline{\text { d.p. }}$ \\
\hline FILHO0-2 & $n^{\circ}$ de filhos de 0 a 2 anos & 0,205 & 0,50 & 0,155 & 0,42 \\
\hline FILHO3-5 & $n^{\circ}$ de filhos de 3 a 5 anos & 0,237 & 0,51 & 0,201 & 0,47 \\
\hline FILHO6-12 & $\mathrm{n}^{\circ}$ de filhos de 6 a 12 anos & 0,632 & 0,98 & 0,610 & 0,93 \\
\hline FILHA $>12$ & $\mathrm{n}^{\circ}$ de filhas maiores de 12 anos & 0,365 & 0,74 & 0,396 & 0,75 \\
\hline FILHO $>12$ & $\mathbf{n}^{\circ}$ de filhos maiores de 12 anos & 0,447 & 0,85 & 0,487 & 0,86 \\
\hline CHEFE & $=1$ se o indivíduo é chefe & 0,847 & 0,36 & 0,222 & 0,420 \\
\hline & & & & & , \\
\hline FILHO & $=1$ se 0 indivíduo é filho & 0,113 & 0,32 & 0,0829 & 0,27 \\
\hline CÔNJUGE & $=1$ se o indivíduo é cônjuge & - & - & 0,650 & 0,48 \\
\hline ESTADO CONJ. & $=1$ se o indivíduo é casado & 0,795 & 0,41 & 0,661 & 0,47 \\
\hline EXPERIÊNCIA & anos de experiência do indivíduo & 24,18 & 13,18 & 13,20 & 14,35 \\
\hline EXPERIÊNCIA2 & anos de experiência do indiv. ao quadrado & 760,6 & 685,5 & 380,30 & 570,1 \\
\hline ESCOLARIDADE & $\mathrm{n}^{\circ}$ de anos que o indiv. freqüentou escola ${ }^{1}$ & 6,27 & 4,45 & 6,17 & 4,49 \\
\hline EDUCEXP & interação das var. escolaridade e experiên. & 139,9 & 132,2 & 82,48 & 121,7 \\
\hline R. BRANCA & $=1$ se o indivíduo é branco & 0,600 & 0,49 & 0,608 & 0,50 \\
\hline R. PARDA & $=1$ se o indivíduo é pardo & 0,345 & 0,49 & 0,337 & 0,48 \\
\hline CASA PRÓPRIA & $=1$ se o indivíduo possui casa própria & 0,742 & 0,43 & 0,757 & 0,42 \\
\hline RENDA NÃO SAL. & valor de rendimentos não salariais & 71,10 & 384,1 & 50,75 & 241,0 \\
\hline R. NORTE & $=1$ se $o$ indivíduo reside na Região Norte & 0,0489 & 0,27 & 0,0464 & 0,26 \\
\hline R. SUL & $=1$ se o indivíduo reside na Região Sul & 0,157 & 0,38 & 0,154 & 0,38 \\
\hline R. SUDESTE & $=1$ se $o$ indivíduo reside na Região Sudeste & 0,522 & 0,49 & 0,518 & 0,49 \\
\hline R. CENTRO-OESTE & $=1$ se $o$ indivíduo reside na Região C. Oeste & 0,0696 & 0,31 & 0,0665 & 0,30 \\
\hline
\end{tabular}

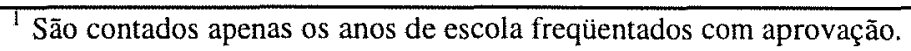


Tabela 5. Descrição das variáveis utilizadas nas equações de rendimentos, médias e desvios padrões, para homens e mulheres nos setores formal e informal e para empregadores.

\begin{tabular}{|c|c|c|c|c|c|c|c|c|c|c|c|c|c|}
\hline \multirow{3}{*}{ Variáveis } & \multirow{3}{*}{ Descrição das variáveis } & \multicolumn{6}{|c|}{ Homem } & \multicolumn{6}{|c|}{ Mulher } \\
\hline & & \multicolumn{2}{|c|}{ Formal } & \multicolumn{2}{|c|}{ Informal } & \multicolumn{2}{|c|}{ Empregadores } & \multicolumn{2}{|c|}{ Formal } & \multicolumn{2}{|c|}{ Informal } & \multicolumn{2}{|c|}{ Empregadores } \\
\hline & & média & d.p. & média & d.p. & média & d.p & média & d.p. & media & d.p. & média & d.p. \\
\hline SALÁRIO & taxa do salário hora & 3,95 & 6,07 & 2,83 & 5,02 & 9,39 & 16,75 & 2,94 & 4,16 & 2,01 & 3,38 & 7,93 & 9,79 \\
\hline LN SALÁRIO & logaritmo da taxa de salário hora & 0,89 & 0,90 & 0,50 & 0,98 & 1,70 & 1,00 & 0,64 & 0,88 & 0,16 & 0,89 & 1,60 & 1,00 \\
\hline LAMBDA & inverso da razão de Mill & 0,81 & - & 0,90 & - & 1,75 & - & 0,83 & - & 0,89 & - & 2,11 & - \\
\hline ESCOLARIDADE & $n^{\circ}$ de anos que o ind. freqüentou escola ${ }^{1}$ & 7,25 & 4,39 & 5,12 & 4,10 & 8,91 & 4,49 & 8,89 & 4,49 & 5,43 & 4,10 & 10,59 & 4,03 \\
\hline EXPERIÊNCIA & anos de experiência do indivíduo & 24,64 & 10,73 & 28,14 & 11,79 & 28,98 & 11,22 & 21,44 & 10,31 & 25,24 & 12,05 & 23,53 & 10,77 \\
\hline EXPERIÊNCIA2 & anos de experiência do indiv. ao quadrado & 722,7 & 600,2 & 931,1 & 723,9 & 966,7 & 682,6 & 566,0 & 508,3 & 780,5 & 671,8 & 671,0 & 563,9 \\
\hline EDUCEXP & interação das var. escolaridade e experiên. & 163,5 & 124,8 & 129,5 & 120,7 & 240,2 & 149,2 & 174,4 & 122,8 & 117,8 & 104,5 & 231,0 & 132,1 \\
\hline R. BRANCA & =1 se o indivíduo é branco & 0,62 & 0,49 & 0,54 & 0,50 & 0,78 & 0,44 & 0,64 & 0,49 & 0,55 & 0,50 & 0,83 & 0,39 \\
\hline R PARDA & $=1$ se o indivíduo é pardo & 0,32 & 0,48 & 0,40 & 0,50 & 0,21 & 0,43 & 0,30 & 0,47 & 0,38 & 0,49 & 0,16 & 0,39 \\
\hline R. NORTE & $=1$ se o indivíduo reside na $R$. Norte & 0,037 & 0,23 & 0,067 & 0,30 & 0,046 & 0,25 & 0,043 & 0,25 & 0,052 & 0,27 & 0,034 & 0,23 \\
\hline R. SUL & $=1$ se $o$ indivíduo reside na $R$. Sul & 0,17 & 0,49 & 0,15 & 0,47 & 0,20 & 0,49 & 0,18 & 0,49 & 0,15 & 0,47 & 0,25 & 0,48 \\
\hline R. SUDESTE & $=1$ se $o$ indivíduo reside na $R$. Sudeste & 0,58 & 0,39 & 0,45 & 0,37 & 0,52 & 0,42 & 0,54 & 0,40 & 0,48 & 0,37 & 0,50 & 0,45 \\
\hline R. C. OESTE & $=1$ se o indivíduo reside na R.C. Oeste & 0,061 & 0,30 & 0,081 & 0,32 & 0,085 & 0,33 & 0,065 & 0,30 & 0,070 & 0,30 & 0,055 & 0,28 \\
\hline S. SECUNDÁRIO & $=1$ se $o$ ind. trabalha no $S$. secundário & 0,38 & 0,48 & 0,28 & 0,45 & 0,27 & 0,44 & 0,15 & 0,35 & 0,061 & 0,24 & 0,18 & 0,38 \\
\hline S. TERCIÁRIO & $=1$ se $o$ indivíduo trabalha no $S$. terciário & 0,59 & 0,49 & 0,58 & 0,49 & 0,62 & 0,48 & 0,84 & 0,36 & 0,91 & 0,31 & 0,80 & 0,40 \\
\hline SINDICATO & =1 se o indivíduo é trabalhador sindicaliz. & 0,36 & 0,48 & 0,090 & 0,28 & 0,20 & 0,40 & 0,30 & 0,47 & 0,040 & 0,20 & 0,20 & 0,41 \\
\hline
\end{tabular}




\section{DESCRIÇÃO E ANÁLISE DA AMOSTRA}

A Tabela 6 mostra a participação da força de trabalho brasileira por mercados de trabalho (formal e informal) e empregadores por faixa etária (25-34, 3544, 45-54 e mais de 55 anos de idade), por anos de estudo ( 0 a 3,4 a 7,8 a 10, $2^{2}$ grau completo, superior completo e mestrado/doutorado), por Região (Nordeste, Norte, Centro-Oeste, Sul e Sudeste), por cor (branca/amarela, parda e preta), por gênero e por setor de atividade econômica (setor primário, setor secundário e setor terciário), bem como a proporção da população amostrada que não participa da força de trabalho por cada categoria citada (idade, estudo, região, raça, gênero e setor).

A Tabela 6 possibilita análises muito interessantes. Os trabalhadores na faixa etária entre 25 e 44 anos concentram-se mais no mercado de trabalho formal, enquanto que aqueles com idade variando de 45 a 65 concentram-se mais no mercado de trabalho informal, indicando que trabalhadores mais velhos encontram mais oportunidade de emprego no mercado de trabalho informal.

Escolaridade afeta positivamente a participação no mercado de trabalho. Com o aumento da escolaridade decresce a probabilidade do indivíduo não participar do mercado de trabalho. Do total de trabalhadores com até 3 anos de estudo $41,49 \%$ não participam da força de trabalho enquanto que dos indivíduos com mestrado ou doutorado apenas $7,77 \%$ não estão no mercado de trabalho. A probabilidade do indivíduo participar do mercado de trabalho formal aumenta a cada nível de escolaridade, o mesmo comportamento é observado para os empregadores. O oposto é observado no mercado de trabalho informal, o aumento da escolaridade diminui a possibilidade do indivíduo participar deste mercado. 
Tabela 6. Participação da força de trabalho por mercados de trabalho (formal e informal) e empregadores e por categorias (faixa etária, anos de estudo, região, raça, gênero, e setor de atividade econômica), para população brasileira em 1995, com idade entre 25 e 65 anos, residentes no setor urbano.

\begin{tabular}{|c|c|c|c|c|}
\hline & não trabalham & formal & informal & empregadores \\
\hline 25 a 34 anos & 27,38 & 39,10 & 30,50 & 3,02 \\
\hline 35 a 44 anos & 24,34 & 38,81 & 32,06 & 4,80 \\
\hline 45 a 54 anos & 33,15 & 29,65 & 32,02 & 5,18 \\
\hline$>54$ anos & 57,35 & 14,47 & 24,65 & 3,52 \\
\hline 0 - 3 anos de estudo & 41,49 & 20,38 & 36,71 & 1,42 \\
\hline 4 - 7 anos de estudo & 33,21 & 30,43 & 33,23 & 3,13 \\
\hline $8-10$ anos de estudo & 29,65 & 37,91 & 28,03 & 4,30 \\
\hline $2^{\circ}$ grau completo & 23,26 & 48,47 & 21,46 & 6,82 \\
\hline Superior (completo) & 13,47 & 57,55 & 17,61 & 11,37 \\
\hline Mestrado/Doutorado & 7,77 & 65,28 & 17,62 & 9,33 \\
\hline sudeste & 32,91 & 36,26 & 26,83 & 4,00 \\
\hline sul & 28,44 & 37,03 & 28,97 & 5,56 \\
\hline centro-oeste & 29,98 & 31,10 & 34,21 & 4,71 \\
\hline norte & 29,49 & 27,92 & 38,87 & 3,71 \\
\hline nordeste & 32,85 & 26,92 & 37,34 & 2,89 \\
\hline Brasil & 31,84 & 33,68 & 30,44 & 4,04 \\
\hline branca/amarela & 31,88 & 35,20 & 27,64 & 5,28 \\
\hline parda & 31,67 & 30,77 & 35,22 & 2,35 \\
\hline preta & 32,47 & 35,03 & 31,57 & 0,93 \\
\hline homem & 13,74 & 42,67 & 36,99 & 6,60 \\
\hline mulher & 49,06 & 25,13 & 24,20 & 1,61 \\
\hline primário & - & 18,75 & 71,46 & 9,79 \\
\hline secundário & - & 59,31 & 34,66 & 6,02 \\
\hline terciário & - & 48,60 & 45,83 & 5,56 \\
\hline
\end{tabular}

Fonte: PNAD/1BGE, 1995 (Microdados). 
Nas regiões brasileiras mais desenvolvidas (sudeste e sul) predomina o trabalho formal, enquanto que nas outras regiões predomina o trabalho informal. Pode-se observar também que um indivíduo possui maior oportunidade de ser empregador nas regiões mais desenvolvidas que nas demais. Enquanto na Região Sul 5,56 do total de trabalhadores são empregadores, na Região Nordeste este percentual é de apenas 2,89

No que refere-se à participação dos grupos étnicos no mercado de trabalho observamos uma relação não esperada, ou seja, existe uma maior proporção de negros no mercado de trabalho formal que no mercado de trabalho informal. Já na categoria empregadores, apenas 0,93 dos indivíduos negros são empregadores contra 5,28 dos indivíduos brancos. Os indivíduos da raça branca/amarela estão mais concentrados no mercado de trabalho formal da economia, enquanto os indivíduos da raça parda encontram-se em maior proporção no mercado de trabalho informal.

Como é de se esperar, a participação da mulher brasileira no mercado de trabalho está muito abaixo da participação do homem. A proporção de mulheres empregadas no mercado de trabalho informal $(47,6 \%$ das mulheres que participam da força de trabalho) é maior que a proporção de homens empregados no mesmo mercado $(43,3 \%$ dos homens que participam da força de trabalho são trabalhadores informais), indicando que as mulheres que participam da força de trabalho encontram mais oportunidade de emprego no mercado de trabalho informal do que os homens.

As relações de trabalho são relativamente mais informais no setor primário e terciário da economia. Três quartos dos trabalhadores no setor primário são informais e no setor terciário quase a metade dos trabalhadores são informais. No setor secundário os trabalhadores são predominantemente formais, quase $60 \%$ dos trabalhadores neste setor estão no mercado de trabalho formal e apenas $35 \%$ estão no mercado informal. 
Embora a participação feminina no mercado de trabalho esteja aumentando verificamos que as mulheres ainda recebem salários mais baixos que os homens. Isto pode ser visto na Tabela 7, onde são apresentados os salários médios (por hora trabalhada) para homens e mulheres nos mercados de trabalho formal e informal e para empregadores.

Tabela 7. Rendimentos médios (por hora trabalhada) setoriais por grupos de sexo no Brasil em 1995 (para população ocupada com idade entre 25 e 65 anos residentes no setor urbano), valores expressos em Reais.

\begin{tabular}{lccc}
\hline & homem & mulher & $\operatorname{taxa}^{1}$ \\
\hline setor formal & 3,95 & 2,94 & 0,74 \\
setor informal & 2,83 & 2,01 & 0,71 \\
empregadores & 9,39 & 7,93 & 0,84 \\
\hline
\end{tabular}

Fonte: PNAD/IBGE, 1995 (Microdados).

${ }^{1}$ a taxa é a relação entre o rendimento da mulher e o rendimento do homem, ou seja, é a proporção do rendimento do homem que a mulher recebe.

Como demonstraram os dados da Tabela 7 , os rendimentos são, em média, mais altos no mercado de trabalho formal em relação ao mercado de trabalho informal, os homens no mercado de trabalho informal recebem cerca de $71 \%$ dos rendimentos pagos no mercado de trabalho formal e as mulheres $65 \%$ É importante notar as diferenças nos rendimentos por gênero entre os mercados de trabalho formal e informal e empregadores. As diferenças nos rendimentos são maiores no mercado de trabalho informal (as mulheres recebem cerca de $71 \%$ do rendimento dos homens) que no mercado de trabalho formal (as mulheres recebem cerca de $74 \%$ do rendimento dos homens) e empregadores, em que as mulheres recebem cerca de $84 \%$ dos rendimentos dos homens. Uma explicação plausível para as mulheres trabalhando no setor formal possuírem um diferencial de rendimento menor que das trabalhadoras no setor informal, está na proteção legal dos contratos de trabalho (salário mínimo, férias, décimo terceiro, etc.). 
O Brasil é um país extenso e bastante heterogêneo no que diz respeito às características sócio-econômicas de suas regiões. A Tabela 8 permite observar diferenças entre os rendimentos dos trabalhadores residentes nas regiões altamente industrializadas e modernas e daqueles trabalhadores residentes nas regiões menos desenvolvidas. A Tabela 8 mostra os salários médios (por hora trabalhada) em cada região, separados por gênero.

Tabela 8. Rendimentos médios (por hora trabalhada) regionais por grupos de sexo no Brasil em 1995 (para população ocupada com idade entre 25 e 65 anos residentes no setor urbano), valores expressos em Reais.

\begin{tabular}{lccc}
\hline Região & homem & mulher & taxa \\
\hline Sudeste & 4,47 & 3,01 & 0,67 \\
Sul & 4,11 & 2,69 & 0,65 \\
Centro-Oeste & 3,78 & 2,62 & 0,69 \\
Norte & 3,05 & 2,55 & 0,84 \\
Nordeste & 2,45 & 1,83 & 0,75 \\
Brasil & 3,88 & 2,66 & 0,69 \\
\hline
\end{tabular}

Fonte: PNAD/IBGE, 1995 (Microdados).

A Tabela 8 mostra que os rendimentos médios entre as regiões são bastante diferentes (é importante notar que estes rendimentos não foram ajustados para refletir as diferenças no custo de vida entre as regiões que possam existir). Os rendimentos são notavelmente mais baixos nas regiões nordeste e norte, tanto para o homem quanto para a mulher. A taxa de rendimento mulher/homem é mais alta nessas mesmas regiões, norte e nordeste. Parece existir uma relação entre baixos rendimentos e taxas de rendimento mulher/homem mais elevada, indicando menor diferença entre os rendimentos das mulheres e dos homens. Estes resultados podem ser explicados pelo fato de existir, nas regiões mais pobres, uma maior concentração dos trabalhadores nos extratos de renda mais baixos, de modo que tanto o homem quanto a mulher auferem baixos rendimentos. Nas regiões mais pobres as oportunidades de se alcançar postos de trabalho mais elevados, de modo a elevar o rendimento médio, são mais escassas tanto 
para o homem quanto para a mulher, não existindo assim uma variabilidade muito grande entre os rendimentos do homem e da mulher para a maior parte dos trabalhadores.

A Tabela 9 mostra a relação entre níveis de escolaridade e rendimento médio para homens e mulheres. Os resultados obtidos são os esperados, ou seja, com o aumento no nível de escolaridade o rendimento médio eleva-se para ambos os sexos.

Tabela 9. Rendimentos médios (por hora trabalhada) por níveis de escolaridade e sexo no Brasil em 1995 (para população ocupada com idade entre 25 e 65 anos residentes no setor urbano), valores expressos em Reais.

\begin{tabular}{cccc}
\hline & Homem & Mulher & Taxa \\
\hline 0 - 3 anos de estudo & 1,64 & 1,13 & 0,69 \\
4 - 7 anos de estudo & 2,55 & 1,57 & 0,62 \\
8 - 10 anos de estudo & 3,42 & 2,08 & 0,61 \\
$2^{\circ}$ grau (completo) & 5,48 & 3,26 & 0,59 \\
Superior (completo) & 13,22 & 7,06 & 0,53 \\
Mestrado/Doutorado & 17,42 & 11,10 & 0,64 \\
\hline
\end{tabular}

Fonte: PNAD/IBGE, 1995 (Microdados).

Analisando a Tabela 9 observa-se que o maior incremento nos rendimentos entre os níveis de escolaridade ocorre entre o segundo grau e o curso de nível superior, o incremento é em torno de $140 \%$ para o homem e de $117 \%$ para a mulher.

Um resultado interessante é o fato de que com o aumento do nível de escolaridade ocorre um aumento nos diferenciais de rendimentos entre homem e mulher, exceto para indivíduos com mestrado/doutorado, onde o diferencial cai em 11 pontos percentuais em relação ao diferencial existente entre homens e mulheres com o nível superior. Este último resultado explica-se pelo fato do aumento do rendimento para as mulheres com grau de mestrado/doutorado em relação àquelas com apenas o nível superior ser de $57 \%$ enquanto que este mesmo aumento para os homens é de apenas $32 \%$. 


\section{RESULTADOS DOS MODELOS ECONOMÉTRICOS}

\subsection{Os determinantes da participação da força de trabalho nos mercados de trabalho formal e informal e para empregadores}

A Tabela 10 apresenta os resultados das equações de participação, usando o modelo lógite multinomial, estimado por máxima verossimilhança, para os 03 segmentos de mercado de trabalho, para homens e mulheres residindo no setor urbano com idade entre 25 e 65 anos. Nela estão apresentados os efeitos marginais (em negrito), os coeficientes estimados em seguida, e os testes-t entre parênteses.

O vetor de variáveis exógenas incluídas nesta análise, para estimar a equação de participação no mercado de trabalho são: o número de filhos, variáveis binárias para posição de ocupação na família (CHEFE, CÔNJUGE, FILHO e OUTROS - variável omitida), ESTADO CONJUGAL, EXPERIÊNCIA, experiência ao quadrado (EXPERIENNCIA2), ESCOLARIDADE, uma variável representando a interação entre anos de estudo e experiência (EDUCEXP), variáveis binárias para grupos de cor BRANCA, PARDA e PRETA - variável omitida), CASA PRÓPRIA e RENDA NÃO SALARIAL como proxy da riqueza e, variáveis binárias para a região de residência ( $R$. NORTE, R. SUL, R. SUDESTE, R. CENTRO-OESTE e R. NORDESTE - variável omitida ). 
Tabela 10. Equações de participação da força de trabalho brasileira para homens e mulheres nos mercados de trabalho formal e informal e para empregadores. Efeitos marginais (em negrito), coeficientes e testes-t (em parênteses).

\begin{tabular}{|c|c|c|c|c|c|c|}
\hline \multirow{2}{*}{ Variáveis } & \multicolumn{3}{|c|}{ Homem } & \multicolumn{3}{|c|}{ Mulher } \\
\hline & Formal & Informal Er & Empregadores & Formal & Informal & Empregadores \\
\hline \multirow{3}{*}{ CONSTANTE } & $-0,107$ & 0,175 & $-0,331$ & $-0,534$ & $-0,396$ & $-0,0544$ \\
\hline & $-3,736$ & $-3,077$ & $-10,421$ & $-4,656$ & $-3,351$ & $-11,968$ \\
\hline & $(-27,30)^{* * *}$ & $(-22,55)^{* * *}$ & $(-32,92)^{* * *}$ & $(-34,02)^{* * *}$ & $(-26,80)^{* * *}$ & $(-21,65)^{* * *}$ \\
\hline \multirow{3}{*}{ FILHO0-2 } & $-0,0140$ & 0,0346 & $-0,00496$ & $-0,0257$ & $-0,0112$ & $-0,00134$ \\
\hline & 0,178 & 0,293 & 0,104 & $-0,208$ & $-0,113$ & $-0,319$ \\
\hline & $(3,96)^{* * *}$ & $(6,48)^{* * *}$ & $(1,72)^{*}$ & $(-4,83)^{* * *}$ & $(-2,76)^{* * *}$ & $(-2,96)^{* * *}$ \\
\hline \multirow{3}{*}{ FILHO3-5 } & $-0,00832$ & 0,0232 & 0,00121 & $-0,0187$ & 0,0227 & $-0,00125$ \\
\hline & 0,197 & 0,273 & 0,241 & $-0,0969$ & 0,0968 & $-0,230$ \\
\hline & $(4,48)^{* * *}$ & $(6,15)^{* * *}$ & $(4,26)^{* * *}$ & $(-2,46)^{* *}$ & $(2,62)^{* * *}$ & $(-2,37)^{* *}$ \\
\hline \multirow{3}{*}{ FILHO6-12 } & $-0,0000219$ & $-0,00194$ & $-0,00233$ & $-0,0105$ & 0,00969 & $-0,000340$ \\
\hline & $-0,0604$ & $-0,0647$ & $-0,109$ & $-0,0595$ & 0,0371 & $-0,0660$ \\
\hline & $(-2,66)^{* * *}$ & $(-2,85)^{* * *}$ & $(-3,67)^{* * *}$ & $(-2,78)^{* * *}$ & $(1,84)^{*}$ & $(-1,37)$ \\
\hline \multirow{3}{*}{ FILHA $>12$} & 0,00656 & $-0,0172$ & 0,000297 & $-0,00628$ & $-0,0201$ & 0,0000636 \\
\hline & $-0,124$ & $-0,180$ & $-0,131$ & $-0,0809$ & $-0,128$ & $-0,0348$ \\
\hline & $(-4,30)^{* * *}$ & $(-6,26)^{* * *}$ & $(-3,64)^{* * *}$ & $(-2,89)^{* * *}$ & $(-4,82)^{* * *}$ & $(-0,64)$ \\
\hline \multirow{3}{*}{ FILHO $>12$} & 0,00557 & $-0,0150$ & 0,000511 & $-0,0184$ & $-0,0279$ & $-0,000430$ \\
\hline & $-0,107$ & $-0,156$ & $-0,108$ & $-0,183$ & $-0,196$ & $-0,166$ \\
\hline & $(-4,24)^{* * *}$ & $(-6,19)^{* * *}$ & $(-3,38)^{* * *}$ & $(-7,31)^{* * *}$ & $(-8,32)^{* * *}$ & $(-3,16)^{* * *}$ \\
\hline \multirow{3}{*}{ CHEFE } & $-0,00534$ & $-0,0142$ & 0,0380 & $-0,00784$ & 0,00189 & 0,00260 \\
\hline & 0,235 & 0,211 & 1,039 & $-0,0486$ & 0,00171 & 0,481 \\
\hline & $(2,51)^{* *}$ & $(2,23)^{* *}$ & $(5,84)^{* * *}$ & $(-0,53)$ & $(0,02)$ & $(1,94)^{*}$ \\
\hline \multirow{3}{*}{ FILHO } & $-0,0647$ & 0,0486 & 0,0227 & 0,0245 & 0,0281 & $-0,000608$ \\
\hline & 0,300 & 0,510 & 0,863 & 0,225 & 0,206 & $-0,0219$ \\
\hline & $(3,31)^{* * *}$ & $(5,54)^{* * *}$ & $(4,60)^{* * *}$ & $(2,33)^{* *}$ & $(2,09)^{* *}$ & $(-0,080)$ \\
\hline \multirow{3}{*}{ CÔNJUGE } &. & - & - & $-0,0425$ & $-0,0380$ & 0,000489 \\
\hline & - & - & - & $-0,373$ & $-0,295$ & $-0,0501$ \\
\hline & - & - & - & $(-2,14)^{* *}$ & $(-1,72)^{*}$ & $(-0,14)$ \\
\hline \multirow{3}{*}{ ESTADO CONJ. } & 0,0647 & $-0,0577$ & 0,0111 & $-0,0648$ & $-0,0290$ & 0,00200 \\
\hline & 0,378 & 0,0986 & 0,473 & $-0,515$ & $-0,280$ & 0,213 \\
\hline & $(5,43)^{* * *}$ & $(1,41)$ & $(4,85)^{* * *}$ & $(-3,23)^{* * *}$ & $(-1,79)^{*}$ & $(0,75)$ \\
\hline \multirow{3}{*}{ EXPERIÊNCIA } & 0,00969 & 0,00936 & 0,00510 & 0,0480 & 0,0540 & 0,00159 \\
\hline & 0,342 & 0,345 & 0,428 & 0,445 & 0,401 & 0,482 \\
\hline & $(62,32)^{* * *}$ & $(63,38)^{* * *}$ & $(38,60)^{* * *}$ & $(77,10)^{* * *}$ & $(84,42)^{* * *}$ & $(26,21)^{* * *}$ \\
\hline \multirow{3}{*}{ EXPERIÊNCLA2 } & $-0,000211$ & $-0,0000857$ & $-0,0000435$ & $-0,000766$ & $-0,000780$ & $-0,0000206$ \\
\hline & $-0,00499$ & $-0,00475$ & $-0,00545$ & $-0,00695$ & $-0,00593$ & $-0,00664$ \\
\hline & $(-56,24)^{* * *}$ & $(-54,66)^{* * *}$ & $(-35,71)^{* * *}$ & $(-69,99)^{* * *}$ & $(-70,31)^{* * *}$ & $(-25,28)^{* * *}$ \\
\hline \multirow{3}{*}{ ESCOLARIDADE } & 0,0294 & $-0,0277$ & 0,0107 & 0,0372 & 0,00684 & 0,00200 \\
\hline & 0,229 & 0,0979 & 0,390 & 0,284 & 0,109 & 0,457 \\
\hline & $(29,54)^{* * *}$ & $(12,24)^{* * *}$ & $(27,59)^{* * *}$ & $(38,51)^{* * *}$ & $(16,29)^{* * *}$ & $(19,06)^{* * *}$ \\
\hline
\end{tabular}


Tabela 10. Equações de participação da força de trabalho brasileira para homens e mulheres nos mercados de trabalho formal e informal e para empregadores. Efeitos marginais (em negrito), coeficientes e testes-t (em parênteses).

\begin{tabular}{|c|c|c|c|c|c|c|}
\hline \multirow[b]{2}{*}{ Variáveis } & \multicolumn{3}{|c|}{ Homem } & \multicolumn{3}{|c|}{ Mulher } \\
\hline & Formal & Informal & Empregadores & Formal & Informal & Empregadores \\
\hline \multirow{3}{*}{ EDUCEXP } & $-0,000267$ & 0,000223 & $-0,000137$ & $-0,000274$ & $-0,000295$ & $-0,0000246$ \\
\hline & $-0,00298$ & $-0,00186$ & $-0,00527$ & $-0,00254$ & $-0,00224$ & $-0,00568$ \\
\hline & $(-9,15)^{* * *}$ & $(-5,69)^{* * *}$ & $(-11,06)^{* * *}$ & $(-6,96)^{* * *}$ & $(-6,59)^{* * *}$ & $(-6,57)^{* * *}$ \\
\hline \multirow{3}{*}{ R. BRANCA } & $-0,0826$ & 0,0265 & 0,0571 & $-0,0479$ & 0,00597 & 0,00826 \\
\hline & $-0,161$ & 0,0789 & 1,205 & $-0,320$ & 0,0356 & 1,490 \\
\hline & $(-2,01)^{* *}$ & $(0,97)$ & $(7,40)^{* * *}$ & $(-4,02)^{* * *}$ & $(0,46)$ & $(3,99)^{* * *}$ \\
\hline \multirow{3}{*}{ R. PARDA } & $-0,0604$ & 0,0210 & 0,0339 & $-0,0374$ & 0,00258 & 0,00514 \\
\hline & $-0,201$ & $-0,0208$ & 0,635 & $-0,256$ & $-0,0423$ & 0,912 \\
\hline & $(-2,44)^{* *}$ & $(-0,25)$ & $(3,81)^{* * *}$ & $(-3,13)^{* * *}$ & $(-0,53)$ & $(2,39)^{* *}$ \\
\hline \multirow{3}{*}{ CASA PRÓPRIA } & $-0,0145$ & $-0,0122$ & 0,0131 & 0,00441 & $-0,0169$ & 0,000901 \\
\hline & $-0,212$ & $-0,211$ & 0,0917 & $-0,00343$ & $-0,0890$ & 0,150 \\
\hline & $(-4,75)^{* * *}$ & $(-4,68)^{* * *}$ & $(1,51)$ & $(-0,09)$ & $(-2,26)^{* *}$ & $(1,67)$ \\
\hline \multirow{3}{*}{ RENDA N. SAL. } & $-0,000222$ & 0,000112 & 0,0000238 & $-0,000272$ & $-0,000170$ & $-0,00000180$ \\
\hline & $-0,00162$ & $-0,000869$ & $-0,000650$ & $-0,00227$ & $-0,00148$ & $-0,00113$ \\
\hline & $(-22,32)^{* * *}$ & $(-14,90)^{* * *}$ & $(-12,07)^{* * *}$ & $(-19,97)^{* * *}$ & $(-13,81)^{* * *}$ & $(-8,44)^{* * *}$ \\
\hline \multirow{3}{*}{ R. NORTE } & $-0,0393$ & 0,0293 & 0,0103 & 0,00402 & $-0,0202$ & $-0,000427$ \\
\hline & $-0,0787$ & 0,0769 & 0,219 & $-0,00758$ & $-0,111$ & $-0,110$ \\
\hline & $(-0,81)$ & $(0,82)$ & $(1,71)^{*}$ & $(-0,08)$ & $(-1,29)$ & $(-0,52)$ \\
\hline \multirow{3}{*}{ R. SUL } & 0,114 & $-0,127$ & 0,00264 & 0,0175 & $-0,0995$ & 0,00117 \\
\hline & 0,0930 & $-0,462$ & $-0,0920$ & $-0,0483$ & $-0,546$ & 0,0759 \\
\hline & $(1,36)$ & $(-6,77)^{* * *}$ & $(-1,03)$ & $(-0,77)$ & $(-9,00)^{* * *}$ & $(0,60)$ \\
\hline \multirow{3}{*}{ R. SUDESTE } & 0,137 & $-0,149$ & $-0,00501$ & 0,0107 & $-0,0789$ & $-0,000590$ \\
\hline & 0,0568 & $-0,602$ & $-0,337$ & $-0,0637$ & $-0,441$ & $-0,233$ \\
\hline & $(1,10)$ & $(-11,75)^{* * *}$ & $(-4,69)^{* * *}$ & $(-1,32)$ & $(-9,51)^{* * *}$ & $(-2,11)^{* *}$ \\
\hline \multirow{3}{*}{ R. C. OESTE } & $-0,0217$ & $-0,0464$ & 0,0112 & $-0,0135$ & $-0,0657$ & $-0,00127$ \\
\hline & $-0,134$ & $-0,295$ & 0,0533 & $-0,216$ & $-0,409$ & $-0,382$ \\
\hline & $(-1,59)$ & $(-3,56)^{* * *}$ & $(0,49)$ & $(-2,74)^{* * *}$ & $(5,40)^{* * *}$ & $(-2,13)^{* *}$ \\
\hline $\begin{array}{l}\text { teste da razão de } \\
\text { verossimilhança }\end{array}$ & $27.073,94^{* * *}$ & $27,073,94^{* * *}$ & $27.073,94^{* * *}$ & $58.724,11^{* * *}$ & $58.724,11^{* * *}$ & $58.724,11^{* * *}$ \\
\hline $\mathrm{n}^{\circ}$ de obs. & 55.265 & 55.265 & 55.265 & 58.378 & 58.378 & 58.378 \\
\hline
\end{tabular}


Cinco variáveis são utilizadas para representar o número de filhos: filhos de 0 a 2 anos de idade (FILHO0-2), filhos de 3 a 5 anos de idade (FILHO3-5), filhos de 6 a 12 anos de idade (FILHO6-12), filhos com 13 ou mais anos de idade (FILHO $>12$ ) e filhas com 13 ou mais anos de idade (FILHA $>12$ ). Estas variáveis são incluídas na equação de participação para refletir os custos monetários de cuidar dos filhos, e, portanto, sua interferência na participação dos pais no mercado de trabalho e, consequentemente, a interferência da presença de filhos na participação dos pais no mercado de trabalho.

Os coeficientes das variáveis representando a presença de filhos com até 5 anos de idade (FILHOO-2 e FILHO3-5) são positivos e significativos na equação de participação do homem nos 3 mercados de trabalho, indicando que estes filhos influenciam positivamente na participação do pai no mercado de trabalho, pois a presença de filhos na família aumenta os gastos, o que leva à necessidade de aumento da renda familiar.

Para a mulher (com exceção da mulher empregada no setor informal que tenha filho de 3 a 5 anos de idade), a presença de filhos tem forte efeito negativo em sua participação no mercado de trabalho. Foi encontrado coeficiente positivo e significativo para a mulher com FILHO3-5 no mercado de trabalho informal, no entanto isto faz sentido. É possível explicar este resultado devido às características inerentes ao emprego informal; maior flexibilidade de horário e maior possibilidade de sair do trabalho durante a jornada de trabalho, no caso das assalariadas, e total flexibilidade para as trabalhadoras por conta própria. Assim, mulheres com FILHO3-5, os quais não exigem tanto tempo de suas mães quanto os filhos com menos de 2 anos de idade, podem conciliar a tarefa de ser mãe e trabalhar no mercado informal.

A queda da participação da mulher no mercado de trabalho devido a presença de filhos muito novos é maior no mercado de trabalho formal. O aumento de 1 filho com menos de 2 anos de idade diminui a probabilidade da mulher participar do 
mercado de trabalho formal em 2,57 pontos percentuais, enquanto um FLLHO3-5 adicional diminui a probabilidade de participação em 1,87 pontos percentuais. $O$ impacto da presença de filhos de 0 a 5 anos é menor nos outros mercados de trabalho. Entre as trabalhadoras formais e empregadoras, um FILHOO-2 adicional decresce a probabilidade de participação no mercado de trabalho em $1,12 \%$ e $0,13 \%$ pontos percentuais, respectivamente. Um FILHO3-5 adicional aumenta a probabilidade da mulher participar do mercado de trabalho informal em 2,27 pontos percentuais, já que é possível conciliar o trabalho informal com a tarefa de cuidar destes filhos e mais, um filho adicional gera a necessidade de se aumentar a renda familiar. Para as empregadoras um FILHO3-5 adicional representa uma queda de 0,13 pontos percentuais na probabilidade de sua participação no mercado de trabalho.

A presença de FILHO6-12 diminui a participação dos homens nos três mercados de trabalho. À primeira vista este resultado pode parecer estranho, mas, levando-se em consideração a estrutura do mercado de trabalho brasileira, onde a proporção de trabalhadores infantis no total de trabalhadores é alta, pode-se afirmar que este resultado reflete realmente a realidade do mercado de trabalho brasileiro, onde uma grande parte das crianças, assim que possibilitadas de trabalhar, participam do mercado de trabalho para complementar a renda da família. A partir dos dados da PNAD de 1995 verifica-se que $11,86 \%, 14,34 \%, 19,17 \%$ e $24,65 \%$ das crianças com idade de $10,11,12 \mathrm{e}$ 13 anos, respectivamente, são economicamente ativas. A presença de filhos com idade entre 6 e 12 anos diminui a probabilidade da mulher participar do mercado de trabalho formal, enquanto aumenta a probabilidade de participação no mercado informal.

Filhas e filhos com 13 ou mais anos de idade (FILHA $>12$ e FILHO $>12$ ) afetam negativamente a participação dos pais nos três mercados de trabalhos. No entanto este resultado deve indicar situações diferentes entre homem e mulher. O sinal negativo dos coeficientes das equações dos homens devẹm indicar que os filhos entram no mercado de trabalho complementando a renda familiar ou então tornando-se independentes financeiramente da renda do pai, desobrigando este das despesas 
financeiras dos filhos. Os coeficientes negativos das equações das mulheres devem indicar dois efeitos distintos: o primeiro seria dos filhos (as) substituírem a mão-de-obra das mães no mercado de trabalho, diminuindo assim, a necessidade da mãe ter que trabalhar, gerando renda para a família de modo a permitir que a mãe permaneça em casa cuidando da família e dos afazeres domésticos; o segundo seria não de substituição total da mão-de-obra da mãe no mercado de trabalho mas sim de complementação, como explicado anteriormente.

Kassouf (1997), estudando os determinantes da participação no mercado de trabalho brasileiro, constatou que a presença de crianças pequenas nos domicílios reduz a participação das mulheres no mercado de trabalho, mas por outro lado, aumenta a participação do homem no mercado de trabalho. Ela observou ainda que a presença de filhas adolescentes aumenta a participação das mães no mercado de trabalho, resultado diferente daquele encontrado neste trabalho, indicando que as adolescentes substituem as mães nos cuidados com as crianças. Por outro lado, filhos adolescentes têm efeito negativo na participação da mãe no mercado de trabalho, substituindo-as no mesmo.

Marcouiller et al. (1997) usando uma amostra de homens e mulheres de El Salvador concluíram que a presença de crianças muito pequenas não têm efeito na participação dos pais no mercado de trabalho formal da economia, enquanto para as mulheres este efeito é negativo, ou seja, diminui a probabilidade da mulher participar do mercado de trabalho formal.

Tiefenthaler (1994) também observou que no Brasil a presença de crianças muito pequenas, 0 a 5 anos de idade, têm efeito negativo sobre a participação da mulher no mercado de trabalho, sendo que este efeito é mais forte no setor formal da economia. Como neste trabalho, ela concluiu que filhos e filhas maiores de 12 anos de idade afetam negativamente a participação da mãe no mercado de trabalho, indicando que 
eles não substituem as mães nos cuidados das crianças pequenas, mas substituem a força de trabalho das mães no mercado de trabalho.

Hill (1989) usando uma amostra de mulheres japonesas, trabalhando no mercado de trabalho formal como empregadas e no mercado de trabalho informal (trabalhador familiar - produz bens no domićlio para a venda no mercado, trabalha na fazenda da família ou em pequenos negócios familiares), observou que a presença de crianças pequenas na família reduz a participação da mulher no mercado de trabalho formal e informal, sendo que o efeito é mais forte no mercado de trabalho formal.

Variáveis representando a posição do indivíduo na família (CHEFE, FILHO, CÔNJUGE e OUTROS - variável omitida) mostram que a participação de indivíduos classificados como filho é mais intensa no mercado informal quando comparada com a participação dos indivíduos chefes neste mesmo mercado. O contrário é observado para empregadores em que a participação dos CHEFES é maior neste segmento de trabalhadores do que a participação dos indivíduos classificados como filho. A participação da mulher classificada como filha é menor que a participação do homem (filho) tanto no mercado formal quanto no mercado informal.

O coeficiente encontrado para a variável CÔNJUGE indica que a posição da mulher na família como cônjuge reflete negativamente na sua participação no mercado de trabalho, o que é bastante comum na sociedade brasileira, pois uma grande parte das mulheres brasileiras casadas são financeiramente dependentes de seus maridos.

Kassouf (1997), usando variáveis representando a posição dos indivíduos na família (chefe, esposa, filho/filha e outros), mostrou que a participação do chefe (homem) no mercado de trabalho é maior que a participação dos filhos, e também que a participação das mulheres chefes é maior que a participação das esposas.

Marcouiller et al. (1997) observaram para El Salvador e México que a condição do homem como chefe do domicílio aumenta sua probabilidade de participar do 
mercado de trabalho formal, enquanto que a condição da mulher como chefe do domicílio aumenta sua probabilidade de trabalhar no setor formal em El Salvador e diminui no México.

A variável ESTADO CONJUGAL não apresenta o sinal esperado apenas na equação das mulheres empregadoras, porém, este coeficiente não se mostra estatisticamente significativo. Nas equações dos homens obteve-se o sinal esperado, ou seja, o fato do homem ser casado afeta positivamente a sua participação no mercado de trabalho. Nas equações das mulheres o efeito observado foi o contrário, ou seja, o fato da mulher ser casada afeta negativamente a sua participação no mercado de trabalho. Estes resultados são consistentes pois é uma característica da sociedade brasileira que a responsabilidade quanto às despesas da família seja do homem. Assim, o resultado obtido mostra que os homens casados tem maior probabilidade de participar do mercado de trabalho do que os solteiros. Decorrente do que foi dito, observa-se para a mulher a situação inversa, ou seja, a probabilidade da mulher casada participar do mercado de trabalho é menor que da mulher solteira. Este resultado é decorrente do fato de grande parte das mulheres casadas serem dependentes de seus maridos.

Marcouiller et al. (1997) constataram que em El Salvador o indivíduo ser casado, tanto o homem quanto a mulher, afeta positivamente a probabilidade deste participar do mercado de trabalho formal. No México a mulher casada têm menor probabilidade de trabalhar no setor formal, enquanto que a probabilidade de trabalhar no mercado de trabalho formal aumenta para os homens casados. Este último resultado é semelhante àquele por nós encontrado.

EXPERIÊNCIA é incluída na equação de participação para refletir os efeitos de investimentos em capital humano, o qual afeta a participação. Como esperado, a experiência tem efeito positivo e significativo nas 6 equações estimadas. Uma interpretação para este resultado é que com o aumento da experiência, o nível de capital humano adquirido aumenta, o que deve afetar positivamente o nível salarial. $\mathrm{O}$ aumento 
salarial, tudo mais constante, deverá aumentar a participação dos indivíduos no mercado de trabalho. A variável experiência ao quadrado é incluída para captar uma possível relação não linear entre experiência e participação no mercado de trabalho. Encontrou-se coeficientes significativos e negativos para todas as 6 equações, indicando que existe uma relação parabólica entre experiência e participação. Os resultados mostram que a medida em que o indivíduo ganha experiência, a probabilidade de participação no mercado de trabalho aumenta até atingir um ponto onde o capital humano começa a se depreciar, a partir deste ponto a probabilidade de participação começa a declinar, refletindo o fato de que a partir de uma determinada idade a produtividade dos indivíduos declina. Os resultados obtidos mostram que a experiência tem maior efeito na participação para as mulheres do que para os homens nos mercados formal e informal.

Kassouf (1997), Marcouiller et al. (1997), Tiefenthaler (1994) e Hill (1989) obtiveram os mesmos resultados aqui encontrados no que diz respeito aos efeitos da experiência sobre a participação no mercado de trabalho. Tiefenthaler e Hill usaram como proxy da experiência a idade dos indivíduos, Kassouf usou idadeescolaridade-6 para obter uma aproximação empírica da experiência dos indivíduos e Marcouiller et al. usaram para os homens anos de experiência (idade-escolaridade-6) e para as mulheres usaram como proxy da experiência a idade. Todos os pesquisadores obtiveram sinais positivos para experiência e negativo para experiência ao quadrado.

Kassouf (1997), como neste trabalho, encontrou efeito da experiência sobre a participação no mercado de trabalho maiores para as mulheres que para os homens, nos setores formal e informal da economia. Hill (1989) observou que os efeitos da experiência na participação do mercado de trabalho é maior para as trabalhadoras informais que para as trabalhadoras formais. Marcouiller et al. (1997) estudaram somente os efeitos da experiência sobre a probabilidade do indivíduo participar do mercado de trabalho formal, encontrando efeito positivo em todos os países por eles estudados, El Salvador, Peru e México. Tiefenthaler (1994) encontrou maior efeito da 
experiência sobre a participação no mercado de trabalho para as mulheres empregadas no setor formal da economia.

ESCOLARIDADE é incluída na equação de participação para refletir o efeito do salário na participação no mercado de trabalho. O aumento no número de anos de estudo eleva o nível de capital humano, o que deve afetar positivamente o nível salarial. O aumento salarial, tudo mais constante, deverá aumentar a participação dos indivíduos no mercado de trabalho. A variável ESCOLARIDADE afeta positivamente a participação do homem e da mulher na força de trabalho, sendo que o efeito é mais forte para os indivíduos que trabalham no mercado formal e para os empregadores. Entretanto, podemos observar que o aumento de 1 ano de estudo decresce em 2,8 pontos percentuais a probabilidade de participação dos homens no mercado informal. Este resultado pode ser explicado pelo fato do aumento da escolaridade aumentar a propensão dos indivíduos conseguirem emprego no mercado de trabalho formal. Espera-se que a escolaridade tenha maiores retornos no mercado formal e para empregadores, pois os indivíduos com maior nível de escolaridade encontram mais oportunidades de emprego no mercado formal e possuem maiores chances de serem empregadores. Como mostra a Tabela 5, a média de anos de estudo dos homens é 7,25, 5,12 e 8,91 nos mercados formal, informal e para empregadores, respectivamente; enquanto para as mulheres esta média é de 8,89, 5,43 e 10,59 nos respectivos mercados de trabalho.

Kassouf (1997) e Hill (1989) encontraram sinais positivos e altamente significativos para a variável escolaridade, indicando que maiores anos de escolaridade aumenta a probabilidade de participação no mercado de trabalho. Marcouiller et al. (1997) também encontraram sinal positivo para a escolaridade, indicando que a probabilidade do indivíduo trabalhar no mercado formal aumenta com a escolaridade. Tiefenthaler (1994) observou que o aumento nos anos de estudo aumenta a probabilidade de participação da mulher no mercado de trabalho formal, entretanto diminui a probabilidade de participação da mulher no mercado de trabalho informal. 
O termo de interação EDUCEXP representa anos de estudo vezes anos de experiência. O sinal negativo indica que o efeito da escolaridade (experiência) diminui quando os anos de experiência (escolaridade) aumentam, ou seja, a importância do nível de escolaridade (experiência) para obtenção de emprego se torna menor quando o indivíduo tem uma grande experiência (escolaridade) em uma determinada área. Kassouf (1997), encontrou o mesmo resultado para os setores formal e informal da economia.

As variáveis binárias para os grupos de cor existentes no Brasil (Cor BRANCA e PARDA) foram incluídas nas equações de participação para refletir diferenças étnicas e valores culturais entre os indivíduos. O grupo de referência é o de cor preta (variável omitida na equação). Ao contrário do esperado, observa-se sinal negativo para o coeficiente estimado para a variável cor branca e parda, ou seja, os resultados mostram que os negros tem maior probabilidade de participar do mercado de trabalho formal do que os brancos e pardos. O oposto é observado para a categoria dos empregadores, ou seja, os brancos e pardos tem maior probabilidade de serem empregadores do que os negros. Explicação plausível para a probabilidade de participação do negro ser maior que a probabilidade da participação do branco no mercado de trabalho formal é que geralmente os negros entram mais cedo no mercado de trabalho, pois estudam menos que os brancos; os negros também aceitam salários muito baixos, aumentando a sua probabilidade de estar empregado; outra explicação está no fato de numa família de cor branca a probabilidade do chefe da família poder sustentar toda a família com seu salário ser maior que do chefe negro conseguir sustentar toda a família, de forma que, geralmente, na família negra todos os membros economicamente ativos têm que trabalhar.

Resultados semelhantes foram encontrados por Tiefenthaler (1994). Kassouf (1997) também encontrou resultados inesperados, como por exemplo sinais negativos e significativos dos coeficientes das variáveis cor branca e parda nas equações das mulheres, indicando que a probabilidade das mulheres brancas e pardas participarem dos mercados de trabalho formal e informal é menor que das negras. 
A variável binária para a posse da casa própria e a variável representando os rendimentos não salariais foram incluídas nas equações estimadas, como proxies da riqueza. Espera-se que estas variáveis, por representarem o nível de riqueza dos indivíduos, tenham efeito negativo sobre a participação dos indivíduos no mercado de trabalho nos três segmentos analisados. CASA PRÓPRIA, como pode ser observado na Tabela 10, tem efeito negativo sobre a participação dos indivíduos nos mercados formal e informal. Para empregadores o coeficiente encontrado não é estatisticamente significativo. Resultados semelhantes foram encontrados por Tiefenthaler (1994).

RENDA NÃO SALARIAL também tem efeito negativo e bastante significativo na participação para os três segmentos de trabalhadores. Aumentando a renda não salarial em 100 reais por mês, a probabilidade de participação dos homens decresceria em 2,2, 1,1 e 0,2 pontos percentuais nos mercados formal, informal e empregadores, respectivamente. Para as mulheres o mesmo aumento decresceria sua participação em 2,7, 1,7, e 0,02 pontos percentuais para os respectivos segmentos (formal, informal e empregadores). Observa-se então que o impacto da renda não salarial é maior para os trabalhadores formais e menor para os empregadores e, o efeito negativo dos rendimentos não salariais é maior para as mulheres do que para os homens.

Resultados bastante similares a estes foram encontrados por Kassouf (1997) e Tiefenthaler (1994). Tiefenthaler concluiu que o efeito negativo da renda não salarial para as mulheres é maior no mercado de trabalho formal, resultado idêntico ao aqui encontrado.

As variáveis binárias para as 5 regiões brasileiras foram incluídas para verificar as diferenças regionais no que diz respeito aos três segmentos de trabalho. Analisando os resultados observa-se que metade dos coeficientes não são estatisticamente significativos. Ainda assim, foi possível confirmar que existem diferenças entre as regiões. A região de referência é a Nordeste (variável omitida). Na Região Norte o único coeficiente significativo encontrado é na equação dos empregadores, o sinal é positivo, 
indicando que a oportunidade de ser empregador é maior na Região Norte do que na Região Nordeste. Na Região Sul, Sudeste e Centro-Oeste os indivíduos (homem e mulher) têm menor probabilidade de participar do mercado de trabalho informal do que os indivíduos residentes na Região Nordeste, como é mostrado pelos coeficientes negativos nas duas equações de participação no mercado de trabalho informal. Este resultado é confirmado pelas proporções de trabalhadores em cada mercado de trabalho e região, dados na Tabela 6. As oportunidades de emprego no mercado de trabalho formal são maiores nas regiões mais desenvolvidas do país, enquanto as oportunidades de emprego no mercado de trabalho informal são maiores nas regiões menos desenvolvidas.

Tiefenthaler (1994) e Kassouf (1997) verificaram resultados semelhantes. Segundo Kassouf há uma relação positiva entre as regiões Sudeste, Sul e Centro-Oeste e participação no mercado de trabalho formal da economia, enquanto oportunidades de emprego no mercado de trabalho informal são maiores nas regiões menos desenvolvidas. De acordo com Tiefenthaler, no Rio de Janeiro, Norte e Nordeste é menos provável que a mulher encontre trabalho no setor formal que nas regiões mais industrializadas.

Para a Região Sudeste encontrou-se, nas equações dos empregadores coeficientes negativos e estatisticamente significativos, o que vai contra as expectativas. $\mathrm{Na}$ Região Centro-Oeste foram encontrados resultados não esperados para as trabalhadoras formais e empregadoras, os coeficientes são negativos e estatisticamente significativos. Estes resultados indicam que empregadores encontram mais oportunidades desses trabalhos na Região Nordeste que na Região Sudeste, e trabalhadoras formais e empregadoras encontram mais oportunidade desses trabalhos na Região Nordeste que na Região Centro-Oeste, o que vai contra todos os estudos realizados. 


\subsection{Funções de rendimentos para os mercados de trabalho formal e informal e para empregadores}

A Tabela 11 apresenta os resultados das estimativas das funções de rendimentos para homens e mulheres nos três segmentos do mercado de trabalho da economia: formal, informal e empregadores ${ }^{19}$. A variável dependente é o logaritmo neperiano do salário/hora de cada indivíduo participando do mercado de trabalho. As estatísticas-t são precisas, pois os desvios padrões e as estatísticas-t foram recalculadas usando a matriz de covariância estimada, que é consistente na presença de heterocedasticia. As equações de rendimento foram estimadas pelo método dos mínimos quadrados, ponderando-se pelo fator de expansão da amostra ${ }^{20}$. A correção para viés de seletividade amostral foi feita usando a variável LAMBDA (inverso da razão de Mill), para a obtenção de estimativas consistentes dos parâmetros.

O nível da taxa de salário/hora pode ser explicado como função das características individuais e características do trabalho. Características individuais são determinadas para mensurar a produtividade do trabalho, enquanto características do trabalho explicam diferenças nos mecanismos de fixação dos salários. Como usualmente, características individuais incluem anos de estudo (ESCOLARIDADE) e EXPERIENCIA, as quais fornecem informações sobre o estoque de capital humano. Para a variável experiência, especificou-se um termo quadrático (EXPERIÊNCIA2) de maneira a captar formas não lineares nos retornos à experiência. Características individuais também incluem a raça à qual pertence o indivíduo ( $R$. BRANCA, $R$.

${ }^{19}$ Realizou-se o teste de Chow para testar a hipótese de que os coeficientes estimados das regressões para os homens e mulheres são iguais - $\beta_{H}=\beta_{M}$. Os resultados obtidos foram os seguintes:

Mercado de trabalho formal: $F[15, \infty]=222,85$

Mercado de trabalho informal: $F[15, \infty]=108,30$

Empregadores: $\mathrm{F}[15, \infty]=2,00$

O valor crítico tabelado a $5 \%$ de confiança é 1,67. Portanto rejeito a hipótese de que $\beta_{H}=\beta_{M}$, ou seja, pelo menos alguns ou todos os coeficientes de regressão são diferentes. O procedimento correto é dividir a amostra total em duas, uma para os homens e outra para as mulheres.

${ }^{20}$ A pesquisa possui uma variável que é o peso da pessoa na amostra, isto é, cada indivíduo entrevistado representa um determinado número de indivíduos, de forma que a soma dos pesos resulta na população total. 
Tabela 11. Funções de Rendimentos para homens e mulheres nos mercados de trabalho formal e informal e para empregadores.

\begin{tabular}{|c|c|c|c|c|c|c|}
\hline & \multicolumn{3}{|c|}{ Homem } & \multicolumn{3}{|c|}{ Mulher } \\
\hline Variáveis & Formal & Informal & Empregador & Formal & Informal & Empregador \\
\hline CONSTANTE & $\begin{array}{c}-2,10 \\
(-45,31)^{* * *}\end{array}$ & $\begin{array}{c}-2,39 \\
(-29,88)^{* * *}\end{array}$ & $\begin{array}{c}2,58 \\
(4,89)^{* * *}\end{array}$ & $\begin{array}{c}-2,66 \\
(-54,79)^{* * *}\end{array}$ & $\begin{array}{c}-2,02 \\
(-19,46)^{* * *}\end{array}$ & $\begin{array}{c}2,14 \\
(2,14)^{* *}\end{array}$ \\
\hline LAMBDA & $\begin{array}{c}0,432 \\
(11,28)^{* * *}\end{array}$ & $\begin{array}{c}1,15 \\
(23,56)^{* * *}\end{array}$ & $\begin{array}{c}-0,818 \\
(-6,09)^{* * *}\end{array}$ & $\begin{array}{c}0,509 \\
(51,45)^{* * *}\end{array}$ & $\begin{array}{c}0,335 \\
(10,56)^{* * *} \\
\end{array}$ & $\begin{array}{c}-0,601 \\
(-2,99)^{* * *}\end{array}$ \\
\hline ESCOLARIDADE & $\begin{array}{c}0,147 \\
(47,11)^{* * *}\end{array}$ & $\begin{array}{c}0,0441 \\
(12,46)^{* * *}\end{array}$ & $\begin{array}{c}0,0557 \\
(3,69)^{* * *}\end{array}$ & $\begin{array}{c}0,181 \\
(48,65)^{* * *}\end{array}$ & $\begin{array}{c}0,114 \\
(44,89)^{* * *}\end{array}$ & $\begin{array}{c}0,0636 \\
(2,28)^{* *}\end{array}$ \\
\hline EXPERIÊNCIA & $\begin{array}{c}0,0512 \\
(24,52)^{* * *}\end{array}$ & $\begin{array}{c}0,0497 \\
(16,27)^{* * *}\end{array}$ & $\begin{array}{c}0,0101 \\
(0,96)\end{array}$ & $\begin{array}{c}0,0652 \\
(20,84)^{* * *}\end{array}$ & $\begin{array}{c}0,0463 \\
(10,66)^{* * *}\end{array}$ & $\begin{array}{l}-0,0247 \\
(-1,25)\end{array}$ \\
\hline EXPERIÊNCIA2 & $\begin{array}{l}-0,000706 \\
(-23,43)^{* * *}\end{array}$ & $\begin{array}{l}-0,000650 \\
(-14,82)^{* * *}\end{array}$ & $\begin{array}{c}-0,000135 \\
(-1,07)\end{array}$ & $\begin{array}{l}-0,000847 \\
(-17,32)^{* * *}\end{array}$ & $\begin{array}{l}-0,000550 \\
(-8,63)^{* * *}\end{array}$ & $\begin{array}{l}0,000652 \\
(2,50)^{* * *}\end{array}$ \\
\hline EDUCEXP & $\begin{array}{c}-0,000244 \\
(-2,37)^{* *}\end{array}$ & $\begin{array}{l}0,000426 \\
(3,59)^{* * *}\end{array}$ & $\begin{array}{c}-0,00388 \\
(-1,07)\end{array}$ & $\begin{array}{c}-0,00106 \\
(-10,28)^{* * *}\end{array}$ & $\begin{array}{l}-0,00134 \\
(-8,28)^{* * *}\end{array}$ & $\begin{array}{c}-0,000550 \\
(-0,74)\end{array}$ \\
\hline R. BRANCA & $\begin{array}{c}0,149 \\
(6,23)^{* * *}\end{array}$ & $\begin{array}{c}0,326 \\
(11,20)^{* * *}\end{array}$ & $\begin{array}{c}-0,288 \\
(-2,57)^{* * *}\end{array}$ & $\begin{array}{c}0,0706 \\
(2,41)^{* *}\end{array}$ & $\begin{array}{c}0,202 \\
(6,21)^{* * *}\end{array}$ & $\begin{array}{l}-0,132 \\
(-0,44)\end{array}$ \\
\hline R. PARDA & $\begin{array}{c}0,0156 \\
(0,64)\end{array}$ & $\begin{array}{c}0,123 \\
(4,13)^{* * *}\end{array}$ & $\begin{array}{c}-0,226 \\
(-2,27)^{* *}\end{array}$ & $\begin{array}{l}-0,0537 \\
(-1,82)^{*}\end{array}$ & $\begin{array}{c}0,0256 \\
(0,77) \\
\end{array}$ & $\begin{array}{c}-0,0836 \\
(-0,29)\end{array}$ \\
\hline R. NORTE & $\begin{array}{c}0,166 \\
(8,10)^{* * *} \\
\end{array}$ & $\begin{array}{c}0,290 \\
(10,01)^{* * *}\end{array}$ & $\begin{array}{c}-0,0491 \\
(-0,75) \\
\end{array}$ & $\begin{array}{c}0,307 \\
(10,39)^{* * *}\end{array}$ & $\begin{array}{c}0,264 \\
(8,23)^{* * *} \\
\end{array}$ & $\begin{array}{c}0,532 \\
(3,93)^{* * *} \\
\end{array}$ \\
\hline R. SUL & $\begin{array}{c}0,304 \\
(18,07)^{* * *}\end{array}$ & $\begin{array}{c}-0,000814 \\
(-0,04)\end{array}$ & $\begin{array}{l}0,0303 \\
(0,59)\end{array}$ & $\begin{array}{c}0,319 \\
(14,42)^{* * *}\end{array}$ & $\begin{array}{c}0,262 \\
(10,56)^{* * *}\end{array}$ & $\begin{array}{c}0,108 \\
(1,08) \\
\end{array}$ \\
\hline R. SUDESTE & $\begin{array}{c}0,439 \\
(33,34)^{* * *}\end{array}$ & $\begin{array}{c}0,120 \\
(5,78)^{* * *}\end{array}$ & $\begin{array}{c}0,215 \\
(4,80)^{* * *} \\
\end{array}$ & $\begin{array}{c}0,426 \\
(24,43)^{* * *}\end{array}$ & $\begin{array}{c}0,429 \\
(20,96)^{* * *}\end{array}$ & $\begin{array}{c}0,452 \\
(5,20)^{* * *} \\
\end{array}$ \\
\hline $\begin{array}{l}\text { R. CENTRO } \\
\text { OESTE }\end{array}$ & $\begin{array}{c}0,318 \\
(16,88)^{* * *}\end{array}$ & $\begin{array}{c}0,139 \\
(5,47)^{* * *}\end{array}$ & $\begin{array}{c}-0,0426 \\
(-0,74)\end{array}$ & $\begin{array}{c}0,335 \\
(12,81)^{* * *}\end{array}$ & $\begin{array}{c}0,190 \\
(6,60)^{* * *}\end{array}$ & $\begin{array}{l}0,115 \\
(0,96)\end{array}$ \\
\hline $\begin{array}{l}\text { SETOR } \\
\text { SECUNDÁRIO }\end{array}$ & $\begin{array}{c}0,439 \\
(21,41)^{* * *}\end{array}$ & $\begin{array}{c}0,484 \\
(22,52)^{* * *}\end{array}$ & $\begin{array}{c}0,0572 \\
(1,07)\end{array}$ & $\begin{array}{c}0,224 \\
(4,00)^{* * *}\end{array}$ & $\begin{array}{l}0,184 \\
(3,01)\end{array}$ & $\begin{array}{l}0,0655 \\
(0,32)\end{array}$ \\
\hline $\begin{array}{l}\text { SETOR } \\
\text { TERCIÁRIO }\end{array}$ & $\begin{array}{c}0,309 \\
(15,19)^{* * *}\end{array}$ & $\begin{array}{c}0,502 \\
(24,50)^{* * *}\end{array}$ & $\begin{array}{c}0,119 \\
(2,40)^{* *}\end{array}$ & $\begin{array}{c}0,150 \\
(2,73)^{* * *}\end{array}$ & $\begin{array}{c}0,284 \\
(5,12)^{* * *}\end{array}$ & $\begin{array}{c}0,0906 \\
(0,47)\end{array}$ \\
\hline SINDICATO & $\begin{array}{c}0,237 \\
(26,24)^{* * *} \\
\end{array}$ & $\begin{array}{c}0,201 \\
(10,97)^{* * *}\end{array}$ & $\begin{array}{c}0,250 \\
(6,27)^{* * *} \\
\end{array}$ & $\begin{array}{c}0,269 \\
(20,51)^{* * *}\end{array}$ & $\begin{array}{c}0,379 \\
(13,11)^{* * *}\end{array}$ & $\begin{array}{c}0,389 \\
(5,12)^{* * *} \\
\end{array}$ \\
\hline $\mathbf{R}^{2}$ & 0,49 & 0,38 & 0,23 & 0,50 & 0,30 & 0,22 \\
\hline teste F & $1609,29^{* * *}$ & $894,32^{* * *}$ & $74,89^{* * *}$ & $1064,72^{* * *}$ & $447,26^{* * *}$ & $18,11^{* * *}$ \\
\hline$n^{0}$ de obs. & 23.459 & 20.658 & 3.584 & 14.903 & 14.369 & 920 \\
\hline
\end{tabular}


PARDA e R. NEGRA - cuja variável foi omitida). As características do trabalho incluídas são os setores de atividade econômica (S. PRIMÁRIO - variável omitida, S. SECUNDÁRIO e S. TERCIÁRIO), e a filiação do trabalhador a algum sindicato (SINDICATO), as quais foram incluídas no modelo a partir da especificação de variáveis binárias para cada uma das características. Para completar a especificação foram adicionadas variáveis binárias para a região de residência dos indivíduos ( $R$. SUDESTE, R. SUL, R. CENTRO-OESTE, R. NORTE e R. NORDESTE, a qual foi omitida na equação).

A variável LAMBDA foi calculada para cada indivíduo com base nos coeficientes estimados das equações de participação na força de trabalho, apresentados na Tabela 10. Esta variável apresentou coeficientes altamente significativos, indicando que sua inclusão no modelo era necessária para evitar problemas de tendenciosidade nas estimativas dos parâmetros causados pela seletividade amostral. O sinal negativo do coeficiente da variável LAMBDA para os mercados de trabalho formal e informal indica que os fatores não mensuráveis que aumentam a probabilidade de participação no mercado de trabalho diminuem a taxa de salário.

Os resultados encontrados tiveram os sinais corretos e alta significância estatística para as equações dos trabalhadores formais e informais, tanto para os homens quanto para as mulheres. Entretanto, os resultados obtidos nas duas equações dos empregadores foram ruins. São poucos os coeficientes estatisticamente significativos, o que é decorrente dos altos desvios padrões observados para a grande maioria dos coeficientes estimados, sendo que alguns apresentaram os sinais contrários ao esperado (EXPERIÊNCIA e EXPERIÊNCIA2 para a mulher, R. PARDA para homens). $O$ coeficiente de determinação encontrado para estas 2 equações foi substancialmente menor que aqueles obtidos nas demais equações, como pode ser visto na Tabela 11. Os resultados ruins encontrados talvez possam ser explicados devido ao fato das características que afetam os rendimentos dos empregadores serem bastante diferentes dos demais trabalhadores. Os rendimentos dos empregadores são afetados 
principalmente pelo volume do capital empregado na atividade produtiva, sendo dado pelo retorno do capital empregado, pelo número de trabalhadores e a produtividade de seu trabalho, pelo nível de preço alcançado pelo seu produto no mercado, etc.. Devido a natureza dos dados utilizados nesta pesquisa estes fatores não puderam ser medidos, pois tais dados não são apresentados na PNAD. Assim, a omissão de variáveis podem levar à coeficientes estimados tendenciosos.

A partir de tudo o que foi dito acima conclui-se que os resultados encontrados para as equações de empregadores são um tanto quanto duvidosos. Fazer inferências a partir dos coeficientes estimados podem resultar em conclusões erradas. Assim, na discussão dos resultados concentra-se apenas nas equações estimadas para os trabalhadores formais e informais.

Foram encontrados coeficientes positivos e altamente significativos para a variável ESCOLARIDADE. O aumento de anos de estudo aumenta os salários dos trabalhadores formais e informais. Observe que os valores dos coeficientes e os testes-t são maiores no mercado formal que no mercado informal, indicando que o estudo é mais valorizado no mercado de trabalho formal. Kassouf (1997) chegou a este mesmo resultado. Entretanto, o contrário foi observado por Tiefenthaler (1994), ou seja, os retornos da escolaridade por ela encontrados foram maiores no setor informal.

Pero (1994) constatou que o grau de formalização, entre os trabalhadores brasileiros, cresce com o nível educacional. Verificou também que o nível de renda é maior para os grupos de indivíduos com mais instrução.

Marcouiller et al. (1997) constataram que a propensão de ser trabalhador informal declina com o aumento dos anos de estudo nos 3 países por eles analisados: El Salvador, Peru e México. Observaram, a partir das equações de salário estimadas, que os retornos do estudo são maiores no setor formal do que no setor informal para homens e mulheres nos 3 países, exceto para as mulheres peruanas, as 
quais têm maior retorno do estudo no setor informal da economia. As taxas de retorno do estudo por eles encontradas variam de 4 a $8 \%$ para as mulheres e para os homens variam de 6 a $11 \%$.

Hill (1989) encontrou taxa de retorno por ano adicional de estudo maior para as mulheres no mercado de trabalho informal, aproximadamente 19\%, enquanto a taxa de retorno encontrada para as mulheres empregadas no mercado de trabalho formal foi de aproximadamente de $6 \%$.

Os coeficientes estimados para a variável EXPERIÊNCIA é positivo e para EXPERIÊNCIA2 é negativo, como sugerido pela teoria do capital humano, a qual declara que a função de rendimentos possui uma curva parabólica, onde os rendimentos alcançam um valor máximo em algum ponto da vida do indivíduo a partir do qual começa o processo de depreciação do capital humano, o que se reflete na produtividade dos trabalhadores que começa a declinar e consequentemente o nível de salário a partir deste ponto cai.

O termo de interação entre experiência e escolaridade (EDUCEXP) apresentou sinal negativo e significativo para homens empregados formalmente e para as mulheres nos mercados formais e informais, indicando que para estes, o efeito da escolaridade (experiência) diminui quando os anos de experiência (escolaridade) aumenta. Para os homens no mercado informal encontrou-se sinal positivo, indicando que o efeito da escolaridade (experiência) aumenta quando os anos de experiência (escolaridade) aumentam. Nas regressões de rendimento estimadas por Kassouf (1997), os coeficientes da variável educexp foram negativos em todas as equações, para homens e mulheres nos 2 setores da economia.

As variáveis binárias para grupos de cor são significativas na maioria das equações estimadas. Os coeficientes são interpretados em relação aos indivíduos de cor preta (variável omitida). Os resultados indicam que os negros recebem salários menores que os brancos e pardos. Observa-se ainda que os coeficientes 
encontrados para os brancos são maiores que os coeficientes encontrados para os pardos, mostrando que os brancos não estão em situação favorável apenas em relação aos negros, mas também em relação aos pardos e, a diferença salarial é maior entre brancos e negros que entre pardos e negros.

As equações estimadas evidenciam diferenças regionais nos salários de todos os trabalhadores. É importante lembrar que as taxas de salário/hora usadas na regressão não foram ajustadas para refletir as diferenças nos custos de vida entre as regiões.

Homens e mulheres trabalhando na Região Nordeste (variável omitida) recebem salários menores que trabalhadores residentes nas demais regiões brasileiras (Sudeste, Sul, Centro-Oeste e Norte), nos dois mercados de trabalho, formal e informal. Estes resultados podem ser vistos na Tabela 11, onde os coeficientes para as regiões são todos positivos e significativos (exceto para trabalhadores do sexo masculino na Região Sul, sinal é negativo e não significativo). No mercado de trabalho formal, os homens recebem 16,6\%, 30,4\%, 43,9\% e 31,8\% a mais nas regiões Norte, Sul, Sudeste e Centro-Oeste, respectivamente, que na Região Nordeste. No mercado de trabalho informal os salários dos homens são maiores nas regiões Norte (29\%), Sudeste (12\%) e Centro-Oeste $(13,9 \%)$ quando comparados com os salários da Região Nordeste.

As mulheres recebem, no mercado de trabalho formal salários mais altos em 30,7\%, 31,9\%, 42,6\% e 33,5\% nas regiões Norte, Sul, Sudeste e CentroOeste, respectivamente, que na Região Nordeste. No mercado informal os salários das mulheres são maiores 26,4\% (Norte), 26,2\% (Sul), 42,9\% (Sudeste) e 19\% (CentroOeste) que na Região Nordeste.

Verifica-se portanto que os trabalhadores formais obtêm salários mais altos nas regiões mais desenvolvidas, enquanto os trabalhadores informais (excluindo-se a Região Nordeste) são mais bem remunerados nas regiões menos desenvolvidas, exceto as mulheres com empregos informais, que obtêm os rendimentos 
mais elevados na Região Sudeste, indicando que a mulher empregada no mercado de trabalho informal na região mais desenvolvida do país não possui condições de trabalho tão precárias quanto os homens nesta mesma região. Daí, pode-se inferir que as diferenças salariais entre os mercados de trabalho formal e informal são maiores nas regiões mais desenvolvidas. Revendo a Tabela 6 pode-se observar que os trabalhadores informais concentram-se nas regiões menos desenvolvidas e, verifica-se agora, que, nestas mesmas regiões, os diferenciais de salário entre os dois segmentos de mercado de trabalho são menores. Conclui-se, assim, que o diferencial de salário entre os dois mercados de trabalho está diretamente relacionado com o grau de desenvolvimento das regiões, ou seja, em regiões mais desenvolvidas o diferencial de salário é maior que o diferencial de salário verificado nas regiões menos desenvolvidas.

Kassouf (1997) concluiu que homens e mulheres trabalhando no setor formal auferem rendimentos inferiores na Região Nordeste em relação às regiões Norte, Centro-Oeste, Sul e Sudeste. O homem trabalhando no setor informal têm rendimentos inferiores nas regiões mais desenvolvidas em relação à Região Nordeste, enquanto as mulheres no setor informal auferem rendimentos superiores nas regiões mais desenvolvidas.

Tiefenthaler (1994) constatou que as mulheres, tanto as casadas como as solteiras, recebem salários menores na Região Nordeste em relação à Região Sul.

As variáveis binárias para setores de atividade da economia (SETOR PRIMÁRIO - variável omitida, SETOR SECUNDÁRIO e SETOR TERCIÁRIO) foram incluídas nas equações para verificar a existência de diferenças salariais dentro dos três grandes setores de atividades produtivas da economia.

A análise é feita em relação ao setor primário. Todos os coeficientes estatisticamente significativos encontrados possuem sinal positivo, indicando que no setor primário os trabalhadores recebem remuneração menor que nos 
dois outros setores. Os homens que trabalham no setor secundário recebem salários maiores que os trabalhadores do setor primário, $43,9 \%$ e $48,4 \%$, nos mercados de trabalho formal e informal, respectivamente. As mulheres empregadas formalmente têm salário $22,4 \%$ maior no setor secundário que no primário.

Os homens empregados no setor terciário recebem salários $30,9 \%$ (formais) e $50,2 \%$ (informais) maiores que os homens empregados no setor primário. As mulheres que trabalham no setor terciário recebem salários maiores que as empregadas no setor primário, $15 \%$ e $28,4 \%$, nos mercados formais e informais respectivamente.

Pode-se observar que a remuneração dos trabalhadores formais é maior no setor secundário que no setor terciário enquanto a remuneração dos trabalhadores informais é ligeiramente superior no setor terciário. Revendo a Tabela 6 verifica-se que no setor terciário quase a metade dos trabalhadores são informais, enquanto no setor secundário os trabalhadores são predominantemente formais, $60 \%$ dos trabalhadores neste setor estão no mercado de trabalho formal e apenas 35\% estão no mercado informal. Talvez a maior concentração de trabalhadores informais no setor terciário não seja explicada apenas pelo fato deste setor ofertar maior quantidade de empregos com contratos informais de trabalho. Uma possível explicação está no fato dos trabalhadores informais encontrarem melhor remuneração no setor terciário que o setor secundário.

A variável binária SINDICATO representa os trabalhadores que são filiados a algum sindicato. Todos os coeficientes estimados são positivos e altamente significativos, indicando que os trabalhadores sindicalizados estão em melhores condições de trabalho que os demais. Os salários dos trabalhadores sindicalizados são maiores $23,7 \%$ (formais) e $20,1 \%$ (informais) para os homens e, para as mulheres sindicalizadas os salários são mais altos $26,9 \%$ e $37,9 \%$ nos mercados formais e informais, respectivamente. Observa-se que o aumento no salário das mulheres 
sindicalizadas é substancialmente maior que o aumento observado para os homens. Os trabalhadores filiados a algum sindicato recebem salários maiores pois o movimento dos sindicatos dos trabalhadores é no sentido de se fazer cumprir as leis e regulamentações que protegem os trabalhadores, além disso o movimento dos trabalhadores sindicalizados realizando protestos e greves para reivindicar aumentos ou reajustes salariais é muito mais forte que movimentos onde não existe um sindicato que organize as manifestações.

\subsubsection{Retornos à experiência e escolaridade}

Considere a seguinte equação:

$\ln Y=\alpha+\beta_{1} \exp +\beta_{2} \exp ^{2}+\beta_{3} e d u c+\beta_{4} \exp \times e d u c+\varepsilon$

onde $Y$ é a taxa de rendimento hora, exp é a experiência em anos e educ representa anos de estudo. A equação possui forma linear na escolaridade mas quadrática na experiência.

A teoria do capital humano sugere que os rendimentos geralmente não são constantes após os indivíduos deixarem a escola, as funções de rendimento devem ter formato côncavo na experiência, isto é, em algum ponto da vida os indivíduos atingem o máximo rendimento, a partir do qual, este começa a declinar. É esperado coeficiente positivo para $\beta_{1}$ e negativo para $\beta_{2}$. Além disso, a teoria assume que as funções rendimento são lineares na escolaridade e que os efeitos da experiência nos rendimentos depende não somente da experiência como também da escolaridade, ou seja, espera-se que os indivíduos com maior nível de escolaridade recebam mais treinamento no trabalho que os menos educados. Uma forma de incorporar este efeito é adicionar às equações de rendimento o termo de interação entre escolaridade e experiência [ver Mincer (1974) e Becker (1962)]. 
Para obtermos o efeito da experiência no logaritmo dos rendimentos fazemos a derivada parcial de $\ln Y$ em relação à experiência,

$\frac{\partial \ln Y}{\partial \exp }=\beta_{1}+2 \beta_{2} \exp +\beta_{4}$ educ

e, para obtermos o efeito da escolaridade no logaritmo dos rendimentos derivamos $\ln Y$ em relação à escolaridade,

$\frac{\partial \ln Y}{\partial e d u c}=\beta_{3}+\beta_{4} \exp$

Como exemplo, considere a equação de rendimento para o homem no mercado de trabalho formal dada na coluna 1 da Tabela 11 . O efeito da experiência no logaritmo dos rendimentos é,

$\frac{\partial \ln Y}{\partial \exp }=0,0512-2 \times 0,000706 \times \exp -0,000244 \times$ educ

o qual é, considerando 4 anos de escolaridade, 4,46\% com 4 anos de experiência, 3,89\% com 8 anos de experiência e 3,33\% com 12 anos de experiência.

A Tabela 12 mostra os retornos porcentuais da experiência para homem e mulher nos mercados de trabalho formal e informal e para os empregadores, os quais foram calculados com base nos resultados da Tabela 11. Os resultados encontrados mostram que os retornos à experiência são positivos e declinam com aumentos nos anos de experiência e de escolaridade, exceto para os homens no mercado de trabalho informal, para os quais os retornos à experiência crescem com o nível de escolaridade. Este resultado deve-se ao fato do coeficiente do termo de interação das variáveis experiência e escolaridade (educexp) ser positivo para os homens no mercado de trabalho informal, indicando que os retornos obtidos com a experiência aumentam quando os anos de escolaridade aumentam. Os valores encontrados para retornos à 
experiência variam de $1,37 \%$ a $5,09 \%$ para os homens e de $0,01 \%$ a $5,15 \%$ para as mulheres.

Tabela 12. Retornos à experiência, em porcentagem, ao ano.

\begin{tabular}{|c|c|c|c|c|}
\hline \multirow[b]{2}{*}{ Experiência } & \multicolumn{2}{|c|}{ Mercado de trab. formal } & \multicolumn{2}{|c|}{ Mercado de trab. informal } \\
\hline & Homem & Mulher & Homem & Mulher \\
\hline & \multicolumn{4}{|c|}{ Escolaridade $=4$} \\
\hline 4 & 4,46 & 5,15 & 4,62 & 3,65 \\
\hline 8 & 3,89 & 4,47 & 4,11 & 3,21 \\
\hline 12 & 3,33 & 3,79 & 3,59 & 2,77 \\
\hline 16 & 2,77 & 3,12 & 3,07 & 2,33 \\
\hline 20 & 2,20 & 2,44 & 2,55 & 1,89 \\
\hline \multirow[t]{2}{*}{24} & 1,64 & 1,72 & 2,03 & 1,45 \\
\hline & \multicolumn{4}{|c|}{ Escolaridade $=8$} \\
\hline 4 & 4,36 & 4,72 & 4,80 & 3,12 \\
\hline 8 & 3,38 & 4,05 & 4,28 & 2,68 \\
\hline 12 & 3,23 & 3,37 & 3,76 & 2,24 \\
\hline 16 & 2,67 & 2,69 & 3,24 & 1,80 \\
\hline 20 & 2,10 & 2,02 & 2,72 & 1,37 \\
\hline \multirow[t]{2}{*}{24} & 1,54 & 1,33 & 2,20 & 0,92 \\
\hline & \multicolumn{4}{|c|}{ Escolaridade $=12$} \\
\hline 4 & 4,26 & 4,30 & 4,97 & 2,58 \\
\hline 8 & 3,70 & 3,63 & 4,45 & 2,14 \\
\hline 12 & 3,14 & 2,95 & 3,93 & 1,70 \\
\hline 16 & 2,57 & 2,27 & 3,41 & 1,26 \\
\hline 20 & 2,00 & 1,59 & 2,89 & 0,82 \\
\hline \multirow[t]{2}{*}{24} & 1,44 & 0,91 & 2,37 & 0,38 \\
\hline & \multicolumn{4}{|c|}{ Escolaridade $=15$} \\
\hline 4 & 4,19 & 3,99 & 5,09 & 2,18 \\
\hline 8 & 3,63 & 3,31 & 4,57 & 1,74 \\
\hline 12 & 3,06 & 2,63 & 4,05 & 1,30 \\
\hline 16 & 2,50 & 1,95 & 3,53 & 0,86 \\
\hline 20 & 1,93 & 1,28 & 3,01 & 0,42 \\
\hline 24 & 1,37 & 0,60 & 2,50 & 0,01 \\
\hline
\end{tabular}

${ }^{1}$ Os coeficientes $\beta_{1}, \beta_{2}$ e $\beta_{4}$ apresentaram-se todos não significativos a $10 \%$ para os homens empregadores, indicando que os coeficientes das variáveis experiência, experiência2 e educexp são iguais a zero, (ver Tabela 11).

Kassouf (1997) encontrou retornos à experiência variando de 2,69\% para o homem no mercado informal a 8,38\% para o homem no mercado formal e, para a mulher de $3,49 \%$ a $7,25 \%$ no mercado informal e formal, respectivamente. Vale destacar que Kassouf calculou retornos à experiência somente para 4, 8 e 12 anos de 
escolaridade e experiência. Marcouiller et al. (1997) encontraram retornos à experiência variando de 4 a $9 \%$ para as mulheres e de 3 a $6 \%$ para os homens, considerando o estudo por eles realizado em El Salvador, Peru e México. Hill (1989) verificou que o retorno à experiência para as mulheres japonesas era de aproximadamente $3 \%$ no setor formal e $2 \%$ no setor informal. Tiefenthaler (1994) estimou retornos à experiência em torno de $5 \%$ e $4 \%$ para as mulheres casadas no setor formal e informal, respectivamente. Para as mulheres solteiras os retornos foram de aproximadamente $3 \%$ no setor formal e $4 \%$ no setor informal.

Ademais, verifica-se maiores retornos à experiência para os homens no mercado de trabalho informal do que no formal. Os retornos obtidos no mercado de trabalho informal são maiores em até 3 vezes com relação aos retornos no mercado formal, sendo que as maiores diferenças de retorno à experiência entre os dois mercados de trabalho são observadas nos níveis de escolaridade maiores. Este resultado é totalmente diferente daquele encontrado por Kassouf (1997), em que os retornos à experiência, para homens no mercado de trabalho formal, são aproximadamente 3 vezes maiores que os retornos obtidos no mercado de trabalho informal. Este resultado pode ser explicado pela forma como a variável EXPERIÊNCIA foi obtida neste trabalho (experiência $=$ idade do indivíduo menos a idade que ele começou a trabalhar). Kassouf, como na maioria dos trabalhos que incluem experiência como variável, tomou como proxy da experiência a idade do indivíduo menos os anos de estudo menos 6, esta forma de obter a experiência para cada indivíduo assume que todo indivíduo inicia os estudos aos 6 anos de idade e começa a trabalhar logo que sai da escola. Acredita-se que a proxy da experiência usada nesta pesquisa seja uma melhor aproximação, pois, nem todo indivíduo começa a estudar aos 6 anos de idade e muitos não entram no mercado de trabalho assim que saem da escola. Ainda permanece o problema de não ser descontado os anos que a pessoa, após conseguir o seu primeiro emprego, fica desempregado ou por opção sai do mercado de trabalho. Entretanto, este problema existe nas duas formas de se obter os anos de experiência dos indivíduos. 
Os retornos à experiência para as mulheres são maiores no mercado de trabalho formal, $50 \%$ a 4 anos de escolaridade e 2 vezes maior a 15 anos de escolaridade, que no mercado de trabalho informal.

Observando o mercado de trabalho formal, vê-se que os retornos à experiência são maiores para as mulheres até escolaridade igual a 8 anos, a partir de 12 anos de escolaridade os retornos tornam-se maiores para os homens. No mercado de trabalho informal os retornos da experiência são maiores para os homens. Kassouf (1997) encontrou resultados bastante diferentes: no mercado formal as taxas de retorno eram maiores para os homens e no mercado de trabalho informal os retornos eram maiores para as mulheres.

Os retornos à escolaridade são apresentados na Tabela 13, variam de $4,58 \%$ para homens no mercado informal a $14,61 \%$ para o homem no mercado formal. Para as mulheres o retorno à escolaridade varia de $8,22 \%$, no mercado informal, a $17,71 \%$, no mercado formal. Os retornos à escolaridade encontrados são ligeiramente inferiores àqueles encontrados por Kassouf (1997). Ela encontrou retornos à escolaridade variando de 5,73\% para o homem no setor informal a $18,37 \%$ no setor formal, e para as mulheres retornos à escolaridade variando de $13,12 \%$ no setor informal a $21,17 \%$ no setor formal.

Tabela 13. Retornos à escolaridade, em porcentagem, ao ano.

\begin{tabular}{|c|c|c|c|c|c|c|}
\hline \multirow[b]{2}{*}{ Experiência } & \multicolumn{2}{|c|}{$\frac{\text { Mercado de trab. }}{\text { formal }}$} & \multicolumn{2}{|c|}{ Mercado de trab. informal } & \multicolumn{2}{|c|}{ Empregador } \\
\hline & Homem & Mulher & Homem & Mulher & Homem & Mulher \\
\hline 4 & 14,61 & 17,71 & 4,58 & 10,90 & 5,57 & 6,36 \\
\hline 8 & 14,51 & 16,29 & 4,75 & 10,36 & 5,57 & 6,36 \\
\hline 12 & 14,42 & 16,86 & 4,92 & 9,83 & 5,57 & 6,36 \\
\hline 16 & 14,32 & 16,44 & 5,09 & 9,29 & 5,57 & 6,36 \\
\hline 20 & 14,22 & 15,26 & 5,26 & 8,76 & 5,57 & 6,36 \\
\hline 24 & 14,12 & 15,59 & 5,43 & 8,22 & 5,57 & 6,36 \\
\hline
\end{tabular}

Os retornos à escolaridade são positivos e declinam com aumentos nos anos de experiência, exceto para homens no mercado de trabalho informal, 
para os quais o retorno à escolaridade aumenta com o aumento nos número de anos de estudo. Observe que os retornos à escolaridade são muito maiores do que os retornos à experiência, exceto para homens no mercado de trabalho informal. Os retornos à escolaridade obtidos no mercado de trabalho formal são aproximadamente 3 vezes e 2 vezes maiores que os retornos obtidos no mercado de trabalho informal, para homem e mulher respectivamente. Observa-se que os retornos à escolaridade são maiores para as mulheres nos dois mercados de trabalho.

Em relação aos empregadores pode-se notar que o retorno da escolaridade é baixo, comparado aos demais resultados, tanto para o homem quanto para a mulher. Estes resultados devem-se aos resultados obtidos na equação de rendimentos apresentados na Tabela 11, coluna 3 (para o homem) e coluna 6 (para as mulheres), onde apenas o coeficiente da variável escolaridade foi significativo, portanto o retorno é uma constante, independe dos anos de experiência (ver equação 22). Considerando-se que os mais altos níveis de escolaridade são verificados para a categoria dos empregadores (ver Tabela 5) pode-se dizer que este resultado é bastante estranho e duvidoso.

Tiefenthaler (1994) calculou retornos à escolaridade para mulheres casadas e solteiras, para empregadas no setor formal e informal e para trabalhadoras por conta própria, os resultados por ela encontrados são apresentados na Tabela 14.

Pode-se ver que os retornos à escolaridade, calculados por Tiefenthaler (1994), são bastantes altos. A mulher casada, no setor formal, com o primeiro grau completo recebe $91 \%$ a mais do que a mulher sem escolaridade, $116 \%$ a mais no setor informal, e a mulher casada que trabalha por conta própria recebe $100 \%$ a mais do que aquela sem escolaridade. As mulheres que possuem o grau universitário (solteiras e casadas) podem auferir aproximadamente 200 a $300 \%$ a mais em cada setor, em relação aquelas sem estudo. 
Tabela 14. Retornos à educação por níveis de escolaridade para mulheres casadas e solteiras, para empregadas no setor formal e informal e para trabalhadoras por conta própria, em porcentagem. ${ }^{1}$

\begin{tabular}{|c|c|c|c|c|c|c|}
\hline & \multicolumn{2}{|c|}{$\frac{\text { Empregadas no Setor }}{\text { Formal }}$} & \multicolumn{2}{|c|}{$\frac{\text { Empregadas no Setor }}{\text { Informal }}$} & \multicolumn{2}{|c|}{ Conta Própria } \\
\hline & Casada & Solteira & Casada & Solteira & Casada & Solteira \\
\hline primário incompleto & 13 & 25 & 25 & 33 & 22 & 22 \\
\hline primário completo & 42 & 48 & 57 & 61 & 58 & 49 \\
\hline primeiro grau completo & 91 & 99 & 116 & 119 & 100 & 103 \\
\hline segundo grau completo & 53 & 154 & 180 & 184 & 154 & 127 \\
\hline grau superior & 233 & 240 & 258 & 257 & 231 & 191 \\
\hline pós-graduação & 304 & 270 & 286 & 285 & 220 & 170 \\
\hline
\end{tabular}

Fonte: Tiefenthaler (1994)

${ }^{1}$ Os retornos calculados por Tiefenthaler foram calculados por grau de escolaridade e não para aumento de 1 ano de estudo.

Marcouiller et al. encontraram retornos à escolaridade por acréscimo de 1 ano de estudo em El Salvador para a mulher de 6,46\% (setor formal) e $4,13 \%$ (setor informal), e para os homens de 7,26\% (setor formal) e $6,14 \%$ (setor informal). No Peru os retornos por ano de estudo encontrados foram de $5,43 \%$ (setor formal) e $8,21 \%$ (setor informal) para mulheres, e $11,32 \%$ (setor formal) e 10,35\% (setor informal) para os homens. No México os retornos pelo aumento de 1 ano de estudo calculados, foram de $7,87 \%$ (setor formal) e 4,96\% (setor informal) para as mulheres, e para os homens $8,60 \%$ (setor formal) e $6,17 \%$ (setor informal).

Hill (1989) encontrou retornos por ano de estudo de aproximadamente $6 \%$ no setor formal e $19 \%$ no setor informal para as mulheres japonesas.

\subsubsection{Máximo rendimento}

Para obter o número de anos de experiência no qual os rendimentos atingem o valor máximo, igualamos a equação 21 a zero e resolvemos para a experiência a diferentes anos de escolaridade. Portanto, com 4, 8 e 12 anos de estudo, os homens empregados no mercado de trabalho formal maximizam os rendimentos do 
trabalho com 35,6, 34,9 e 34,2 anos de experiência. Estes resultados são apresentados na Tabela 15 para homem e mulher no mercado de trabalho formal e informal.

Tabela 15. Número de anos de experiência em que os rendimentos atingem o valor máximo, para homens e mulheres no mercado de trabalho formal e informal.

\begin{tabular}{cccccc}
\hline \multirow{2}{*}{ Escolaridade } & \multicolumn{2}{c}{ Mercado de trabalho formal } & & \multicolumn{2}{c}{ Mercado de trabalho informal } \\
\cline { 2 - 3 } & Homem & Mulher & & Homem & Mulher \\
\hline $\mathbf{4}$ & 35,6 & 36,0 & 39,5 & 37,2 \\
$\mathbf{8}$ & 34,9 & 33,5 & 40,9 & 32,4 \\
$\mathbf{1 2}$ & 34,2 & 30,0 & 42,2 & 27,5 \\
\hline
\end{tabular}

não foi possível calcular o número de anos de experiência onde o rendimento dos empregadores atinge o valor máximo pois para os homens $\beta_{1}, \beta_{2}$ e $\beta_{4}$ não são significativos e $\beta_{1}$ e $\beta_{4}$ não são significativos para as mulheres.

Analisando a Tabela 15 observa-se que, com exceção do homem no mercado de trabalho informal, o número de anos de experiência no qual os rendimentos atingem o valor máximo decrescem com o aumento nos anos de estudo, esta variação não é muito significativa para o homem no mercado de trabalho formal, o qual, com 4 anos de estudo atinge o máximo rendimento com 35,6 anos de experiência enquanto aquele com 12 anos de estudo atinge o valor máximo de rendimento com 34,2 anos de experiência. Nota-se então que o homem com maior escolaridade atinge maiores rendimentos com apenas 1,4 ano, aproximadamente, a menos de experiência que aqueles com apenas 4 anos de estudo. Para os homens que trabalham no mercado informal, o número de anos de experiência no qual seus rendimentos atingem o valor máximo aumenta com acréscimos de anos de estudo. Assim, os seus rendimentos atingem valor máximo com 39,5 anos de experiência e 4 anos de estudo e, 42,2 anos de experiência e 12 anos de estudo.

A mulher atinge o máximo rendimento com menos anos de experiência do que o homem nos dois mercados de trabalho. É importante notar que no mercado de trabalho informal o aumento de anos de estudo diminui significativamente 
o número de anos de experiência no qual a mulher atinge o máximo rendimento Com 4 anos de estudo a mulher atinge o rendimento máximo com 37,2 anos de experiência enquanto que com 12 anos de estudo o rendimento máximo é atingido com apenas 27,5 anos de experiência, verificamos assim uma diferença de quase 10 anos de experiência.

Entre os mercados de trabalho a diferença entre homens e mulheres é maior no mercado de trabalho informal. No mercado de trabalho formal o máximo rendimento, considerando 12 anos de estudo, é obtido com 34,2 e 30,0 anos de experiência, para homens e mulheres, respectivamente. Vemos então que a mulher atinge seu máximo rendimento com 4,2 anos de experiência a menos que o homem. No mercado de trabalho informal o rendimento máximo é obtido com 42,2 e 27,5 anos de experiência, para homens e mulheres respectivamente, levando em consideração 12 anos de estudo para ambos. Deste modo observa-se que o homem atinge o rendimento máximo com 14,7 anos de experiência a mais que a mulher.

Kassouf (1997) calculou o número de anos de experiência no qual homens e mulheres atingem o máximo rendimento nos dois setores, formal e informal. Os resultados por ela encontrados indicam que à medida que aumenta os anos de estudo, o número de anos de experiência no qual os indivíduos atingem o máximo rendimento decresce. Este resultado é verificado nos setores formal e informal, e para homens e mulheres. No mercado de trabalho formal os resultados encontrados por Kassouf diferem ligeiramente daqueles por nós encontrados. Os homens atingem o máximo rendimento com 35,5 (com 4 anos de estudo), 32,9 (com 8 anos de estudo) e 30,4 (com 12 anos de estudo) anos de experiência. As mulheres alcançam os maiores rendimentos com 35,2,31,9, e 28,6 anos de experiência com 4,8 e 12 anos de estudo respectivamente. Observa-se então que o número de anos de experiência com que os indivíduos atingem o máximo rendimento é ligeiramente inferior àquele encontrado neste trabalho em todos os níveis de escolaridade no setor formal. 
No setor informal os resultados encontrados por Kassouf (1997) são bastante diferentes daqueles aqui encontrados. Os homens atingem o máximo rendimento com 32,4,31,1, e 29,9 anos de experiência, com 4, 8 e 12 anos de estudo respectivamente. As mulheres atingem o máximo rendimento com 34,1, 32,2 e 30,3 anos de experiência a 4, 8 e 12 anos de estudo, respectivamente. Nota-se então que o número de anos de experiência no qual homens atingem o máximo rendimento no mercado de trabalho informal, encontrados no presente estudo, é significativamente superior aos resultados apresentados por Kassouf.

\subsection{O efeito da discriminação por gênero sobre os rendimentos}

Para medir a composição dos diferenciais de rendimento por gênero, ou seja, verificar a parte do diferencial nos rendimentos derivada de variações nas características produtivas individuais e a parte referente ao efeito da discriminação, utilizou-se o modelo econométrico desenvolvido por Blinder (1973) e Oaxaca (1973), utilizado mais recentemente por Brown, Moon e Zoloth (1980). Calculou-se os diferenciais de rendimento entre homens e mulheres nos segmentos formal e informal do mercado de trabalho e verificou-se o percentual devido à discriminação e a parte devida à diferenças nas características produtivas ${ }^{20}$. O método consiste em obter o rendimento estimado da mulher, utilizando-se as suas próprias características produtivas (médias Tabela 5) mas a estrutura dos homens (coeficientes estimados na equação de rendimentos - Tabela 11 ).

A Tabela 16 mostra a média dos rendimentos para homens e mulheres nos mercados de trabalho formal e informal e, os resultados obtidos para o rendimento estimado da mulher nos dois mercados ${ }^{21}$. No mercado de trabalho formal a média do rendimento do homem é 0,89 e da mulher 0,64 , isto é, a mulher recebe $22 \%$

\footnotetext{
${ }^{20}$ Nesta seção e na próxima, não faremos análise para os empregadores devido à grande parte dos coeficientes das equações estimadas para estes trabalhadores terem resultado em não significativos.

${ }^{21}$ os valores estão em logaritmo neperiano.
} 
menos que o homem. Observa-se neste mercado que se as mulheres tivessem a mesma estrutura dos homens, seus rendimentos aumentariam para 1,03, o que significa aumento de aproximadamente $47 \%$, atingindo, assim, rendimento superior ao do homem em aproximadamente $15 \% \%^{22}$. Assim, dado que a média do rendimento hipotético estimado para a mulher é superior à média do rendimento do homem, conclui-se que no mercado de trabalho formal os diferenciais de salário entre homem e mulher são inteiramente devido à discriminação.

Como foi explicado na seção 3.2.1, após calcular a média do rendimento estimado para as mulheres, o diferencial de rendimentos que permanecer entre o rendimento médio do homem e o rendimento médio estimado da mulher é atribuído às diferenças nas características produtivas dos dois grupos. Esta porção é freqüentemente descrita como "explicada". O aumento no rendimento médio das mulheres em relação à média do rendimento dos homens reflete a porção "inexplicada" ou "injustificada" dos diferenciais de rendimentos, ou seja, é a porção atribuída à discriminação. Como no mercado de trabalho formal o aumento do rendimento médio das mulheres (rendimento estimado) tornou o rendimento potencial das mulheres maior que o rendimento médio dos homens, todo o diferencial nos rendimentos é explicado pela discriminação.

Tabela 16. Média dos logaritmos dos rendimentos-hora observados para homens e mulheres e estimados para mulheres, em reais de 1995.

\begin{tabular}{lccc}
\hline & $\begin{array}{c}\text { Média dos rendimentos } \\
\text { dos homens (observado)* }\end{array}$ & $\begin{array}{c}\text { Média dos rendimentos das } \\
\text { mulheres (observado)* }\end{array}$ & $\begin{array}{c}\text { Média do } \\
\text { rendimento estimado } \\
\text { para as mulheres** }\end{array}$ \\
\hline M. T. formal & 0,89 & 0,64 & 1,03 \\
M. T. informal & 0,48 & 0,16 & 0,47 \\
\hline
\end{tabular}

* estes valores foram retirados da Tabela 5 .

** o rendimento médio hipotético estimado para a mulher foi calculado a partir das médias das mulheres, coluna 7 e 9 (Tabela 5), para os mercado de trabalho formal e informal, respectivamente e, dos coeficientes estimados para os homens, coluna 1 (mercado de trabalho formal) e 2 (mercado de trabalho informal) da Tabela 11.

\footnotetext{
${ }^{22}$ Para obter a porcentagem de $15 \%$ foi calculado: $1-\exp (1,03-0,89)=0,15$
} 
A mesma análise pode ser feita para o mercado de trabalho informal, onde a média do rendimento do homem e da mulher são 0,48 e 0,16, respectivamente, isto é, a mulher recebe $27 \%$ menos que o homem. Observa-se neste mercado que o rendimento estimado da mulher é de 0,47, com aumento de aproximadamente $36 \%$. Nota-se então que neste mercado o rendimento potencial da mulher não é maior que o rendimento médio do homem. Assim, as diferenças nas características individuais explicam 3\% do diferencial nos rendimentos, o restante (97\%) sendo determinado pela discriminação ${ }^{23}$.

Com base nessas análises pode-se concluir que a discriminação salarial por gênero ocorre em grandes proporções nos 2 mercados de trabalho, formal e informal, sendo maior a discriminação no mercado de trabalho formal. Kassouf (1997) também constatou a existência de discriminação salarial por gênero em grandes proporções nos 2 setores da economia. Entretanto, seus resultados mostraram que a discriminação é maior no setor informal que no setor formal, resultado este contrário ao obtido no presente estudo.

Kassouf verificou que no setor informal a mulher recebe $27 \%$ menos que o homem. O estudo demonstrou que na ausência de discriminação as mulheres receberiam $26 \%$ a mais que os homens. No setor informal o salário das mulheres é $23 \%$ inferior ao salário dos homens. Entretanto, na ausência de discriminação o salário das mulheres seria $67 \%$ maior que o dos homens.

Barros, Machado e Mendonça (1997), a partir de dados de São Paulo retirados da (Pesquisa Mensal do Emprego) PME, constataram que o salário médio das mulheres era cerca de $52 \%$ do salário dos homens em 1983 e cerca de $63 \%$ em 1993. Tomando uma subamostra de trabalhadores com baixo nível de escolaridade (somente trabalhadores com 4 anos de estudo), verificaram que o salário das mulheres era apenas 46\% do salário dos homens em 1983 e 52\% em 1993. Estes resultados

\footnotetext{
${ }^{23}$ Para obter a porcentagem de $3 \%$ foi calculado: $(0,48-0,47) /(0,48-0,16)=0,03$.
} 
indicam que o hiato salarial na subamostra é cerca de 5 a $10 \%$ mais elevado. Observaram também que um terço dos diferenciais de rendimento por gênero entre trabalhadores com mesma idade e nível educacional, pode ser explicado por diferenças em inserção ocupacional. Eles mostraram que as ocupações das mulheres não apenas são diferentes das ocupações dos homens como também piores, o que também pode ser uma forma de discriminação.

Brown, Moon e Zoloth (1980), usando dados de 1966 para homens e de 1971 para as mulheres americanas (eles assumiram que a estrutura ocupacional dos homens não mudou entre 1966 e 1971), retirados da "National Longitudinal Survey" (NLS), pesquisa realizada nos Estados Unidos, concluíram que do diferencial de renda existente entre homens e mulheres, 14 a $17 \%$ é explicado pelas diferenças nas características individuais entre os dois grupos, e o restante é discriminação.

Tiefenthaler (1994) concluiu que os diferenciais de rendimentos do trabalho entre homens e mulheres brasileiros estão mais fortemente relacionados à discriminação que à efetiva capacidade de trabalho das mulheres. Nos segmentos formal e conta própria entre 81 e $89 \%$ dos diferenciais de salários é atribuído à discriminação, enquanto no setor informal (onde Tiefenthaler considerou apenas trabalhadores que não possuem carteira de trabalho assinada) 72 e $75 \%$ do diferencial é devido à discriminação.

\subsection{O efeito da segmentação por mercado de trabalho, formal e informal, sobre os rendimentos}

Para medir a composição do diferencial de rendimentos por mercado de trabalho, ou seja, para calcular a parte do diferencial de rendimentos derivada de variações nas características produtivas individuais e a parte devida ao fato dos trabalhadores participarem de mercados de trabalho diferentes, utilizou-se o mesmo 
procedimento descrito na seção anterior. Calculou-se os diferenciais de rendimento entre os 2 mercados de trabalho, para homens e mulheres, e verificou-se qual a parte do diferencial de rendimentos devida à segmentação e a parte devida às diferenças na média das características produtivas dos trabalhadores em cada segmento do mercado de trabalho.

Os resultados obtidos estão apresentados na Tabela 17, na qual estão colocadas informações do rendimento médio nos mercados formal e informal e o rendimento médio estimado para o mercado informal, para homens e mulheres.

Tabela 17. Média dos logaritmos dos rendimentos-hora observados nos mercados formal e informal e estimados para o mercado informal, em reais de 1995.

\begin{tabular}{lccc}
\hline & $\begin{array}{c}\text { Média dos rendimentos } \\
\text { observados no mercado } \\
\text { formal }\end{array}$ & $\begin{array}{c}\text { Média dos rendimentos } \\
\text { observados no mercado } \\
\text { informal }\end{array}$ & $\begin{array}{c}\text { Rendimentos estimados } \\
\text { para o mercado informal }\end{array}$ \\
\hline Homem & 0,89 & 0,48 & 0,71 \\
Mulher & 0,64 & 0,16 & 0,04 \\
\hline
\end{tabular}

Os rendimentos auferidos pelos homens nos mercados formal e informal são respectivamente 0,89 e 0,48 . Observa-se para os homens que se os trabalhadores informais tivessem a mesma estrutura (coeficientes estimados nas equações de rendimentos) dos trabalhadores formais seus rendimentos aumentariam em aproximadamente $20 \%$. Este aumento indica que $44 \%$ do diferencial de rendimento é explicado pelas diferenças nas características produtivas individuais entre os trabalhadores dos dois segmentos de mercado de trabalho, o restante do diferencial (56\%) nos rendimentos é devido à segmentação.

Se as mulheres trabalhadoras no mercado de trabalho informal tivessem a mesma estrutura (coeficientes estimados nas equações de rendimento) das trabalhadoras formais, seus rendimentos seriam aproximadamente $27 \%$ do rendimento real obtido no mercado de trabalho informal. Este resultado indica que o diferencial de rendimentos entre as mulheres nos dois segmentos de mercado de trabalho é derivado 
das diferenças nas características produtivas individuais, isto é, não existe segmentação no mercado de trabalho. Kassouf (1997) concluiu que existe segmentação entre os mercados de trabalho formal e informal, sendo $80 \%$ das diferenças salariais observadas entre os mercados de trabalho atribuídas às diferenças nas características produtivas dos trabalhadores.

Tomando como base de referência os resultados obtidos pode-se concluir que não existe segmentação no mercado de trabalho para as mulheres. No entanto para os homens o grau de segmentação é expressivo. Uma grande parcela das diferenças salariais entre os dois segmentos de trabalho são as características produtivas individuais dos trabalhadores. Observando a Tabela 5 nota-se que o nível de escolaridade é significativamente menor para homens e mulheres no mercado de trabalho informal, fator este que é muito importante na determinação dos salários. Pode-se ver também, na Tabela 6, que os trabalhadores informais concentram-se nas regiões menos desenvolvidas (Norte, Nordeste e Centro-Oeste) e, a Tabela 8 mostra que nestas mesmas regiões os rendimentos são muito inferiores aos registrados nas regiões desenvolvidas. Portanto, as diferenças nos rendimentos entre os dois mercados estão vinculadas às diferenças individuais, sendo que para os homens a maior parcela no diferencial de rendimentos é derivada da segmentação do mercado. Vale observar que os coeficientes de determinação encontrados nas equações de rendimentos variaram de 0,30 a 0,50 , indicando que parte substancial da variabilidade dos rendimentos não foi explicada pelas variáveis incluídas no modelo. Devido à falta de dados disponíveis variáveis importantes não foram incluídas no modelo, tais como: qualidade da escolaridade do indivíduo, background da família, variável que capte melhor os anos de experiência dos indivíduos, saúde, migração, etc.

Pero (1994) estudou o diferencial salarial entre os empregados com e sem carteira de trabalho no Brasil. Constatou que os empregados com contrato formal de trabalho recebem em média o dobro daqueles que não possuem vínculo empregatício formal. Entretanto, mostrou que pouco mais da metade desse diferencial 
pode ser explicado por diferenças entre trabalhadores com e sem carteira de trabalho no que diz respeito a características individuais e produtivas, tais como escolaridade, idade e região de residência. Verificou que os trabalhadores sem carteira de trabalho pertencentes ao mesmo grupo educacional e etário e mesma região metropolitana ganham um salário $45 \%$ menor do que aqueles que pertencem a este mesmo compartimento do mercado de trabalho, o que evidencia uma forte segmentação no mercado de trabalho metropolitano brasileiro.

Marcouiller et al. (1997) verificaram a existência de segmentação entre os setores formal e informal nas economias de El Salvador e Peru. A diferença salarial em El Salvador é substancial. O diferencial de salário total para a mulher em El Salvador é de 0,96 , sendo este valor o resultado da diferença do logaritmo do salário no setor formal e do salário no setor informal. Parte desta diferença pode ser explicada pelas diferenças intersetoriais na composição da indústria e nas características individuais médias dos trabalhadores, em torno de $60 \%$ do diferencial. O resto da diferença, é a diferença salarial não explicada, ou seja, é a diferença salarial devido a segmentação do mercado de trabalho. A média do logaritmo da taxa de salário dos homens em El Salvador no setor formal é 0,71 mais alto que a média do logaritmo da taxa do salário no setor informal. Parte desta diferença salarial, aproximadamente 50\%, pode ser explicada pelas diferenças das características pessoais observadas, a outra metade é devido à segmentação do mercado de trabalho.

Marcouiller et al. encontraram diferenças salariais relativamente maiores para a mulher peruana $(0,89)$, mas também bastante significativo para os homens $(0,50)$. Para as mulheres, as características pessoais explicam somente metade das diferenças salariais, e para os homens um quarto da diferença permanece inexplicada. 


\subsection{O efeito da discriminação racial sobre os rendimentos}

Para verificar a existência de discriminação salarial devido às diferenças de cor dos trabalhadores, equações de participação para homens e mulheres brancos, pardos e pretos; nos mercados de trabalho formal e informal e para empregadores; foram estimadas por máxima verossimilhança usando o modelo lógite multinomial. Com base nos coeficientes estimados nas equações de participação a variável lambda (inverso da razão de Mill) foi calculada e usada nas equações de rendimentos para se obter estimativas dos parâmetros consistentes, i.e., sem viés de seletividade amostral. As equações de rendimento para homens e mulheres brancos encontram-se em apêndice (Tabela A3), sendo que as demais não foram incluídas no texto, os resultados das equações de participação também não foram incluídas no texto.

A média e desvios padrões das variáveis para homens e mulheres brancos, pardos e pretos nos mercados de trabalho formal e informal, e para empregadores, utilizadas para estimar as equações de rendimentos estão apresentados nas Tabelas A1 e A2 em apêndice. Pode-se observar, a partir destas Tabelas, que as mulheres têm escolaridade em torno de $20 \%$ superior à dos homens, sendo que o menor diferencial de escolaridade entre esses dois grupos ocorre no mercado de trabalho informal. Os maiores níveis de escolaridade são de trabalhadores brancos empregadores e do mercado de trabalho formal, enquanto que os níveis mais baixos são de trabalhadores pretos do mercado de trabalho informal. Ademais, em todos os mercados de trabalho, a escolaridade média dos brancos é superior à dos pardos, sendo a desses superior à dos pretos.

Os diferenciais salariais entre trabalhadores pretos, pardos e brancos são bastante nítidos no Brasil. Os trabalhadores de cor recebem em torno de $50 \%$ do salário dos brancos. A Tabela 18 fornece o rendimento médio por hora trabalhada em cada mercado de trabalho, formal e informal, e para empregador. 
Observa-se que no mercado de trabalho informal os trabalhadores de cor recebem uma proporção menor do rendimento dos brancos do que no mercado de trabalho formal ou empregadores. Entretanto, o número de anos de escolaridade dos pretos é $30 \%$ e $40 \%$ inferior ao dos brancos no mercado de trabalho formal e informal, respectivamente, e dos pardos $20 \%$ e $30 \%$ inferior ao dos brancos nos respectivos mercados de trabalho, indicando que os diferenciais salariais podem refletir discriminação, mas também refletem diferenças nas características produtivas dos indivíduos. Logicamente, como coloca Barros e Mendonça (1996), os diferenciais de produtividade entre trabalhadores de diferentes raças podem ter origem na discriminação e desigualdade de oportunidades que ocorrem até mesmo antes do ingresso no mercado de trabalho.

Tabela 18. Rendimento médio por hora de trabalho, em reais de 1995, nos mercados de trabalho formal e informal, para empregadores e total.

\begin{tabular}{lcccccc}
\hline & \multicolumn{3}{c}{ Homens } & \multicolumn{3}{c}{ Mulheres } \\
\cline { 2 - 7 } & Branco & Pardo & Preto & Branca & Parda & Preta \\
\hline Formal & 4,73 & 2,69 & 2,44 & 3,43 & 2,11 & 1,79 \\
Informal & 3,65 & 1,88 & 1,62 & 2,53 & 1,36 & 1,35 \\
Empregador & 10,20 & 6,71 & 4,95 & 8,31 & 6,76 & 5,26 \\
Total & 4,85 & 2,47 & 2,13 & 3,25 & 1,77 & 1,58 \\
\hline
\end{tabular}

Para medir a composição dos diferenciais de rendimento por cor, ou seja, verificar a parte do diferencial nos rendimentos derivada de variações nas características produtivas individuais e a parte referente ao efeito da discriminação, são calculados os diferenciais de rendimento entre homens e mulheres brancos, pardos e pretos nos segmentos formal e informal do mercado de trabalho, verificando-se o percentual devido à discriminação e a parte devida à diferenças nas características produtivas $^{24}$. O método consiste em obter o rendimento estimado dos pardos e pretos, utilizando-se as suas próprias características produtivas (médias - Tabelas A1 e A2 em apêndice) mas a estrutura dos brancos (coeficientes estimados na equação de rendimentos - Tabela $A 3$ em apêndice).

${ }^{24}$ Nesta seção não faremos análise para os empregadores devido à grande parte dos coeficientes das equações estimadas para estes trabalhadores serem não significativos. 
A Tabela 19 mostra as médias dos logaritmos dos rendimentoshora dos homens brancos, pardos e pretos nos mercados formal e informal, e as médias dos rendimentos estimados para pardos e pretos. No mercado de trabalho formal o diferencial de rendimento entre homens brancos e pardos, por exemplo, é de 0,47 (1,07 0,60 ). Observa-se neste mercado que se os homens pardos tivessem a mesma estrutura dos homens brancos a média dos seus rendimentos seria de 0,72 , e a diferença de rendimentos atribuída somente à diferença nas características deveria ser então de 0,35 $(1,07-0,72)$. Com base nesses valores obtém-se que $74 \%(0,35 / 0,47)$ do diferencial de rendimentos é devido às características dos indivíduos (escolaridade, experiência, etc.) e o restante, $26 \%$, à discriminação. A mesma análise foi realizada para homens pretos com relação aos brancos, e mulheres pardas e pretas com relação as brancas nos mercados de trabalho formal e informal. Os resultados encontram-se nas Tabelas 19 e 20.

Tabela 19. Média dos logaritmos dos rendimentos-hora observados para homens e mulheres (brancos, pardos e pretos) e estimados para homens e mulheres (pardos e pretos), em reais de 1995.

\begin{tabular}{|c|c|c|c|c|c|c|c|c|c|c|}
\hline \multirow{3}{*}{$\begin{array}{l}\text { Mercado } \\
\text { de trabalho }\end{array}$} & \multicolumn{5}{|c|}{ Homens } & \multicolumn{5}{|c|}{ Mulheres } \\
\hline & \multicolumn{3}{|c|}{$\begin{array}{c}\text { Média dos Rendimentos } \\
\text { Observados }\end{array}$} & \multicolumn{2}{|c|}{$\begin{array}{l}\text { Rendimentos } \\
\text { Estimados }\end{array}$} & \multicolumn{3}{|c|}{$\begin{array}{c}\text { Média dos Rendimentos } \\
\text { Observados }\end{array}$} & \multicolumn{2}{|c|}{$\begin{array}{c}\text { Rendimentos } \\
\text { Estimados }\end{array}$} \\
\hline & branco & pardo & preto & pardo & preto & branco & pardo & preto & pardo & preto \\
\hline Formal & 1,07 & 0,60 & 0,53 & 0,72 & 0,65 & 0,81 & 0,35 & 0,25 & 0,47 & 0,31 \\
\hline Informal & 0,75 & 0,16 & 0,14 & 0,26 & 0,38 & 0,39 & $-0,12$ & $-0,08$ & 0,04 & 0,09 \\
\hline
\end{tabular}

Tabela 20. Decomposição dos diferenciais de rendimentos devido as características produtivas e discriminação racial, em porcentagem.

\begin{tabular}{lcccc|cccc}
\hline \multirow{2}{*}{$\begin{array}{l}\text { Mercado } \\
\text { de trabalho }\end{array}$} & \multicolumn{2}{c}{ Homem Pardo } & \multicolumn{2}{c|}{ Homem Preto } & \multicolumn{2}{c}{ Mulher Parda } & \multicolumn{2}{c}{ Mulher Preta } \\
\cline { 2 - 9 } & Caracter & Discrim & Caracter & Discrim & Caracter & Discrim & Caracter & Discrim \\
\hline Formal & 74 & 26 & 78 & 22 & 74 & 26 & 89 & 11 \\
Informal & 83 & 17 & 61 & 39 & 69 & 31 & 64 & 36 \\
\hline
\end{tabular}

Observa-se que os pretos (homens e mulheres) e as mulheres pardas sofrem mais discriminação no mercado de trabalho informal do que no formal, enquanto que os homens pardos sofrem mais discriminação no mercado de trabalho formal do que no informal. Em geral, a maior porcentagem do diferencial de 
rendimentos é explicada pelas diferenças nas características dos indivíduos e não pela discriminação, mas a porcentagem devido à discriminação também é bastante alta. A menor porcentagem do diferencial de rendimentos devido à discriminação foi para mulheres pretas no mercado de trabalho formal (11\%), enquanto que a maior foi para os homens pretos no mercado informal (39\%). Ademais, constatou-se que as mulheres pardas no mercado de trabalho informal sofrem mais discriminação do que os homens da mesma cor, enquanto que as mulheres pretas sofrem menos discriminação do que os homens pretos nos dois mercados de trabalho.

É interessante observar que no mercado de trabalho formal, os pardos sofrem mais discriminação com relação aos brancos do que os pretos, enquanto que no mercado de trabalho informal os pretos são mais discriminados do que os pardos.

Trabalhos realizados com base em dados de trabalhadores americanos chegaram a taxas elevadas de discriminação. Corcoran e Duncan (1979) incorporando nas equações de rendimentos variáveis como: ausência ao trabalho por problemas de saúde, interrupção no período de treinamento no trabalho, restrições devido a localização e número de horas de trabalho, além de escolaridade e experiência, concluíram que $47 \%$ do diferencial de rendimentos entre homens brancos e pretos era devido a discriminação.

Valle Silva (1993) utilizando a PNAD de 1988 observou que o diferencial salarial entre os chefes dos domicílios brancos e pretos devido a discriminação era próximo de $46 \%$, enquanto entre brancos e pardos era de $32 \%$. Lovell (1992), utilizando o censo de 1980 , observou que $16 \%$ e $32 \%$ do diferencial salarial eram resultados de discriminação entre brancos e afro-brasileiros, para mulheres e homens, respectivamente. Lovell também concluiu que os homens eram mais discriminados do que as mulheres no mercado de trabalho, o que está próximo ao resultado obtido no presente estudo. 


\section{SÍNTESE DOS PRINCIPAIS RESULTADOS OBTIDOS NAS EQUAÇÕES DE PARTICIPAÇÃO E DE RENDIMENTOS}

As equações de participação foram estimadas por máxima verossimilhança usando o modelo multinomial lógite, onde a variável dependente toma o valor zero se a pessoa não trabalha, 1 se trabalha no setor formal, 2 trabalha no setor informal e 3 é empregador, para homens e mulheres residindo no setor urbano com idade entre 25 e 65 anos. Os resultados mostraram que escolaridade, idade, número e idade das crianças no domicílio, raça, região onde vive e renda não salarial afetam a participação do indivíduo no mercado de trabalho.

A presença de filhos pequenos na família influencia positivamente a participação do pai no mercado de trabalho, pois a presença de filhos aumenta os gastos, o que leva à necessidade de aumento da renda familiar. Para a mulher, a presença de filhos tem forte efeito negativo em sua participação no mercado de trabalho, com exceção da mulher empregada no setor informal que tenha filho de 3 a 5 anos de idade, os quais não exigem tanto tempo de suas mães quanto os filhos com menos de 2 anos de idade. Pode-se concluir que no mercado informal as mulheres podem conciliar a tarefa de ser mãe e trabalhar. Observou-se que a menor participação da mulher no mercado de trabalho devido a presença de filhos muito novos é maior no mercado de trabalho formal. A presença de crianças com idade entre 6 e 12 anos diminui a participação dos homens nos três mercados de trabalho, mas considerando que no Brasil a proporção de trabalhadores infantis no total de trabalhadores é alta, pode-se afirmar que este resultado. 
reflete a realidade do mercado de trabalho brasileiro, onde uma grande parte das crianças, assim que possibilitadas de trabalhar, participam do mercado de trabalho para complementar a renda da família. A presença desses filhos diminui a probabilidade da mulher ter emprego formal e aumenta a probabilidade de participação das mulheres no mercado informal.

Filhas e filhos maiores de 12 anos afetam negativamente a participação dos pais nos três mercados de trabalho. Os resultados encontrados nas equações dos homens indicaram que os filhos entram no mercado de trabalho complementando a renda familiar ou então tornando-se independentes financeiramente da renda do pai. As equações de participação estimadas para as mulheres indicaram que os (as) filhos (as) substituem totalmente o ingresso das mães no mercado de trabalho, gerando renda para a família de modo a permitir que elas permaneçam em casa, ou, então, simplesmente entram no mercado de trabalho para complementar a renda familiar.

A participação de indivíduos classificados como filho na família é mais intensa no mercado de trabalho informal quando comparada com a participação dos indivíduos chefes neste mesmo mercado. O contrário é observado para empregadores em que a participação dos chefes é maior neste segmento do que a participação dos indivíduos classificados como filho. A participação da mulher classificada como filha é menor que a participação do homem (filho), tanto no mercado de trabalho formal quanto no informal. A posição da mulher na família como cônjuge afeta negativamente a sua participação no mercado de trabalho, o que é bastante comum na sociedade brasileira. Com efeito, uma grande parte das mulheres brasileiras casadas são financeiramente dependentes de seus maridos.

O fato do homem ser casado afeta positivamente a sua participação no mercado de trabalho, enquanto que para as mulheres o efeito observado foi contrário. Estes resultados são consistentes pois na sociedade brasileira a responsabilidade pelas despesas da família é normalmente do homem. Assim sendo, o 
resultado obtido mostra que os homens casados têm maior probabilidade de participar do mercado de trabalhodo que os homens solteiros. Decorrente do que foi dito, para a mulher a situação é inversa à do homem, ou seja, a probabilidade da mulher casada participar do mercado de trabalho é menor que da mulher solteira. Este resultado está associado ao fato de grande parte das mulheres casadas ser dependente de seus maridos.

A experiência mostrou-se muito importante como fator determinante da participação no mercado de trabalho. Os resultados sugerem que à medida que o indivíduo ganha experiência, sua probabilidade de participar do mercado de trabalho aumenta até atingir um ponto onde o capital humano começa a se depreciar. A partir deste ponto, a probabilidade de participação diminui, pois a partir de uma determinada idade a produtividade dos indivíduos declina. Os resultados mostraram também que a experiência tem maior efeito na participação das mulheres do que dos homens nos mercados formal e informal.

A escolaridade tem um efeito muito forte sobre a participação do homem e da mulher na força de trabalho. Tal efeito é mais forte para os indivíduos que trabalham no mercado formal e para os empregadores. Entretanto, pode-se observar que o aumento de 1 ano de estudo decresce em 2,8 pontos percentuais a probabilidade de participação dos homens no mercado informal, o que pode ser explicado pelo fato do aumento da escolaridade aumentar a probabilidade dos indivíduos conseguirem emprego formal.

Os resultados obtidos para o termo de interação entre as variáveis experiência e escolaridade indicaram que o efeito da escolaridade (experiência) diminui quando os anos de experiência (escolaridade) aumentam, ou seja, a importância do nível de escolaridade (experiência) para obtenção de emprego torna-se menor quando o indivíduo tem uma grande experiência (escolaridade).

Os resultados obtidos para as variáveis representando a riqueza dos indivíduos, posse de casa própria e renda não salarial, mostraram uma relação 
inversa entre nível de riqueza e participação no mercado de trabalho, sendo que o efeito negativo observado é bastante significativo para os 3 segmentos de trabalhadores.

Nas Regiões Sul, Sudeste e Centro-Oeste os indivíduos (homem e mulher) têm menor probabilidade de participar do mercado de trabalho informal do que os indivíduos residentes na Região Nordeste. As oportunidades de emprego no mercado de trabalho formal são maiores nas regiões mais desenvolvidas do país, enquanto as oportunidades de emprego no mercado de trabalho informal são maiores nas regiões menos desenvolvidas.

Equações de rendimento foram estimadas por mínimos quadrados ponderados, tendo sido feita a correção do viés de seletividade amostral. Com base nos coeficientes estimados nas equações de participação no mercado de trabalho, a variável lambda (inverso da razão de Mill) foi calculada e usada para estimar as equações de rendimentos nos 3 mercados de trabalho para homens e mulheres, de modo a obter estimativas consistentes dos parâmetros, uma vez que só indivíduos participando do mercado de trabalho possuem salários. A variável dependente usada na regressão foi o logaritmo neperiano do salário hora de cada indivíduo participando do mercado de trabalho. Os resultados indicam que escolaridade, experiência, cor do indivíduo, região e setor de atividade produtiva onde o indivíduo trabalha, e sua situação sindical são fatores que afetam os rendimentos.

A variável LAMBDA apresentou coeficientes altamente significativos, indicando que sua inclusão no modelo era necessária para evitar problemas de tendenciosidade nas estimativas dos parâmetros causados pela seletividade amostral.

Os resultados encontrados tiveram os sinais corretos e alta significância estatística para as equações dos trabalhadores formais e informais, tanto para homens quanto para mulheres. Entretanto, os resultados obtidos nas duas equações dos empregadores foram ruins, com poucos coeficientes estatisticamente significativos. 
Fazer inferências a partir dos coeficientes estimados poderia resultar em conclusões erradas. Assim, na discussão dos resultados apenas as equações estimadas para os trabalhadores formais e informais foram consideradas.

As equações estimadas mostraram que a escolaridade dos trabalhadores é determinante crucial de seus rendimentos. Os resultados indicam que o estudo é mais valorizado no mercado de trabalho formal.

Encontrou-se uma função de rendimentos com curva parabólica para a experiência, como sugerido pela teoria do capital humano, indicando que os rendimentos alcançam um valor máximo em algum ponto da vida do indivíduo e, a partir daí começa o processo de depreciação do capital humano, o que se reflete na produtividade dos trabalhadores que começa a declinar e consequentemente o nível de salário cai a partir deste ponto.

Constatou-se que os negros recebem salários menores que os brancos e pardos, o que sugere a existência de discriminação racial. Observou-se ainda que os brancos não estão em situação favorável apenas em relação aos negros, mas também em relação aos pardos e, a diferença salarial é maior entre brancos e negros que entre pardos e negros. Ademais, a diferença salarial é maior no mercado de trabalho informal, o que pode ser explicado pelo fato dos trabalhadores negros que conseguem emprego no mercado formal serem os mais qualificados, com maior nível de escolaridade e experiência, e possuírem contrato formal de trabalho que os protegem contra a discriminação. Verificou-se ainda que a diferença salarial é maior entre as mulheres que entre os homens.

As equações estimadas evidenciam diferenças regionais nos salários de todos os trabalhadores. Homens e mulheres trabalhando na Região Nordeste recebem salários menores do que trabalhadores residentes nas demais regiões brasileiras nos dois mercados de trabalho, formal e informal. Verificou-se que os trabalhadores formais obtêm salários mais altos nas regiões mais desenvolvidas, enquanto os 
trabalhadores informais (excluindo-se a Região Nordeste) são melhor remunerados nas regiões menos desenvolvidas, exceto as mulheres com empregos informais, que obtêm os rendimentos mais elevados na Região Sudeste. Possivelmente a mulher com emprego informal na região mais desenvolvida do país não possui condições de trabalho tão precárias quanto os homens dessa região. Daí, é possível inferir-se que as diferenças salariais entre os mercados de trabalho formal e informal são maiores nas regiões mais desenvolvidas. Concluímos, assim, que o diferencial de salário entre os dois mercados de trabalho está diretamente relacionado com o grau de desenvolvimento das regiões, ou seja, em regiões mais desenvolvidas o diferencial de salário é maior que o diferencial de salário verificado nas regiões menos desenvolvidas.

No setor primário os trabalhadores recebem remuneração menor que nos dois outros setores. Observou-se ainda que a remuneração dos trabalhadores formais é maior no setor secundário do que no setor terciário enquanto a remuneração dos trabalhadores informais é ligeiramente superior no setor terciário. No setor terciário, quase metade dos trabalhadores são informais, enquanto no setor secundário os trabalhadores são predominantemente formais - $60 \%$ estão no mercado de trabalho formal e apenas $35 \%$ estão no mercado informal. A maior concentração de trabalhadores informais no setor terciário talvez não seja explicada apenas pelo fato deste setor ofertar maior quantidade de empregos com contratos informais de trabalho. Uma possível explicação seria a de que os trabalhadores encontram melhor remuneração no setor terciário.

A filiação do trabalhador a algum sindicato é um fator muito importante na determinação dos rendimentos. Os resultados indicam que os trabalhadores sindicalizados estão em melhores condições de trabalho que os demais, sendo ainda melhor remunerados. Os trabalhadores filiados a algum sindicato recebem salários maiores pois o movimento dos sindicatos dos trabalhadores é no sentido de se fazer cumprir as leis e regulamentações que protegem os trabalhadores. 


\section{CONCLUSÕES}

Constatou-se que $45 \%$ da força de trabalho brasileira ocupada é formada por trabalhadores informais e, a partir da revisão de literatura, observou-se que a participação desses trabalhadores têm crescido de forma significativa desde início da década de 80. Não existe nada que evidencie a reversão deste quadro, logo, a visão de que o setor com relações informais de trabalho é gerador de empregos aponta para duas questões fundamentais. Por um lado, o setor apresenta a capacidade de absorver contigentes de mão-de-obra não empregada no mercado de trabalho formal e reduzir a taxa de desemprego. Por outro lado, a situação deficitária da previdência social pode ser explicada pelo fato do número de trabalhadores informais ser maior que o número de trabalhadores com carteira registrada que contribuem para o sistema previdenciário. Este problema pode se agravar mais ainda, pois enquanto a população empregada no mercado de trabalho informal cresce, registra-se um progressivo envelhecimento da população que contribui para o INSS que poderá aposentar-se dentro de poucos anos, com possível agravamento do déficit da previdência.

Muitos estudiosos do mercado de trabalho brasileiro defendem a hipótese de que a legislação previdenciária e mesmo a trabalhista favorece a contratação de empregados sem contrato formal de trabalho. Devido à inflexibilidade dessas leis há um aumento nos custos de se contratar empregados com contrato formal. De fato, dados do IBGE permitem observar que o crescimento da economia informal intensificou-se após a promulgação da constituição de 1988, que aumentou os benefícios sociais 
onerando o custo trabalhista para as empresas. No entanto, o processo de informalização acelerou-se, também, devido ao aumento do desemprego ligado aos processos tecnológicos e à maior produtividade. Uma legislação mais flexível poderia evitar o aumento do número de trabalhadores na informalidade. A longo prazo, é necessário terse em conta que a informalidade deixa sem proteção social os trabalhadores. Vale ressaltar que não são todos os trabalhadores que têm consciência dessa realidade.

Com base nas equações de rendimentos estimadas foram calculados os retornos à experiência e à escolaridade. Os retornos à experiência são positivos e declinantes com aumentos no número de anos de experiência e de escolaridade, exceto para os homens no mercado de trabalho informal, cujas taxas de retorno à experiência crescem com o nível de escolaridade. Além disso, verificou-se, para os homens, retornos à experiência maiores no mercado de trabalho informal e; para as mulheres retornos maiores no mercado de trabalho formal.

Encontraram-se retornos à escolaridade variando de 4,58\%, para homens no mercado informal, a $14,61 \%$, para o homem no mercado formal. Para as mulheres, as taxas de retorno à escolaridade variam de $8,22 \%$, no mercado informal, a $17,71 \%$, no mercado formal. Nesta pesquisa, os retornos à escolaridade são significativamente maiores do que aqueles encontrados por outros pesquisadores brasileiros. Entretanto, os resultados aqui encontrados são coerentes, considerando que os dados em análise são bastante recentes (1995), enquanto a maioria dos estudos anteriores trabalhou com dados da década de 80 , período de grandes mudanças na economia brasileira. Dentre elas destaca-se a abertura da economia, que forçou as empresas a buscarem maior competitividade. Sabendo-se que o investimento em capital humano é um dos principais fatores na busca de competitividade, pode-se deduzir que, com a abertura da economia as empresas passaram a valorizar mais a mão-de-obra qualificada. Daí, o substancial aumento nos retornos à escolaridade. 
Forçadas à modernização acelerada do início da década, as empresas brasileiras mudaram a maneira de produzir, de vender e de empregar. Elas finalmente estão se convencendo de que as taxas de retorno dos investimentos em capital humano tendem a ser maiores do que em qualquer outro tipo de investimento; assim, os novos requisitos para novas contratações por parte dos empregadores têm maiores exigências quanto à escolaridade e ao conhecimento dos processos produtivos. O perfil dos trabalhadores que mantiveram seus empregos deu uma pista da seleção processada pelo mercado com base na qualificação. As transformações econômicas desta década colocaram gradualmente mais exigências de instrução, experiência e preparo tanto dos empregados quanto dos candidatos a um emprego.

Os retornos à escolaridade são positivos e declinam com aumentos nos anos de experiência. Ademais, os retornos à escolaridade são muito maiores do que os retornos à experiência, exceto para homens no mercado de trabalho informal. Os retornos à escolaridade obtidos no mercado de trabalho formal são aproximadamente 3 vezes e 2 vezes maiores do que os retornos obtidos no mercado informal para homem e mulher, respectivamente. Constatou-se que os retornos à escolaridade são maiores para as mulheres nos dois mercados de trabalho.

Concluiu-se que com exceção do homem no mercado de trabalho informal, o número de anos de experiência no qual os rendimentos atingem o valor máximo decresce com o aumento nos anos de estudo. A mulher atinge seu rendimento máximo com menor número de anos de experiência do que o homem, sendo que esta diferença é maior em níveis mais elevados de escolaridade. Entre os mercados de trabalho, a diferença entre homens e mulheres é maior no mercado de trabalho informal.

No que diz respeito à desigualdade salarial vinculada à discriminação por gênero, verificou-se que se as mulheres tivessem a mesma estrutura dos homens, no mercado de trabalho formal, seus rendimentos aumentariam em aproximadamente 47\%, atingindo rendimento superior ao do homem em 
aproximadamente $15 \%$. Desta forma concluiu-se que no mercado de trabalho formal os diferenciais de salário entre homem e mulher são explicados somente pela discriminação. No mercado de trabalho informal, as diferenças nas característica individuais explicam $3 \%$ do diferencial nos rendimentos, e o restante (97\%) é determinado pela discriminação. Com base nessas análises concluiu-se que a discriminação salarial por gênero ocorre em grandes proporções nos formal e informal, sendo maior no mercado de trabalho formal.

De acordo como o estudo "Mulheres Latino Americanas em Dados" divulgado pelo Fundo das Nações Unidas para o Desenvolvimento da Mulher (Unifem), a participação das mulheres brasileiras no mercado de trabalho aumentou $40 \%$ na década de 90. Dentre os fatores que favoreceram o incremento da participação feminina na força de trabalho destacam-se a queda da taxa de fecundidade e o aumento do nível de instrução das mulheres, fatores que proporcionam maiores condições de inserção e competitividade das mulheres no mercado de trabalho. Nos dias atuais o nível de instrução da população feminina ocupada ultrapassa o nível de instrução da população masculina ocupada em aproximadamente $20 \%$. Entretanto, os resultados deste trabalho indicam que o aumento de sua participação no mercado de trabalho não foi acompanhada por condições igualitárias nos rendimentos em relação aos homens. No mercado de trabalho formal os rendimentos das mulheres correspondem em média a $74 \%$ do que recebem os homens. No mercado informal os rendimentos correspondem em média a apenas $71 \%$ dos rendimentos dos homens e as empregadoras recebem em média $84 \%$ dos rendimentos obtidos pelos homens empregadores.

Vários estudos, mostram que os diferenciais salariais por gênero no Brasil, estão fortemente relacionados com as diferenças de inserção ocupacional entre homens e mulheres. Barros et al. (1997) mostraram que as ocupações das mulheres não apenas são diferentes das ocupações dos homens como também piores, o que também pode ser uma forma de discriminação. Segundo esses autores, inserção ocupacional é um fator muito importante para explicar desigualdade nos rendimentos por gênero. A 
inserção ocupacional e o tratamento desigual de homens e mulheres no mercado de trabalho estão intimamente relacionados. Os homens ocupam com maior freqüência melhores posições na distribuição de rendimentos do que as mulheres. Barros et al. (1997) mostraram que 50\% das mulheres encontram-se em ocupações que cobrem menos de $5 \%$ da força de trabalho masculina e, da mesma forma $50 \%$ dos homens localizam-se em ocupações que cobrem menos de $5 \%$ da força de trabalho feminina.

As diferenças na inserção ocupacional entre homens e mulheres revelam a existência de um círculo vicioso para a força de trabalho feminina; menores oportunidades de acesso a bons cargos nas empresas, para os quais são oferecidos cursos de capacitação de recursos humanos, de modo que as mulheres têm menos oportunidades de acesso a treinamento/capacitação, o que leva à não ocupação de bons cargos nas empresas, que reflete rendimentos inferiores.

Neste contexto, tem-se uma situação onde políticas que visem amenizar a discriminação contra as mulheres são muito complexas e difíceis, pois tal situação é uma característica estrutural, sócio-econômica e cultural do Brasil. Em primeiro lugar, recomenda-se o planejamento de uma estratégia de marketing divulgando que a força de trabalho feminina é tão produtiva quanto a masculina. Entretanto, o problema da discriminação contra as mulheres pode estar vinculado à legislação trabalhista em vigor, a qual aumenta o custo de contratação da força de trabalho feminina. Os planejadores econômicos devem repensar esta lei e verificar até onde ela beneficia a mulher e onde começa a prejudicá-la.

"Para o assessor especial do Ministério do Trabalho Jorge Jatobá, esse fenômeno (altas taxas de desemprego entre as mulheres) pode ser explicado pelos efeitos da política macroeconômica, discriminação e proteção demasiada pela legislação... A discriminação ainda é presente no mercado de trabalho, apesar de ter sido reduzida. Por outro lado, na opinião de Jatobá, a Constituição de 88 ampliou alguns direitos para as mulheres, mas acabou restringindo a participação feminina no mercado. 
A licença-maternidade de 120 dias e a proibição de demissão da gestante desde a confirmação da gravidez até cinco meses depois do parto dificultam a contratação" (Emerick, 1997).

Outros fatores aumentam os custos de contratação da mão-deobra feminina, tais como: número maior de faltas das mulheres com relação aos homens, devido a doença ou qualquer outro problema com os filhos menores, ou queda de sua produtividade na presença de tais problemas. Assim, acredita-se que a discriminação contra as mulheres esteja fortemente relacionada à racionalidade econômica das empresas, buscando minimizar os custos de contratação de mão-de-obra e manter elevada a produtividade dos trabalhadores contratados. Deste modo, uma forma de diminuir a discriminação seria dar incentivos fiscais às empresas para a contratação de mulheres, tais como: diminuição dos encargos sociais incidentes sobre a folha de salários da mão-de-obra feminina, diminuição da carga tributária e maior facilidades de acesso ao crédito vinculando-o à proporção de mulheres empregadas na empresa.

Nesta pesquisa concluiu-se que não existe segmentação no mercado de trabalho para as mulheres e, para os homens o grau de segmentação é muito grande. Concluiu-se que um grande causador de diferenças salariais entre os dois segmentos de trabalho são as características produtivas individuais dos trabalhadores. Foi constatado que o nível de escolaridade é significativamente menor para homens e mulheres no mercado de trabalho informal, fator este que é muito importante na determinação dos salários, e também que os trabalhadores informais concentram-se nas regiões menos desenvolvidas (Norte, Nordeste e Centro-Oeste) onde os rendimentos são muito inferiores aos registrados nas regiões desenvolvidas.

As políticas que poderiam amenizar o problema dos diferenciais de rendimentos entre os mercados de trabalho formal e informal são essencialmente de longo prazo, as quais devem visar diminuir as disparidades regionais existentes no Brasil que é um fator determinante fundamental nas diferenças de rendimentos observados 
entre os mercados de trabalho, visto que os trabalhadores informais concentram-se nas regiões menos desenvolvidas e são nessas regiões onde os salários são menores.

A longo prazo vê-se como mecanismo mais eficaz para diminuir a desigualdade de rendimentos entre os dois mercados de trabalho a ampliação do conjunto de oportunidades da população empregada no mercado de trabalho informal elevar seu nível de qualificação. Ganhos de produtividade só serão obtidos se os trabalhadores elevarem seu nível de escolaridade. Neste estudo, a fonte principal de ganhos permanentes de eficiência e, consequentemente, de melhores rendimentos para os trabalhadores.

Cabe ao Estado proporcionar acesso ao ensino formal de qualidade às camadas da população desprovidas de recursos próprios. Hoje, a situação do ensino brasileiro é precária. A taxa de repetência é em média de $30 \%$ e apenas $60 \%$ dos indivíduos que ingressam na escola completam 8 anos de estudo e a falta de formação dos professores é um dos problemas mais sérios. "É imprescindível aumentar o acesso à escolaridade formal, entre os 10,3 milhões de jovens entre 15 e 17 anos, apenas $24 \%$ estão matriculados no ensino médio" (Silva, 1997).

Uma nova política educacional certamente teria reflexos na economia como um todo, gerando desenvolvimento econômico, e elevando a produtividade dos trabalhadores. Dados dos últimos anos (1990-1997) revelam que com o crescimento da atividade econômica quem mais teve ganhos salariais foram os trabalhadores informais, o que diminuiu sua desvantagem salarial em relação aos trabalhadores formais.

O fato do rendimento médio dos trabalhadores informais ser mais baixo pode ser também devido à proporção de trabalhadores informais ser relativamente mais baixa nos ramos de atividade com altos salários (indústria) e relativamente mais elevada nos ramos com baixos salários (serviços). Assim, grande parte do diferencial de rendimento é consequiência dos postos de trabalhos informais 
estarem super representados nos ramos de atividade que pagam baixos salários e devido a diferenças na estrutura ocupacional dos segmentos formais e informais da economia. Mais uma vez, essas diferenças na estrutura ocupacional dos segmentos de trabalho podem estar relacionadas à capacidade produtiva dos trabalhadores, ou seja, à sua qualificação. Assim, o governo tem que assumir seu papel no que diz respeito a investimentos em escolaridade, no sentido de melhorar a distribuição de renda e promover o desenvolvimento econômico do país. Este processo levará naturalmente a uma diminuição dos diferenciais de rendimentos existentes entre os mercados de trabalho formal e informal.

Constatou-se ainda que a principal causa das diferenças salariais entre os trabalhadores pardos e pretos com relação aos brancos é atribuída as suas características produtivas individuais. Entretanto, a porcentagem da diferença de rendimento devido à discriminação racial também é alta. Os trabalhadores pretos, homens e mulheres, assim como as mulheres pardas, sofreram maior discriminação salarial no mercado de trabalho informal (39\% para homens pretos, $36 \%$ para mulheres pretas e $31 \%$ para mulheres pardas), enquanto que a maior discriminação observada para os homens pardos foi no mercado de trabalho formal (26\%). Comparativamente, a menor taxa de discriminação foi observada para as mulheres pretas no mercado de trabalho formal (11\%), enquanto que a maior foi para os homens pretos do mercado de trabalho informal (39\%). Finalmente, observou-se que as mulheres pardas no mercado de trabalho informal sofrem mais discriminação do que os homens da mesma cor, enquanto que as mulheres pretas sofrem menos discriminação do que os homens pretos nos dois mercados de trabalho.

Os resultados mostraram a importância em se diferenciar os mercados de trabalho, uma vez que os pretos, apesar de sempre discriminados com relação aos brancos, serem menos discriminados do que os pardos no mercado de trabalho formal. Ademais, a discriminação racial observada no mercado de trabalho informal é maior do que no mercado de trabalho formal. 
Os resultados também mostraram a necessidade de se ter investimentos em escolaridade para que haja redução da desigualdade de renda no Brasil, principalmente para os pretos e pardos que atualmente têm nível de escolaridade em torno de $30 \%$ abaixo dos brancos. 


\section{REFERÊNCIAS BIBLIOGRÁFICAS}

BARROS, R. P de; MACHADO, A. F.; MENDONÇA, R. S. P. de. A desigualdade da pobreza: estratégias ocupacionais e diferenciais por gênero. Texto para discussão. IPEA, n. 453, jan. 1997.

BARROS, R. P. et al. Informal labor contracts a solution or a problem? Texto para discussão. IPEA, n. 291, 1992.

BARROS, R. P. ; R. MENDONÇA. Os Determinantes da Desigualdade no Brasil. A Economia Brasileira em Perspectiva. IPEA, Rio de Janeiro, v. 2, p. 421-473 1996.

BARROS, R. ; VARANDAS, S. A carteira de trabalho e as condições de trabalho e remuneração dos chefes de família no Brasil. Revista da Anpec, v. 10, n. 12, dez. 1987.

BARROS, R.; REIS, J. G. A.; RODRIGUEZ, J. S. Segmentação no mercado de trabalho: a carteira de trabalho na construção civil. Rio de Janeiro: IPEA, 1990.

BECKER, G. Investiment in human capital: a theoretical analyses. Journal of Political Economy, supplement, v. 70, n. 5, part 2, p. S9-S49, 1962.

BERNDT, E. R. The practice of econometrics classic and contemporary. Reading: Addison Wesley, 1991.

BROWN, R. S.; MOON, M.; ZOLOTH, B. S. Incorporating occupational attainment in studies of male-female earnings differentials. Journal of human resourses, v. 15, n. 1 , p. $3-28,1980$. 
CACCIAMALI, M. C. A expansão do mercado de trabalho não regulamentado e setor informal no Brasil. Estudos Econômicos, v. 19, n. esp., 1989a.

As Economias informal e submersa: conceitos e distribuição de renda. In: CAMARGO, J. M., GIAMBIAGI, F. (Orgs.). A distribuição de renda no Brasil. Rio de Janeiro: Paz e Terra, 1991.

A informalização recente do mercado de trabalho no Brasil. Literatura Econômica, 1989b.

. Emprego no Brasil durante a primeira metade da década de 80. In:

BARROS, R. P. DE; SEDLACEK, G. L. (Orgs.). Mercado de trabalho e distribuição de renda: uma coletânea. Rio de Janeiro: INPES/IPEA, 1989c (Série Monográfica, 35).

Relações entre desemprego aberto, subemprego, e o setor informal em uma economia de industrialização intermediária ao longo do ciclo econômico. In: ENCONTRO NACIONAL DE ECONOMIA, 12., Anais. São Paulo: ANPEC, 1984, v. 3, p. $937-967$.

. Um estudo sobre o setor informal urbano e formas de participação na produção. São Paulo, 1982. 234p. Tese (Doutorado) - Faculdade de Economia, Administração e Contabilidade da Universidade de São Paulo.

CACCIAMALI, M. C.; FERNANDES, R. Distribuição dos trabalhadores e diferenciais de salários entre o mercado de trabalho regulamentado e não regulamentado. Pesquișa e Planejamento Econômico, v. 23, n. 1, 1993. 
CAMARGO, J. M. Informalização e renda no mercado de trabalho. In: BARROS, R. P. DE; SEDLACEK, G. L., (Orgs.). Mercado de trabalho e distibuição de renda: uma coletânea. Rio de Janeiro: INPES/IPEA, 1989 (Série Monográfica, 35).

CORCORAN, M. e G. DUNCAN. Work history, labor force attachment, and earnings differences between the races and sexes. Journal of Human Resources, v. 14, n. 1, p. 3-20, 1979.

EMERICK, S. Emprego é mais difícil para mulher jovem. Folha de S. Paulo, São Paulo, 5 ago. 1997 p. 2-6.

FERNANDES, R. Contratos informais de trabalho: uma análise a partir da experiência brasileira. In: ENCONTRO NACIONAL DE ECONOMIA, 24., Anais. Campinas: ANPEC, 1996a, v. 1, p. 42-61.

FERNANDES, R. Mercado de trabalho não-regulamentado: participação relativa e diferenciais de salários. Pesquisa e Planejamento Econômico,. v. 26, n. 3, p. 417442, dez. 1996b.

PESQUISA MENSAL DE EMPREGO. Rio de Janeiro: FIBGE. (vários meses).

GERRY, C. Petty production and capitalist production in Dakar: the crisis of the selfemployed. World Development, v. 6, n. 9/10, 1978.

GREENE, W. Econometric analysis. Local: Macmillan, 1993.

HECKMAN, J. Sample selection bias as a specification error. In: SMITH, J. P. Female labor supply: theory and stimation. New Jersey: Princeton University Press, 1980. 
HILL, M. A. Female labor supply in Japan: implications of the informal sector for labor force participation and hours of work. The Journal of Human Resourses, p. 143$161,1989$.

KASSOUF, A. L.Determinants of the labor force participation and earnings in the formal and informal sectors. Piracicaba, ESALQ/USP,1997. (não publicado).

The wage rate estimation using the Heckman procedure. Revista de econometria, v. 14, n. 1, p. 89-107, April 1994.

LEE, L. F. Generalized econometric models with selectivity. Econometrica, v. 51, n. 2, p. 507-512, March 1983.

LOVELL, P. A. Raça, classe, gênero e discriminação salarial no Brasil. In:Estudos Afro-Asiáticos. n. 22, set. 1992, p. 85-98.

MADDALA, G. Limited-dependent and qualitative variables in econometrics. Cambridge: Cambridge Universit Press, 1990.

MARCOUILLER, D.; CASTILLA, V. R. de; WOODRUFF, C. Formal measures of the informal-sector wage gap in Mexico, El Salvador, and Peru. Economic Development and Cultural Change, v. 45, n. 2, p. 367-392, January 1997.

MINCER, J. Schooling, experience, and earnings. New York: Columbia University Press for the National Bureauof of Economic Research, 1974

MOSER, C. Informal petty comodity production: dualism or dependence in urban development. World Development, v. 6, n. 9/10, 1978. 
NUNURA CHULLY, J. B. Ajustamento e Informalidade no Mercado de Trabalho Peruano: 1950-1989. São Paulo, 1992. 430p. Tese (doutorado) - Faculdade de Economia, Administração e Contabilidade da Universidade de São Paulo.

PERO, V. L. A carteira de trabalho no mercado de trabalho metropolitano brasileiro. Revista de Estudos Sociais e Econômicos, v. 1, p. 159-196, 1994.

SAVEDOFF, W. The stability of regional wage diferentials in Brasil. Texto para Discussão. IPEA, n. 176, 1988

SILVA, S. C. Mec quer reduzir taxa de repetência para 15\%. O Estado de S. Paulo. São Paulo, 11 de jul. 1997, p. A-15.

SOUZA, P. R. de. Emprego, salários e pobreza. São Paulo: HUCITEC, 1980.

TIEFENTHALER, J. Female labor force participation and wage determination in Brazil, 1989. In: PSACHAROPOULOS, G.; TZANNATOS, Z. (Eds.) Cases studies on women's employmente and pay in Latin America, 1994.

URANI, A. Ajuste macroeconômico e flexibilidade do mercado de trabalho no Brasil 1981/95. Local: IPEA, 1996. (Texto para discussão, n. 380).

VALLE SILVA, N. O preço da cor: diferenciais raciais na distribuição da renda no Brasil. Pesquisa e Planejamento Econômico, v.10, n.1, p.21-44, 1980

VALLE SILVA, N. Situação social da população negra. In: VELLOSO, J.P.R. ; ALBUQUERQUE, R.C. (Eds.). Pobreza e Mobilidade Social. São Paulo: Editora Nobel, 1993. 


\section{BIBLIOGRAFIA RECOMENDADA}

AMADEO, E.; CAMARGO, J. M.; GONZAGA, G.; BARROS, R. e MENDONÇA, R. A natureza e o funcionamento do mercado de trabalho brasileiro desde 1980. Local: IPEA, 1994. (Texto para discussão, n. 353).

AZEVEDO, B. R. Z. de. A produção não capitalista: uma discussão teórica. Porto Alegre: FEE, 1985.

CAVALCANTE, C. Economia oculta, pequena produção, mercado informal ou circuito inferior: uma tentativa de precisar um conceito para o setor informal. Ciência e Cultura, v. 39, n. 5/6, maio/jun. 1987.

PINHO, D. B. Economia informal, tecnologia apropriada e associativismo. São Paulo, 1986.

REZENDE, G. B. C. de. Pequena empresa e o setor informal: uma análise das barreiras existentes ao livre crescimento e transição ao setor formal. Porto Alegre, 1989. Dissertação (Mestrado) - Faculdade de Economia da Universidade Federal do Rio Grande do Sul.

SABÓIA, J. Dualismo ou integração no mercado de trabalho? Estudos Econômicos, v. 19, n. esp., 1989.

SOTO, H de. Economia subterrânea: análise da realidade peruana. Rio de Janeiro: Globo, 1986. 
APÊNDICE 
Tabela A1. Média e desvios padrões para os homens.

\begin{tabular}{|c|c|c|c|c|c|c|c|c|c|c|c|c|c|c|c|c|c|c|}
\hline & \multicolumn{6}{|c|}{ Mercado de trabalho formal } & \multicolumn{6}{|c|}{ Mercado de trabalho informal } & \multicolumn{6}{|c|}{ Empregadores } \\
\hline & \multicolumn{2}{|c|}{ Branca } & \multicolumn{2}{|c|}{ Parda } & \multicolumn{2}{|c|}{ Preta } & \multicolumn{2}{|c|}{ Branca } & \multicolumn{2}{|c|}{ Parda } & \multicolumn{2}{|c|}{ Preta } & \multicolumn{2}{|c|}{ Branca } & \multicolumn{2}{|c|}{ Parda } & \multicolumn{2}{|c|}{ Preta } \\
\hline & média & d. $p$ & média & d. $p$ & média & d. p. & média & d. p. & média & d. p. & média & d.p. & média & d.p & média & d. p. & média & d. p. \\
\hline Escolaridade & 7,96 & 4,43 & 6,16 & 4,12 & 5,49 & 3,85 & 6,15 & 4,26 & 3,94 & 3,66 & 3,58 & 3,38 & 9,43 & 4,38 & 7,15 & 4,45 & 6,04 & 3,42 \\
\hline Experiência & 24,51 & 10,70 & 24,63 & 10,70 & 26,05 & 11,06 & 28,32 & 11,99 & 27,80 & 11,44 & 28,73 & 12,21 & 29,0 & 11,33 & 28,85 & 10,91 & 29,59 & 10,45 \\
\hline Experiência2 & 715,8 & 597,6 & 721,5 & 597,6 & 804,2 & 636,9 & 946,6 & 736,4 & 903,9 & 700,9 & 976,2 & 768,3 & 971,0 & 689,8 & 949,0 & 662,2 & 988,9 & 648,7 \\
\hline Educexp ${ }^{1}$ & 180,3 & 131,0 & 137,0 & 111,8 & 128,4 & 104,1 & 158,0 & 131,2 & 96,37 & 100,5 & 88,2 & 94,15 & 255,8 & 151,7 & 186,5 & 130,8 & 165,7 & 126,2 \\
\hline R. Norte & 0,019 & 0,18 & 0,076 & 0,31 & 0,013 & 0,13 & 0,032 & 0,22 & 0,119 & 0,37 & 0,033 & 0,22 & 0,024 & 0,19 & 0,12 & 0,37 & 0,091 & 0,35 \\
\hline R. Sul & 0,22 & 0,45 & 0,070 & 0,25 & 0,10 & 0,33 & 0,23 & 0,44 & 0,047 & 0,20 & 0,069 & 0,28 & 0,25 & 0,45 & 0,042 & 0,22 & 0,12 & 0,37 \\
\hline R. Sudeste & 0,63 & 0,50 & 0,450 & 0,46 & 0,68 & 0,50 & 0,55 & 0,49 & 0,29 & 0,41 & 0,57 & 0,50 & 0,57 & 0,50 & 0,30 & 0,41 & 0,57 & 0,49 \\
\hline R. C. Oeste & 0,51 & 0,28 & 0,085 & 0,25 & 0,45 & 0,25 & 0,068 & 0,31 & 0,10 & 0,34 & 0,038 & 0,23 & 0,070 & 0,31 & 0,14 & 0,39 & 0,038 & 0,24 \\
\hline S. Secundário & 0,39 & 0,48 & 0,37 & 0,32 & 0,37 & 0,48 & 0,25 & 0,43 & 0,30 & 0,46 & 0,38 & 0,48 & 0,25 & 0,43 & 0,31 & 0,45 & 0,52 & 0,50 \\
\hline S. Terciário & 0,58 & 0,49 & 0,59 & 0,48 & 0,58 & 0,49 & 0,64 & 0,48 & 0,50 & 0,50 & 0,44 & 0,50 & 0,63 & 0,48 & 0,56 & 0,49 & 0,45 & 0,50 \\
\hline Sindicato & 0,38 & 0,48 & 0,34 & 0,48 & 0,30 & 0,46 & 0,099 & 0,30 & 0,081 & 0,27 & 0,066 & 0,24 & 0,21 & 0,41 & 0,16 & 0,38 & 0,10 & 0,33 \\
\hline$n^{\circ}$ de observ. & 13.598 & & 8.473 & & 1.388 & & 10.441 & & 9.103 & & 1.114 & & 2.669 & & 865 & & 50 & \\
\hline
\end{tabular}

Termo de interação das variáveis escolaridade e experiência. 
Tabela A2. Média e desvios padrões para as mulheres'.

\begin{tabular}{|c|c|c|c|c|c|c|c|c|c|c|c|c|c|c|c|c|}
\hline & \multicolumn{6}{|c|}{ Mercado de trabalho formal } & \multicolumn{6}{|c|}{ Mercado de trabalho informal } & \multicolumn{4}{|c|}{ Empregadores } \\
\hline & \multicolumn{2}{|c|}{ Branca } & \multicolumn{2}{|c|}{ Parda } & \multicolumn{2}{|c|}{ Preta } & \multicolumn{2}{|c|}{ Branca } & \multicolumn{2}{|c|}{ Parda } & \multicolumn{2}{|c|}{ Preta } & \multicolumn{2}{|c|}{ Branca } & \multicolumn{2}{|c|}{ Parda } \\
\hline & média & d. $p$ & média & d. $\mathrm{p}$ & média & d. p. & média & d. p. & média & d. p. & média & d.p. & média & d.p & média & d. p. \\
\hline Escolaridade & 9,59 & 4,42 & 7,82 & 4,32 & 6,47 & 4,24 & 6,25 & 4,27 & 4,51 & 3,75 & 3,82 & 3,39 & 10,89 & 3,89 & 9,05 & 4,24 \\
\hline Experiência & 21,17 & 10,09 & 21,68 & 10,48 & 23,24 & 11,27 & 25,26 & 11,97 & 24,97 & 11,97 & 26,86 & 12,31 & 23,16 & 10,67 & 25,40 & 11,17 \\
\hline Experiência2 & 550,3 & 493,0 & 581,1 & 521,0 & 666,6 & 573,4 & 778,9 & 658,0 & 767,8 & 665,9 & 876,0 & 724,7 & 649,5 & 546,9 & 779,3 & 629,3 \\
\hline Educexp ${ }^{2}$ & 188,2 & 127,0 & 152,8 & 113,5 & 132,1 & 103,7 & 138,0 & 112,2 & 93,79 & 90,4 & 86,14 & 86,76 & 234,5 & 131,5 & 212,0 & 131,1 \\
\hline R. Norte & 0,025 & 0,21 & 0,088 & 0,33 & 0,010 & 0,12 & 0,027 & 0,21 & 0,094 & 0,34 & 0,020 & 0,16 & 0,019 & 0,18 & 0,12 & 0,36 \\
\hline R. Sul & 0,24 & 0,45 & 0,053 & 0,23 & 0,11 & 0,37 & 0,22 & 0,44 & 0,056 & 0,22 & 0,099 & 0,32 & 0,29 & 0,48 & 0,039 & 0,20 \\
\hline R. Sudeste & 0,57 & 0,50 & 0,42 & 0,46 & 0,69 & 0,50 & 0,57 & 0,49 & 0,321 & 0,42 & 0,59 & 0,50 & 0,53 & 0,49 & 0,31 & 0,41 \\
\hline R. C. Oeste & 0,56 & 0,29 & 0,089 & 0,33 & 0,035 & 0,23 & 0,059 & 0,29 & 0,091 & 0,32 & 0,033 & 0,21 & 0,053 & 0,28 & 0,066 & 0,28 \\
\hline S. Secundário & 0,15 & 0,35 & 0,14 & 0,34 & 0,15 & 0,34 & 0,068 & 0,25 & 0,053 & 0,22 & 0,043 & 0,20 & 0,19 & 0,39 & 0,12 & 0,34 \\
\hline S. Terciário & 0,84 & 0,36 & 0,85 & 0,35 & 0,84 & 0,35 & 0,92 & 0,28 & 0,090 & 0,28 & 0,92 & 0,26 & 0,78 & 0,41 & 0,85 & 0,36 \\
\hline Sindicato & 0,32 & 0,47 & 0,27 & 0,45 & 0,20 & 0,41 & 0,049 & 0,22 & 0,30 & 0,16 & 0,019 & 0,13 & 0,21 & 0,41 & 0,17 & 0,39 \\
\hline$n^{\circ}$ de observ. & 9.065 & & 4.974 & & 864 & & 7.383 & & 6.104 & & 882 & & 743 & & 169 & \\
\hline
\end{tabular}

As médias e desvios padrões para as mulheres para as mulheres pretas empregadoras não foram calculadas por não ter sido possível estimar a sua equação de rendimentos, devido à insuficiência da amostra (apenas 8 mulheres pretas empregadoras).

${ }^{2}$ Termo de interação das variáveis escolaridade e experiência. 
Tabela A3. Funções de Rendimentos para homens e mulheres, de cor branca, nos mercados de trabalho formal e informal e para empregadores.

\begin{tabular}{|c|c|c|c|c|c|c|}
\hline \multirow[b]{2}{*}{ Variáveis } & \multicolumn{3}{|c|}{ Homem } & \multicolumn{3}{|c|}{ Mulher } \\
\hline & Formal & Informal & Empregadores & Formal & Informal & Empregadores \\
\hline \multirow[t]{2}{*}{ Constante } & $-2,15$ & $-2,35$ & 2,23 & $-2,64$ & $-1,75$ & 2,10 \\
\hline & $(-21,18)^{* * *}$ & $(-22,53)^{* * *}$ & $(4,26)^{* * *}$ & $(-19,48)^{* * *}$ & $(-11,85)^{* * *}$ & $(2,17)^{* *}$ \\
\hline \multirow[t]{2}{*}{ Lambda } & 0,498 & 1,326 & $-0,860$ & 0,496 & 0,175 & $-0,550$ \\
\hline & $(9,27)^{* * *}$ & $(14,81)^{* * *}$ & $(-5,84)^{* * *}$ & $(11,96)^{* * *}$ & $(2,53)^{* *}$ & $(-2,48)^{* *}$ \\
\hline \multirow[t]{2}{*}{ Escolaridade } & 0,160 & 0,0570 & 0,0633 & 0,186 & 0,133 & 0,0683 \\
\hline & $(38,78)^{* * *}$ & $(9,02)^{* * *}$ & $(3,58)^{* * *}$ & $(35,05)^{* * *}$ & $(22,76)^{* * *}$ & $(2,02)^{* *}$ \\
\hline \multirow[t]{2}{*}{ Experiência } & 0,0553 & 0,0477 & 0,0160 & 0,0615 & 0,0365 & $-0,0331$ \\
\hline & $(15,71)^{* * *}$ & $(11,90)^{* * *}$ & $(1,32)$ & $(13,00)^{* * *}$ & $(5,82)^{* * *}$ & $(-1,41)$ \\
\hline Experiência ao & $-0,000755$ & $-0,000551$ & $-0,000184$ & $-0,000835$ & $-0,000387$ & 0,000923 \\
\hline quadrado & $(-13,46)^{* * *}$ & $(-10,02)^{* * *}$ & $(-1,31)$ & $(-10,73)^{* * *}$ & $(-4,37)^{* * *}$ & $(3,04)^{* * *}$ \\
\hline Escolaridade * & $-0,000417$ & 0,000241 & $-0,000698$ & $-0,00109$ & $-0,00138$ & $-0,000562$ \\
\hline Experiência & $(-3,06)^{* * *}$ & $(1,40)$ & $(-1,73)^{*}$ & $(-6,70)^{* * *}$ & $(-6,00)^{* * *}$ & $(-0,61)$ \\
\hline \multirow[t]{2}{*}{ Região Norte } & 0,162 & 0,310 & $-0,0562$ & 0,291 & 0,285 & 0,285 \\
\hline & $(3,66)^{* * *}$ & $(6,31)^{* * *}$ & $(-0,45)$ & $(6,28)^{* * *}$ & $(4,58)^{* * *}$ & $(1,11)$ \\
\hline \multirow[t]{2}{*}{ Região Sul } & 0,300 & 0,0545 & 0,0273 & 0,302 & 0,272 & $-0,0143$ \\
\hline & $(12,57)^{* * *}$ & $(1,74)^{*}$ & $(0,39)$ & $(12,10)^{* * *}$ & $(7,86)^{* * *}$ & $(-0,11)$ \\
\hline \multirow[t]{2}{*}{ Região Sudeste } & 0,452 & 0,156 & 0,219 & 0,410 & 0,457 & 0,305 \\
\hline & $(19,72)^{* * *}$ & $(5,06)^{* * *}$ & $(3,47)^{* * *}$ & $(18,26)^{* * *}$ & $(15,25)^{* * *}$ & $(2,65)^{* * *}$ \\
\hline Região Centro & 0,336 & 0,146 & 0,0282 & 0,350 & 0,182 & $-0,0554$ \\
\hline Oeste & $(10,71)^{* * *}$ & $(3,85)^{* * *}$ & $(0,32)$ & $(10,12)^{* * *}$ & $(3,91)^{* * *}$ & $(-0,32)$ \\
\hline Setor & 0,472 & 0,483 & 0,0841 & 0,306 & 0,275 & $-0,0336$ \\
\hline secundário & $(13,49)^{* * *}$ & $(16,48)^{* * *}$ & $(1,36)$ & $(3,94)^{* * *}$ & $(3,39)^{* * *}$ & $(-0,15)$ \\
\hline Setor & 0,317 & 0,501 & 0,142 & 0,213 & 0,365 & 0,00571 \\
\hline terciário & $(9,10)^{* * *}$ & $(18,40)^{* * *}$ & $(2,53)^{* *}$ & $(2,79)^{* * *}$ & $(4,98)^{* * *}$ & $(0,03)$ \\
\hline Filiação trabalhador & 0,220 & 0,245 & 0,233 & 0,242 & 0,435 & 0,370 \\
\hline à sindicato & $(18,88)^{* * *}$ & $(9,12)^{* * *}$ & $(5,41)^{* * *}$ & $(16,47)^{* * *}$ & $(9,78)^{* * *}$ & $(4,50)^{* * *}$ \\
\hline$\overline{\mathrm{R}^{2}}$ & 0,50 & 0,34 & 0,21 & 0,49 & 0,29 & 0,19 \\
\hline teste $F$ & $1.131,80^{* * *}$ & $453,43^{* * *}$ & $59,26^{* * *}$ & $722,92^{* * *}$ & $256,21^{* * *}$ & $14,87^{* * *}$ \\
\hline $\mathrm{n}^{\circ}$ de observações & 13.598 & 10.441 & 2.669 & 9.065 & 7.383 & 743 \\
\hline
\end{tabular}

As estatísticas-t são dadas entre parênteses abaixo dos coeficientes.

* Significativo ao nível de $10 \%$

** Significativo ao nivel de $5 \%$

*** Significativo ao nivel de $1 \%$ 